\title{
COMPARING THE DEMOGRAPHICS OF TWO STEELHEAD POPULATIONS AND THEIR HABITAT CHARACTERISTICS
}

\author{
A Thesis Presented to the \\ Biological Sciences Faculty \\ California Polytechnic State University \\ San Luis Obispo, CA \\ In Partial Fulfillment \\ Of the Requirements for the Degree \\ Master of Science in Biological Sciences
}

By

Eileen Ann Baglivio

March 2012 
Copyright @ 2012

Eileen Ann Baglivio

ALL RIGHTS RESERVED 


\section{COMMITTEE MEMBERSHIP}

TITLE

Comparing the Demographics of Two Steelhead Populations and Their Habitat Characteristics

AUTHOR: $\quad$ Eileen Ann Baglivio

DATE SUBMITTED: March 2012

Royden Nakamura, PhD

Raysen Neteamura

Biological Sciences Department, Cal Poly

Jennifer Nelson

Cennyer Reloca

California Department of Fish and Game

John D. Perrine, PhD

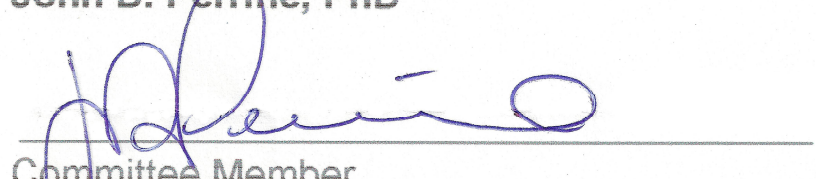

committed Member

Biplogical Sciences Department, Cal Poly

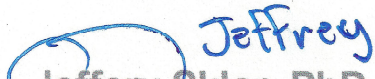

Jeffery sklar, PhD

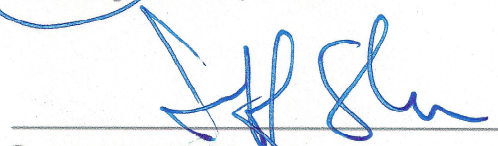

Committee Menber

Statistics Department, Cal Poly 


\begin{abstract}
Comparing the Demographics of Two Steelhead Populations and

Their Habitat Characteristics

Eileen Ann Baglivio
\end{abstract}

Currently, little is known about the demographics of the Oncorhynchus mykiss irideus, or steelhead trout, populations in San Luis Obispo County. Specifically, demographic information including length, age, and condition when first leaving a watershed for the open ocean is lacking. This thesis takes a closer look at a biological and environmental data collected by the California Department of Fish and Game Central Coast Steelhead and Coho Salmon project under the direction of Associate Biologist Jennifer Nelson. The main goal of this thesis is to analyze demographic and habitat data from the steelhead populations of two northern San Luis Obispo county coastal streams, San Simeon and Santa Rosa Creeks.

Habitat mapping surveys were conducted on each stream in order to identify suitable habitat for various steelhead life stages. The data generated from the habitat mapping surveys was compared between the two creeks over the two different survey years (1993 and 2005). The results of these surveys showed that habitat types have changed on San Simeon Creek between survey years while Santa Rosa Creek appeared to remain the same.

Biological inventory methods were conducted on the populations of $O$. m. irideus in San Simeon and Santa Rosa Creeks during the years of 1993 and 2005. There were very few observations of steelhead moving downstream on both survey creeks in 
1993. During the 2005 out-migrant trapping season, the data revealed that nonsmolting fish are moving downstream in the watershed in addition to smolting fish. There is evidence that age $1+$ and $2+$ fish make up the majority of downstream migrants. Older, larger fish tend to migrate downstream earlier in the trapping season. Fork length - weight relationships are not significant between steelhead sampled from out-migrant traps, while those sampled throughout the watersheds by means of electrofishing were different between creeks. Percent frequency distribution of electrofished steelhead reveal that steelhead sampled in 2005 have a similar distribution of total lengths between creeks, where as those sampled in 1993 have a slightly different distribution from each other.

Further analysis of steelhead scales sampled from the populations on San Simeon and Santa Rosa Creeks in 2005 gave greater insight into the growth of these fish. In most cases, steelhead from Santa Rosa Creek have greater growth increments and higher circuli counts per annuli than those surveyed from San Simeon Creek. The majority of scale samples analyzed showed growth since the last annuli mark suggesting an increase in growth over the winter months. The average number of circuli to the first annuli is significantly different between watersheds, as is the relationship between fork length and scale radius.

Analyzing steelhead demographics is important to understanding the life history pattern of steelhead in the South Central California Coast Distinct Population Segment (DPS). Surveys that monitor environmental conditions and habitat help to identify potential limiting factors and risks to steelhead populations. The results of this thesis 
present such data in hopes to promote continued research and efficient management practices of steelhead trout populations in San Luis Obispo County. 


\section{ACKNOWLEDGMENTS}

For the past several years of my life, steelhead trout have been a key variable in the life history patterns I have chosen. I am grateful to Dr. Royden Nakamura for giving me knowledge and guidance throughout my graduate career. He has helped me grow from a wayward fry into a smolt, ready to take on new environments. Mahalo nui loa!

I was very lucky to receive employment with the California Department of Fish and Game Central Coast Steelhead and Coho Salmon Project, under the supervision of Associate Biologist, Jennifer Nelson. Not only do I thank Jennifer for the use of the data we collected for my thesis, but she has been an influential mentor and friend throughout this process.

There are many additional individuals that have offered their time and expertise throughout this process. Dr. John Perrine has been a great contributor to the success of this document; I appreciate all the time spent helping me achieve this goal. I am grateful for the assistance I received from Dr. Jeff Sklar; offering much needed time to help me finish this thesis. Thank you to my fellow fish whisperer, Timothy Kahles, whose help in the field and moral support were invaluable. I am very appreciative of Terry Jackson and the Steelhead Report Card who provided the grant opportunities to continue this much needed research on steelhead trout populations. I am grateful to Rob Titus and his lab for assistance in teaching me about the nuances of steelhead scale analysis and aging. Thank you to all my friends that have helped me achieve my educational and professional goals by providing learning opportunities and unique fisheries experiences throughout California. 
I am very thankful for my friends and family who have kept me afloat while swimming upstream: Megan, Kerry, and Christine Baglivio, Patricia Knight, Peter A. Randall, Kristen J. Sanchez, and the Smith-Hatfield family just to name a few. A special thank you goes out to my parents, Stephen and Eileen Baglivio, for their unconditional love and support. 
Committee Membership ................................................................... iii

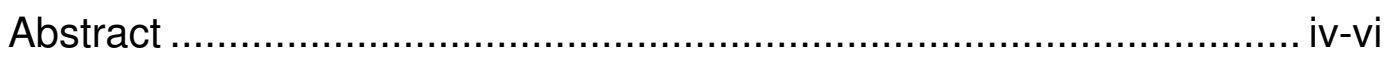

Acknowledgements ..................................................................... vii-viii

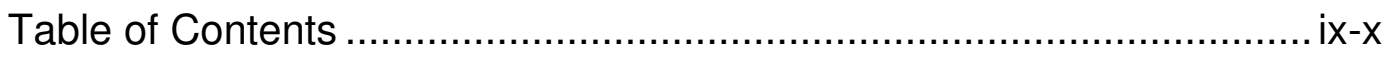

List of Tables ........................................................................... $\mathrm{xi}$

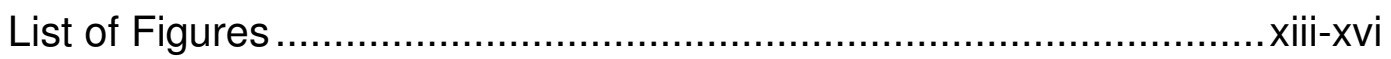

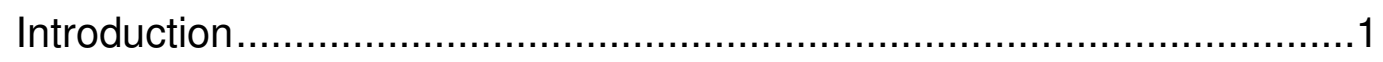

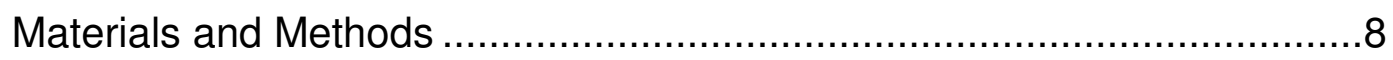

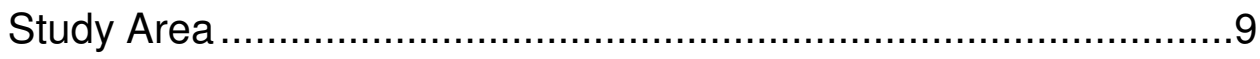

Precipitation and Water Temperature …...................................11

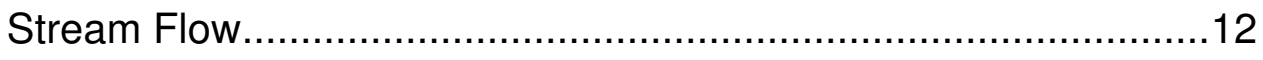

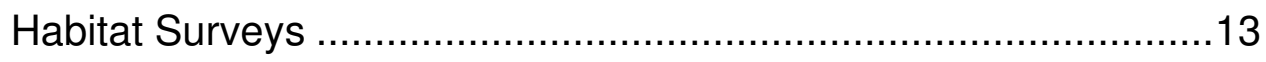

Out-migrant Trapping.......................................................... 14

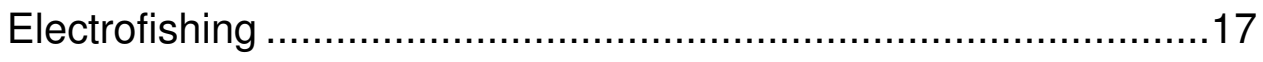

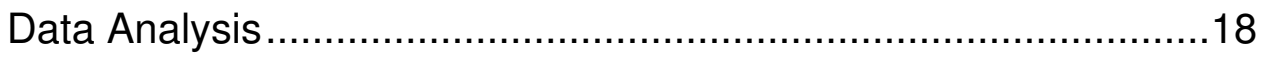

Age Determination and Scale Analysis ......................................19

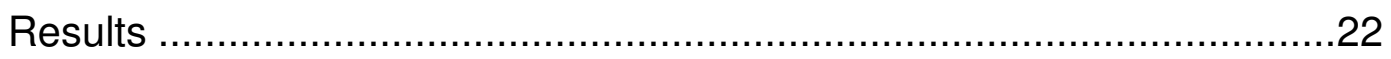

Precipitation and Water Temperature ........................................22

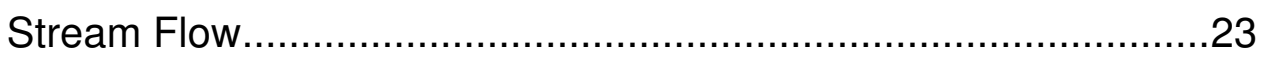

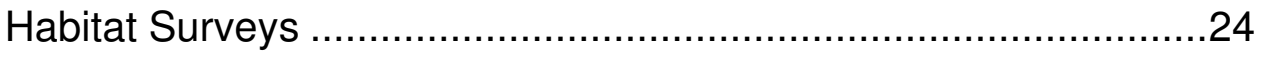

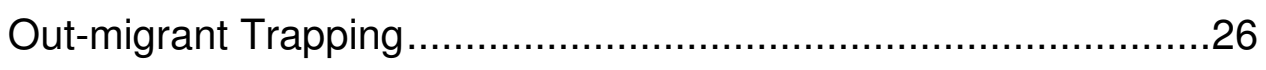




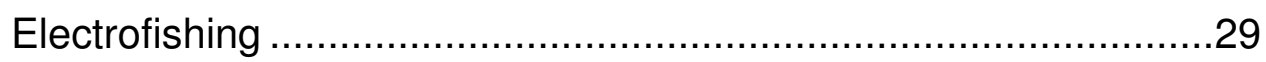

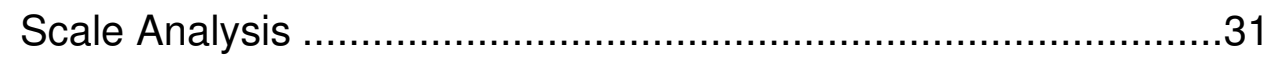

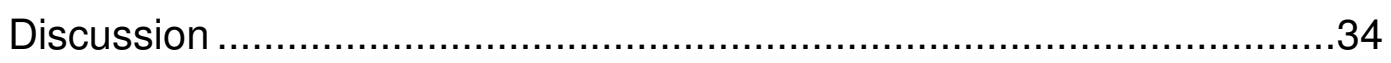

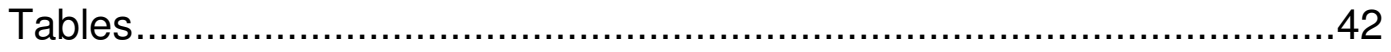

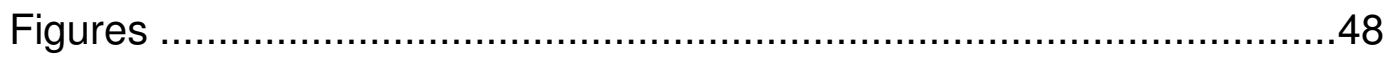

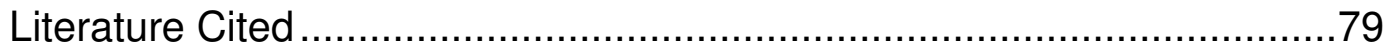




\section{LISTS OF TABLES}

Table

Page

1. Locations of electrofishing sites on San Simeon and Santa Rosa Creeks, 2005 ..... 42

2. Multiple regression analysis for fork length/weight relationship of steelhead caught in out-migrant traps on San Simeon and Santa Rosa Creeks in 2005.

3. Demographic data of steelhead caught in out-migrant traps on San Simeon and Santa Rosa Creeks, 2005

4. Growth increments of aged steelhead caught in out-migrant traps on San Simeon and Santa Rosa Creeks, 2005

5. Demographic data of steelhead caught by means of electrofishing on San Simeon and Santa Rosa Creeks, 2005

6. Multiple regression analysis for fork length/weight relationship of steelhead caught by means of electrofishing on San Simeon and Santa Rosa Creeks in 2005.

7. Multiple regression analysis for fork length versus scale radius (at $90^{\circ}$ and $45^{\circ}$ ) from steelhead caught in out-migrant traps on San Simeon and Santa Rosa Creeks in 2005

8. Circuli counts for age $1+, 2+$, and $3+$ steelhead caught in out-migrant traps on San Simeon Creek and Santa Rosa Creek in 2005.

9. Two Sample T-test comparing the mean number of circuli to the first annuli of age $1+$ steelhead scales sampled along the $90^{\circ}$ radius line from San Simeon and Santa Rosa Creeks

10. Two Sample T-test comparing the mean number of circuli to the first annuli of age $1+$ steelhead scales sampled along the $45^{\circ}$ radius line from San Simeon and Santa 
Rosa Creeks

11. Two Sample T-test comparing the mean number of circuli to the first annuli of age $1+$ steelhead scales sampled along the $45^{\circ}$ and $90^{\circ}$ radius lines from San Simeon Creek.

12. Two Sample T-test comparing the mean number of circuli to the first annuli of age $1+$ steelhead scales sampled along the $45^{\circ}$ and $90^{\circ}$ radius lines from Santa Rosa Creek. 


\section{LIST OF FIGURES}

Figure

Page

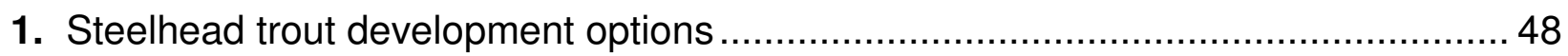

2. South-Central and Southern California Coast Steelhead ESUs ............................. 49

3. Watershed delineations, stream flow site locations, and trap locations for San

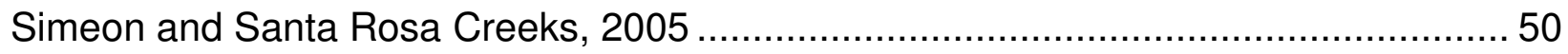

4. Out-migrant fyke net and weir setup on San Simeon Creek from

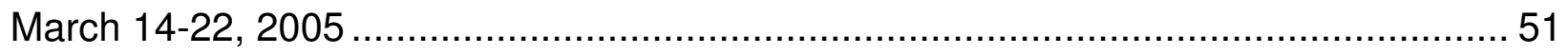

5. Out-migrant fyke net and weir setup on San Simeon Creek from April 14 to June 8, 2005

6. Out-migrant fyke net and weir setup on Santa Rosa Creek from April 18 to May 25, 2005

7. Image of an O. m. irideus scale used to interpret age

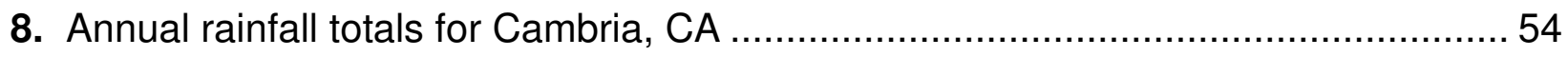

9. Precipitation amounts for Cambria, CA during the 1992-93 rain season.................. 55

10. Precipitation amounts for Cambria, CA during the $2004-05$ rain season................55

11. Average daily temperature with max and min range at three different sites on Santa Rosa Creek from June 2 to Oct. 25, 2005.

12. Stream flow measurements for San Simeon and Santa Rosa Creeks during the 1993 field season

13. Stream flow measurements for San Simeon and Santa Rosa Creeks during the 2005 field season 
14. Percent frequency distribution of units identified during stream habitat mapping surveys on San Simeon and Santa Rosa Creek in 1993

15. Percent frequency distribution of units identified during stream habitat mapping surveys on San Simeon $(\mathrm{N}=87)$ and Santa Rosa Creek $(\mathrm{N}=857)$ in 2005

16. Percent frequency distribution of habitat units observed on San Simeon Creek in $1993(\mathrm{~N}=128)$ and $2005(\mathrm{~N}=87)$

17. Percent frequency distribution of habitat units observed on Santa Rosa Creek in $1993(\mathrm{~N}=1018)$ and $2005(\mathrm{~N}=857)$

18. The total length frequency distribution of steelhead caught in the out-migrant traps on San Simeon and Santa Rosa Creeks during the 1993 field season..... 60

19. The percent frequency distribution of total lengths of steelhead caught in the outmigrant traps on San Simeon and Santa Rosa Creeks during the 1993 field season.

20. The fork length frequency distribution of steelhead caught in the out-migrant traps on San Simeon and Santa Rosa Creeks during the 2005 field season......

21. The percent frequency distribution of fork lengths of steelhead caught in the outmigrant traps on San Simeon and Santa Rosa Creeks during the 2005 field

22. The average fork length of steelhead caught in out-migrant traps on San Simeon and Santa Rosa Creeks during the 2005 field season

23. Scatterplot of the natural log of fork lengths versus the natural log of weights for steelhead caught in the out-migrant trap on San Simeon and Santa Rosa Creeks in 1993

24. Scatterplot of the natural log of fork lengths versus the natural log of weights for 
fish caught in the out-migrant trap on San Simeon Creek in 2005

25. Scatterplot of the natural log of fork lengths versus the natural log of weights for fish caught in the out-migrant trap on Santa Rosa Creek in 2005 65

26. Distribution of steelhead condition factors ( $k$ ) by date trapped on San Simeon and Santa Rosa creeks, 2005 66

27. Fork lengths of parr, partial smolt, and smolt captured on San Simeon Creek throughout the trapping season in 2005 67

28. Fork lengths of parr, partial smolt, and smolt captured on Santa Rosa Creek throughout the trapping season in 2005 68

29. The natural log of fork length by the natural log of weight for age $0+, 1+, 2+$ steelhead trapped on San Simeon Creek, 2005. 69

30. The natural log of fork length by the natural log of weight for age $1+, 2+$ steelhead trapped on Santa Rosa Creek, 2005. 70

31. Fork length by date distribution of age $0+, 1+, 2+, 3+$ steelhead caught on San Simeon Creek in 2005. 71

32. Fork length by date distribution of age $1+, 2+$ steelhead caught on Santa Rosa Creek in 2005 72

33. Total length distribution of steelhead electrofished from San Simeon and Santa

Rosa Creeks in 1993. 73

34. The percent frequency distribution of total lengths of steelhead electrofished from San Simeon and Santa Rosa Creeks in 1993 73

35. Total length distribution of steelhead electrofished from San Simeon and Santa Rosa Creeks in 2005. 
36. The percent frequency distribution of total lengths of steelhead electrofished from San Simeon and Santa Rosa Creeks in 2005

37. Fork length distribution of steelhead electrofished from San Simeon and Santa Rosa Creeks in 2005

38. Percent frequency distribution of fork length of steelhead electrofished from San Simeon and Santa Rosa Creeks in 2005

39. Scatterplot/regression analysis fork length and weight of steelhead electrofished on San Simeon and Santa Rosa Creeks, 2005

40. Scatterplot/regression analysis of scale radius measurements at the 90 and 45 degree angles versus fork length for age $0+, 1+, 2+$ steelhead caught on San Simeon Creek, 2005

41. Scatterplot/regression analysis of scale radius measurements at the 90 and 45 angles versus fork length for and 1+ and 2+ steelhead caught on Santa Rosa Creek, 2005 


\section{INTRODUCTION}

The species Oncorhynchus mykiss irideus is commonly known as coastal rainbow trout or steelhead trout (Behnke, 1992). I will refer to this species as steelhead in this paper. This fish utilizes coastal waterways along the Pacific Coast of North America, including many watersheds in San Luis Obispo County (NMFS-SWR, 2007; Moyle, 2002). Unfortunately, steelhead trout in this area are currently listed as a threatened species (NMFS-SWR, 2007). Land development resulting in pollution, sedimentation, and decreased water flow due to human residential, agricultural, and industrial needs has impacted the habitat utilized by this species (NMFS-SWR, 2007). The effects of a growing and expanding human population are currently detrimental to the survival of steelhead. Research must be conducted to better understand the current status of these populations in this geographical area in order to implement more relevant management and restoration plans.

Currently, little is known about the demographics of the steelhead trout populations in San Luis Obispo County. Specifically, demographic information including length, age, and condition of steelhead migrating to the open ocean is lacking. Biological and environmental information about this species was collected by the California Department of Fish and Game in 1993 and 2005 on two watersheds in Cambria, California (Nelson, 1994, 1995, 2009a, 2009b). The data generated from these projects is analyzed in this study to gain insight into the steelhead populations of San Simeon and Santa Rosa Creeks.

Steelhead trout can be found along the coastal watersheds of North America from Alaska to Baja California (Moyle, 2002). This species can spend a varying amount 
of time in freshwater systems such as rivers or creeks. The individuals that remain in freshwater habitat throughout their life cycles are generally referred to as resident rainbow trout. The term "steelhead" is given to those individuals of this species that exhibit anadromous behavior and migrate to the ocean before returning as mature adults to reproduce in a freshwater system.

There are several different life history patterns that steelhead can exhibit. Three general options have been described (NMFS-SWR, 2007), with variations of time spent in different microhabitats. These include a completely freshwater existence, a completely anadromous life history, or a modified pattern with saltwater existence localized in a coastal lagoon or estuary setting (NMFS-SWR, 2007, Boughton et al., 2006) (Figure 1). The third life history option refers to steelhead migration downstream to an estuary or lagoon before possibly migrating back upstream the same system or to the ocean (Hayes et al., 2008; Bond et al., 2008). There are as many as 32 life history paths that an individual O. m. irideus can take to reach maturity (Thorpe, 1998). This correlates to earlier data presented by Shapovalov and Taft (1954). This number is generated when including the varying number of years an individual can spend in a freshwater and marine environment before becoming mature (Thorpe, 1998).

Steelhead trout are iteroparous, meaning that unlike entirely anadromous Pacific salmon; they can reproduce more than once in their lifetime (Busby et al., 1996; NMFSSWR, 2007). Females create nests, or redds, by moving gravel and small cobble sized substrate with her caudal fin to make a depression in the creek substrate in which to lay her eggs (Shapovalov and Taft, 1954; Moyle, 2002; NMFS-SWR, 2007). Redds are frequently located in areas of good water flow, such as at pool tail crests (the point 
where water flow increases as it leaves a pool) and in riffles (Titus et al., in draft; Briggs, 1953). A male fertilizes the eggs as they are being deposited by the female. The female will then cover the eggs with substrate and possibly move on to create more redds (NMFS-SWR, 2007). Here, the eggs are left to develop until they lose their casing and become alevin, a juvenile trout with a yolk sac still attached (Shapovalov and Taft, 1954). Alevin can spend two to three weeks in the gravel before the yolk sac is reabsorbed and the fish enter the water column as fry (Shapovalov and Taft, 1954; Moyle, 2002). Still quite small in size, the fry tend to inhabit faster moving creek habitat, such as runs and riffles (Moyle, 2002; Spina, 2003). The juvenile stages continue with the parr life stage. The term "parr" refers to the presence of dark colored vertical bands along the lateral sides of the trout body known as parr marks (Moyle, 2002).

Physical appearance of adults varies depending on the life history pathway. Resident rainbow trout retain their dark colored parr marks, speckled appearance, and exhibit an array of colors such as a pink or red lateral band (Moyle, 2002). The adults typically reside in habitats with lower flow velocity and deeper water depths rather than shallower, faster moving sections of creek (Spina, 2003). This habitat can provide protection with deep scour sections, root wads, and undercut banks.

Steelhead undergo a series of physiological and morphological changes to prepare for an ocean existence (Hoar, 1988). This involves a smoltification process as they migrate downstream and adapt to more saline conditions. During this process, the trout will change their bright colored rainbow appearance into a more silvery form, with a loss of parr marks and speckled appearance (Hoar, 1988). The "smolts" become more streamlined and develop a greater fork of their caudal fin with dark markings on the tips 
(Quinn, 2005). Physiologically, they must also adapt to saline conditions by regulating the transport of sodium, potassium, and chloride ions in and out of their body to maintain homeostasis (Hoar, 1988). Steelhead can spend a varying number of years (approximately one to two years) in the ocean before returning to freshwater, growing large (adding around 10 to $40 \mathrm{~cm}$ ) with increased food availability in the marine environment (Moyle, 2002).

Adult steelhead return to their original or natal creeks to spawn (Shapovalov and Taft, 1954). The timing of these spawning runs varies depending on the source of high stream flows. In central coastal California, increased stream flow due to heavy rain events break though sand bars at the confluence with the ocean allowing access to rivers and creeks (Titus et al., in draft). During this time, returning, mature steelhead adults swim upstream to find suitable spawning sites and available partners. Thus, they are termed winter-run steelhead.

Steelhead have been a part of the history of San Luis Obispo County for thousands of years. Historic records of remains found in Native American middens show that steelhead trout were a part of the aboriginal lifestyle although they were rarely observed in the middens sampled (Gobalet and Jones, 1995). Beginning in the 1930's, reports of fish stocking and fishing activities in some of the county's coastal watersheds were documented by the California Department of Fish and Game (Titus et al., in draft). Unfortunately, scientific research on the actual population sizes or the demographics of steelhead is limited in this area (Moyle et al., 2008). Most of the reports focus on population densities and the proposed population sizes of steelhead that can be 
supported within individual creeks (Titus et al., in draft). This information is valuable, but leaves much unknown about the steelhead populations in San Luis Obispo County.

Salmonid populations have greatly decreased over the last 150 years (Titus et al., in draft). Steelhead in San Luis Obispo County are currently listed as threatened under the Federal Endangered Species Act of 1973 (Boughton, 2006). They are part of the South-Central California Coast Steelhead Distinct Population Segment (DPS) and Environmentally Significant Unit (ESU) (Busby et al., 1996; NMFS-SWR, 2007). This DPS and ESU delineation includes anadromous populations from the Pajaro River, a tributary to the Monterey Bay, down to but not including the Santa Maria River in northern Santa Barbara County (Busby et al., 1996). San Luis Obispo County is located at the very southern portion of the South-Central ESU. Steelhead south of the Santa Maria River are part of the Southern California Coast Steelhead ESU which are listed as endangered. Refer to figure 2 for a map outlining these ESUs.

The focus of this study is on the life history phases of $O . m$. irideus that occur in freshwater and estuarine conditions, specifically coastal creek habitat. The coast of San Luis Obispo County is subject to warm dry summers with little or no precipitation and wet winters with flash flood conditions during periods heavy rain (as cited in NOAASWR, 2007). During the summer months, stream depth and flow commonly decrease significantly, eliminating potential rearing habitat and preventing down or upstream movement. As stream flow decreases and winter waves no longer contribute to changing beach topography, a sand bar can form at the confluence of the stream mouth and the ocean (Busby et al., 1996). The sand bars isolate the creek mouth and form an estuarine backwater zone called a lagoon which serves as a potential rearing nursery 
habitat for juvenile steelhead (Bond et al., 2008, Hayes et al., 2008). Sand bars commonly disconnect surface flow to the ocean, thus blocking the migration of fish in or out of the creek system (Busby et al., 1996).

Santa Rosa and San Simeon Creeks are two streams located in northern San Luis Obispo County, along the coast of central California. These creeks were selected as study sites because they both contain established steelhead populations in a region at risk for development (J. Nelson pers. comm., 2008). Land use practices present in these watersheds include urbanization, agriculture development, livestock grazing, and various forms of mining (Titus et al., in draft). These impacts cause sedimentation, degraded riparian habitat, decrease or loss of stream flow, and organic and urban pollution that directly and negatively affect these populations.

Evidence of human influence on creek habitat through the loss of a riparian zone has been observed throughout the range of steelhead trout. A riparian zone, or protective vegetation layer between stream habitats and the surrounding land, is composed of hydrophilic and water tolerable vegetation that will filter contaminants, supply food in the form of invertebrates, regulate temperatures in and around the creek, and stabilize stream banks (Platts, 1979). Insufficient riparian vegetation cover can cause the stream temperatures to increase with direct exposure to the sun, creating sub-optimal microhabitat conditions (as cited in Reiser and Bjornn, 1979). There would also be no influx of vegetation and brush material into the stream channel that juveniles and adults use as cover for protection.

In addition to riparian habitat, there are particular attributes of a creek system that are important to different life stages of $O$. m. irideus. Some of these features 
include sufficient amount and type of substrate, adequate water flow, and suitable water temperature (Reiser and Bjornn, 1979). Stream bank disturbances by grazing cattle can lead to erosion that creates an influx of fine soil into the watershed downstream (Platts, 1979). Fine sediment covers and infiltrates gravel and cobble, preventing oxygen rich water from flowing through the substrate to aerate developing steelhead embryos (Platts, 1979). Substrate size not only plays a role with early life stages of salmonids, but it affects the stream velocity and aquatic insect populations which directly affect the juveniles and adults (Reiser and Bjornn, 1979). Spina (2003) observed that steelhead utilize different parts of the stream habitat, partly due to stream flow velocities. Excessive groundwater pumping and instream diversions decrease water flow resulting in decreased food availability and depleting aquatic habitat. Temperature plays an important role in the various life stages of this species. Temperature extremes on both ends of the spectrum can be lethal for all life stages of steelhead and affect behavior, metabolic processes, and cause developmental problems (Reiser and Bjornn, 1979).

Fisheries biologists in San Luis Obispo County recognize the need for research to actively protect the O. m. irideus populations in this area (J. Nelson, pers. comm., 2008). Efforts to protect and increase steelhead populations and their habitat begin with obtaining valuable information about the populations of the steelhead in this area as well as thorough documentation of the habitat conditions and the factors that limit these populations. This project analyzes biological and environmental data for two steelhead populations within the county from two different survey years. 
The primary goal of this project is to identify similarities and differences between the demographics and habitat of steelhead trout populations from San Simeon and Santa Rosa Creeks in northern coastal San Luis Obispo County. Biological data was collected from juveniles migrating downstream and compared between the two watersheds. Differences in information such as age, length/weight relationships, and migration timing was used to characterize the two populations. In particular, the age and size of individual fish migrating downstream to the lagoon or ocean is important to answering questions about the life history juvenile steelhead in these watersheds. Data gathered on $O$. m. irideus throughout the creek systems was also studied to gain insight into the non-migrating populations.

Additionally, physical habitat information gathered through extensive stream surveys was analyzed. The frequency and physical attributes (e.g. length) of each habitat type was examined for both creeks. Habitat data that directly relates to particular life history stages, such as water temperature and stream flow, was also obtained. Particular habitat and environmental attributes were associated with the demographic information of these two populations.

\section{MATERIALS AND METHODS}

Data collected in 2005 on the O. m. irideus populations and habitat of San Simeon and Santa Rosa Creeks are the main focus of this study. A similar set of information was collected in 1993 but this data will only be used in supplemental comparisons. The 1993 survey year was also the first year of significant precipitation 
after a seven year drought that lasted from 1986 to 1992 . As a result, the number of migrating steelhead from these watersheds was limited.

\section{Study Sites}

San Simeon Creek is located in Cambria, California. This creek is a tributary to the Pacific Ocean with the headwaters in the Santa Lucia Mountain Range. The confluence of San Simeon Creek and the Pacific Ocean is at N35 ${ }^{\circ} 35^{\prime} 42.0^{\prime \prime}, \mathrm{W} 121^{\circ} 07^{\prime}$ 35.0". The mainstem of this creek is 6.7 miles $(10.8 \mathrm{~km})$ in length with a few significant tributaries (Van Gordon and Steiner Creeks) making this creek a third order stream (Figure 3). San Simeon Creek drains an area of 32.1 sq. miles (83 sq km) (Becker et al., 2010). The lower watershed consists of a willow riparian zone turning to mixed hardwood forests with increasing elevation. Grass and oak woodlands are observed in some of the highest elevations. There is a boulder falls measured at approximately 8 feet $(2.4 \mathrm{~m})$ high located at stream mile $5.7(9.2 \mathrm{~km})$. The falls usually prevents upstream migration, although it has been noted that this barrier is passable to adult steelhead during high flows (Titus et al., in draft). Periods of low flow and dry reaches during summer and early fall months have been documented on this creek since the early 1930's (Titus et al., in draft).

While the lowest $20 \%$ of the watershed is owned by State Parks as a recreation and preservation area, the remainder of the watershed is currently privately owned with varying land use practices (Nelson, 2009a). Some of these land use practices include a gravel mining operation and cattle grazing. Various mining operations in this watershed caused heavy erosion contributing to sedimentation and loss of riparian vegetation 
(Titus et al., in draft). Cattle grazing has been reported in this watershed as an impact to O. m. irideus habitat since 1973 (Titus et al., in draft). During the 2005 survey, Nelson observed the presence of nonnative invasive plant species in the riparian corridor (2009a). The CA Department of Fish and Game documented a few steelhead stocking events on San Simeon Creek in the first half of the $20^{\text {th }}$ century (Titus et al., in draft).

Santa Rosa Creek is located in Cambria, California, south of the San Simeon watershed. This mainstem of this creek continues upstream from the Pacific Ocean for 15 miles $(24.1 \mathrm{~km})$ with the headwaters located in the Santa Lucia Mountain Range (Figure 3). The confluence with the Pacific Ocean is located at N35 ${ }^{\circ} 34^{\prime} 07.0^{\prime \prime}, \mathrm{W} 121^{\circ}$ 06' 38.1". Santa Rosa Creek has a watershed area of 47 sq. miles (121.7 sq km) (Duff, 2007). Perry and Curti Creeks are two of the major tributaries in this system. This creek is characterized as third order stream (Nelson, 2009b). The riparian zone consists of willow vegetation at low elevations in the watershed followed by mixed hardwood forests at intermediate elevations. Grassland and oak woodland communities make up the vegetation habitats in the headwaters. A cascade falls was noted as a potential barrier to upstream migration in a CA Department of Fish and Game survey in 1992 (Titus et al., in draft). Sections of the creek are also known to run dry (Nelson, 2009b; Titus et al., in draft).

Various strains on the Santa Rosa Creek habitat have been observed over the past 50 years (Titus et al., in draft). Ninety percent of the watershed is privately owned (Duff 2007). Heavy water demands in this watershed exacerbate limited water supplies resulting in low stream flow and dry reaches creating unsuitable habitat for steelhead 
(Titus et al., in draft). The town of Cambria is situated on the lower watershed banks of Santa Rosa Creek and contributes pollution in the form of urban runoff and dumping (Titus et al., in draft). Cattle grazing and agricultural development contribute to sedimentation, loss of riparian habitat, and pollution. Several miles of denuded banks were observed including extensive areas lacking riparian vegetation over and around the creek channel (Nelson, 2009b). Nonnative invasive plant species were also documented in the 2005 survey (Nelson, 2009b). Additionally, steelhead/rainbow trout were stocked during several events during 1930's to the 1950's (Titus et al., in draft).

\section{Precipitation and Water Temperature}

Precipitation measurements from Cambria, California in the form of daily rainfall amounts were analyzed from microfiche records of the Telegraph Tribune Newspaper for the 1992-1993 rain season and from the Tribune Newspaper for the 2004-2005 rain season. The rain season, according to the newspapers, begins July 1 and runs through June 31 of the following year. Rain events were recorded as they occurred, noting the amount of precipitation in inches over a 24 hour period. Rain fall events were not documented over weekends, but added into the running total. Yearly rainfall totals for Cambria, CA were also recorded from the same sources for the 1991-1992, 1992-1993, 2003-2004, and the 2004-2005 seasons. Precipitation was graphically displayed to show rainfall amounts throughout the survey years and the year prior.

Stream temperature was recorded during stream flow surveys, daily out-migrant trapping, electrofishing sampling, and habitat surveys in 2005. HOBO® (Onset Computer Corporation, Bourne, MA) temperature data loggers were installed at specific 
locations on each watershed for the duration of the 2005 survey year to collect water temperature $\left(\mathrm{F}^{\circ}\right)$. Although temperature loggers were installed on San Simeon Creek in two locations, no data was recorded due to equipment malfunction. All temperature loggers on Santa Rosa Creek recorded data from June 2 to October 25, 2005 (Nelson, 2009b). The $\mathrm{HOBO} \circledast$ sites on Santa Rosa Creek were located at stream mile 0.6 (0.9 $\mathrm{km}), 8(12.9 \mathrm{~km})$, and $14.5(23.3 \mathrm{~km})$ in order to get a temperature profile for different locations throughout the watershed (Nelson, 2009b).

\section{Stream Flow}

Weekly stream flow was measured during both survey years. A Model 2000 Marsh-McBirney Flow-Mate (Hach Company, Loveland, CO) along with top-setting rod was used to calculate stream flow (Nelson, 1994, 1995; 2009a, b). Stream flow was measured at locations that met the parameters for adequate stream flow according to the protocol described in the Water Measurement Manual USBR (Bureau of Reclamation, 2001). Stream flow data was entered into Excel and graphs were created displaying the stream flow rate over the sampling period.

Stream flow surveys were conducted on San Simeon Creek in 1993 at stream mile $0.52(0.8 \mathrm{~km})$ and at $4.8(7.7 \mathrm{~km})$. Survey dates of the lower site included May 5 , $12,19,25,31$, June $7,17,24,30$, July 8 , and 19 . Stream flow was suspended at this location after July 19 due to reduced flow. Additional survey dates for the upper site were July 22, 29, Aug. 6, 24, Sept. 10, 15, 20, Oct. 1, 11, 25, and Nov 1, 1993. Stream flow was also recorded for Santa Rosa Creek at stream mile $2.0(3.2 \mathrm{~km})$ and 10.0 (16 km) in 1993. Survey dates on lower Santa Rosa Creek include May 5, 12, 19, 25, 27 
31 , June $7,17,24,30$, July $8,19,26,29$, August 24 , September 10, 15, and 20. The upper site was surveyed on the same dates and additionally on July 22, Aug. 6, Oct. 1, 11, 25, and Nov. 1, 1993 (Nelson, 1994, 1995).

In 2005, the location chosen for the San Simeon Creek stream flow site was located at stream mile $0.62(1 \mathrm{~km}), \mathrm{N} 35$ 35' $43.3 \mathrm{~W} 12107^{\prime} 00.6$ ". The 2005 stream flow site on Santa Rosa Creek was at stream mile 0.52 (0.8 km), N35 33' 57.6" W121 06' 05.8. Stream flow was surveyed once a week beginning on April 20, 2005 through August 30, 2005. Stream flow was determined for the additional dates of September 1, 8, 13, 20, October 5, 11, 17, and 24 on San Simeon Creek and on September 8, 13, 20, October 5, 17, and 24 on Santa Rosa Creek (Nelson, 2009 a, b).

\section{Habitat Surveys}

Stream habitat surveys were conducted on San Simeon and Santa Rosa Creeks in 1993 and 2005. All surveys followed the protocol described in the California Salmonid Stream Habitat Restoration Manual (Flosi et al., 1998). Stream habitat typing organizes stream characteristics into measurable units for which length, width, depth, and other variables are recorded. Individual stream 'units' were characterized by water flow behavior and depth and stream bed appearance resulting in 24 habitat types that are described in the aforementioned manual.

Habitat typing surveys conducted on San Simeon Creek began in June of 1993 at the confluence with Steiner Creek, stream mile $4.1(6.6 \mathrm{~km})$, and continued upstream to the anadromous limit or boulder falls located at stream mile $5.9(9.5 \mathrm{~km})$ (Nelson, 1995). San Simeon Creek was not surveyed below Steiner Creek in 1993 due to dry 
conditions downstream. This survey included the perennial reach of the stream. An anadromous limit for this study is characterized by a permanent, natural structure that migrating steelhead cannot pass, such as a high boulder jump or steep gradient bedrock sheet. San Simeon Creek was also habitat typed from August 15 through August 25, 2005, which began at the confluence with the Pacific Ocean and continued to the boulder falls (Nelson, 2009 a). Only 2005 data collected from the confluence of Steiner Creek to the boulder falls will be used for comparisons with 1993 data, where as the entire survey will be compared between creeks within the 2005 survey year.

In both survey years, Santa Rosa Creek habitat was assessed from the confluence with the Pacific Ocean and continued 14 miles $(22.5 \mathrm{~km})$ upstream (Nelson, 1994, 2009 b). The 1993 survey was conducted from July 13 to October 22 to stream mile $14.2(22.9 \mathrm{~km})$. Santa Rosa Creek was surveyed from September 7, 2005 to October 3, 2005 to stream mile $14.4(23.2 \mathrm{~km})$.

The data generated from these habitat surveys was entered into the Stream Habitat 2.0.16 database designed for the Pacific States Marine Commission in conjunction with the California Department of Fish and Game (Wilson, 2006). Bar graphs were generated using Microsoft Excel to show habitat types by frequency of occurrence.

\section{Out-migrant Trapping}

Steelhead trout can choose to migrate downstream to the ocean or lagoon during the late winter and spring flows. In order to gain insight into the demographics of these migrants and the timing of their migration downstream, out-migrant traps were set up on 
San Simeon and Santa Rosa Creeks in the spring of 1993 and 2005. They were operational until the seasonal close off of the lagoon to the ocean.

During the 1993 field season, the trap on San Simeon Creek was located at stream mile $0.3(0.5 \mathrm{~km})$ and was operational April 7 to May 19, 1993 (Nelson, 1995). The out-migrant trap on Santa Rosa Creek was located at stream mile $1.2(1.9 \mathrm{~km})$ from April 26 to June 5, 1993 (Nelson, 1994). The trap set up during the 1993 surveys consisted of a weir, fyke net, and a rectangular live car (Nelson, 1994, 1995). Refer to Nelson reports from 1994 and 1995 for the dimensions and protocol of the trap setup.

In 2005, traps were also set up on San Simeon and Santa Rosa Creeks. Initially, a similar trap set up to the 1993 surveys was installed on San Simeon Creek on March 14 to March 22, 2005 when flash flood flows during a storm rendered the trap unfunctional (Nelson, 2005a). Refer to figure 4 for a picture of the initial trap setup. On April 14, 2005, a second trap was installed on San Simeon Creek at stream mile 0.35 $(0.6 \mathrm{~km})$ and remained operational until June 8, 2005 (Nelson, 2005a). This time, the trap used was a seven hoop fyke net trap and weir (Figure 5). Refer to Nelson reports $2009 a$ and $b$ for the dimensions of the trap setup. The trap was functional Monday through Friday with one weir left open on the weekends to allow for fish passage (Nelson 2005a, b). A similar trap was set up on Santa Rosa Creek and was operational from April 18 to May 25, 2005 (Nelson 2005b). This trap was only functional on the weekdays, as previously described for San Simeon Creek. See figure 6 for a photograph on the Santa Rosa out-migrant trap and weir.

The protocol established by Nelson was followed to trap and collect out-migrating juveniles in 1993 and 2005. Total length and fork length were measured on each fish to 
the nearest millimeter using one of several measuring boards. During the 1993 outmigrant survey, individual fish weight was recorded by means of displacement. This was done by placing a fish in a premeasured beaker of water and subtracting the difference after the fish had been added. The final milliliters displaced were then converted to grams $(1 \mathrm{~mL}=1 \mathrm{~g})$. In 2005 , weight was measured to the nearest 0.01 gram with an Ohaus Scout Pro portable balance (400 gram capacity).

Scale samples were removed from individuals over $80 \mathrm{~mm}$ in total length from the area above the lateral line, just posterior to the dorsal fin on the left side of the fish. Scales were gently scraped off using a pocket knife and put into coin envelopes that were sealed and labeled. The scales were allowed to dry in the envelopes. At a later date, the samples were removed from the envelopes and cleaned with water using forceps. Scale samples from each individual were mounted between two glass slides that were taped together. These slides were then labeled with their corresponding data (i.e. length, weight, date sampled).

The presence of disease or parasites such as Black Spot Disease and Salmonicola spp. was identified and recorded for each fish as well as any other obvious marks or conditions. Trout appearance was recorded according to the color variation that this fish displayed. Fish with highly visible parr marks, regardless of size, were recorded as "parr". Fish observed with a silvery sheen and fading parr marks were labeled as "partial smolts". Individuals with no parr marks or speckling but with a silver appearance, elongated/thinner body form, and black tipped forked caudal fin were noted as "smolts". Larger fish that retained their rainbow trout appearance of olive and speckled coloration with a pink/red lateral line and no parr marks were referred to as 
rainbow trout. Adult steelhead, including post spawned kelts, were noted where applicable. Not all adult fish had weights recorded or scale samples taken. In addition to steelhead, other vertebrate species present in the trap live car were recorded.

\section{Electrofishing}

Electrofishing surveys were conducted on San Simeon and Santa Rosa Creeks in 1993 and 2005. During September of 1993, 10 survey sites of 100 feet in length were randomly selected from the 1.5 miles of surveyed stream on San Simeon Creek. The protocol for the electrofishing surveys conducted during September on Santa Rosa Creek followed that of previous studies conducted in this watershed (Nelson, 1994). Fifty two 100 foot long sections were selected from the surveyed length and four to six 100 foot stations were randomly selected to be surveyed within each stream mile (Nelson, 1994). At each survey site, block seine nets were installed at the upper and lower end of the 100 foot stretches to prevent fish movement in or out of the survey area. Beginning downstream and working upstream, fish were collected using a SmithRoot Model 12 backpack electrofishing unit with a frequency of $\mathrm{J} 4$ and 200 volts (Nelson, 1994, 1995). In order to efficiently sample a station, a minimum of three passes at each site was conducted according to a multiple pass removal method (Zippin, 1958).

The collected fish were measured according to total length and scale samples were taken from individuals over 100mm (Nelson, 1994, 1995). At each site on San Simeon Creek, the fish sampled were weighed collectively by the previously described method of displacement in order to get a measure of biomass for each location. 
Weighing by digital scale and displacement methods was used to acquire the biomass of steelhead sampled at each site on Santa Rosa Creek. The fish were subsequently released downstream of the lower block net to avoid recounting. Additional species caught were noted.

The site selection protocol for the electrofishing surveys conducted in 2005 varied from those in 1993. San Simeon and Santa Rosa Creeks were both sampled in October, 2005. On San Simeon Creek, sampling sites were based on how well the habitat represented the reach, choosing sites that included the most abundant habitat units observed in each reach (Nelson, 2009 a). Three 100 foot long sampling sites were selected and followed the same electrofishing protocol as previously mentioned for the 1993 survey year with the following additions/exception (Table 1). During each pass, collected fish were held in freestanding mesh live cars away from the electrical field until the top of the survey site was reached. Additionally, scale samples were not collected from surveyed fish. Santa Rosa Creek also varied in site selection. Ten sites

were chosen throughout the watershed according to their characteristics (Table 1). The length of each site ranged from 150 to 398 feet depending on the habitat units they included (Nelson, 2009 b). The actual electrofishing protocol was the same as San Simeon Creek in 2005. All information was recorded on waterproof datasheets.

\section{Data Analysis}

Demographic data such as total length, fork length, and weight was recorded from the sampled individuals on both creeks in during 2005. Weight data was collected by means of a portable balance as aforementioned in the out-migrant trap methods. In 
some instances, fork length was not recorded for several sample sites on Santa Rosa Creek.

The demographic data collected about the steelhead from San Simeon and Santa Rosa Creeks during both survey years was used to gain insight into these threatened populations. Microsoft Excel was used to generate frequency and percent frequency distribution histograms of fork and total lengths of fish caught in out-migrant traps and during electrofishing surveys. The Fulton Condition Factor $(\mathrm{K}=$ $\left.W / L^{3}(100,000)\right)$ is a measure of condition, plumpness, or well-being and was used to calculate a relationship between length and weight (Tesch 1968). Condition factors in fisheries work are based on the relationship: $W=\mathrm{CL}^{b}$, where $W=$ Weight, $L=$ Length, $c=$ constant and $b=$ slope of the regression of natural log transformed $L$ and $W$ data (Anderson and Gutreuter, 1983). Minitab® statistical software (version 16) was used to examine length weight relationships between steelhead sampled in out-migrant traps in 1993 and 2005 and those sampled by means of electrofishing in 2005. The natural logs of length and weight were graphed to show their linear relationship. Multiple regression analyses were conducted to compare fork length/weight relationships of steelhead electrofished from the two different watersheds.

\section{Age Determination and Scale Analysis}

Scale photography and reading were conducted from 2009 to 2011 on the samples collected during the out-migrant trapping of 1993 and 2005 on San Simeon and Santa Rosa Creeks. The collected scales had been previously cleaned with water using forceps and mounted between two glass slides that were taped together and 
labeled with their corresponding data (i.e. length, weight, date sampled). The slides were placed on the stage of a Nikon Optihot-2 phase contrast microscope using the $E$ Plan 4/0.1 160/- objective. A Nikon D-50 (3008 x 2000 pixels) single lens reflex (SLR) camera was mounted to the microscope using a Nikon f-mount. Photographs were taken of the scales using the ph1 phase with a shutter speed of $1 / 50$. The three best scale samples from each fish were photographed and saved as .jpg files.

Steelhead scales are cycloid in shape and contain centric ridges called circuli (Jearld, 1983). The bands of closely positioned circuli that form during periods of slow growth annually are called annuli (Jearld, 1983). Regenerated scales form in place of a missing scale and can be identified by a clear center lacking circuli (Jearld, 1983). It is important to not include regenerated scales in the aging analysis as they are most likely missing annuli needed to accurately record age.

Steelhead trout can be aged by analyzing the circuli and annuli on an individual scale. There are differences in the protocol used to read a scale including which axis to take the measurements from. References on aging $O$. m. irideus scale samples vary in their point of reading from the 90 degree mark all the way to the 45 degree mark (Figure 7). Other reference lines used include the 20 degree mark (Bond et al., 2008) and the 30 degree mark (Coggins, 1994). In hopes to identify differences in collecting data along different reference lines, age estimates, circuli counts, and measurements were made on the 90 degree line and at the 45 degree line. In some instances (specifically with samples from Santa Rosa Creek), age data was recorded, but measurements needed for backcalculations such as radius length and circuli counts were not.

Scale circuli counting and measuring were conducted using the Adobe 
Photoshop CS3 computer program. The scale images were adjusted to display the correct orientation for further analysis with the anterior end facing upwards. A digital mark was made at the focus of each scale to act as a standard starting point for repeated measurements. Measurements were made from the focus to the outer edge of each annulus and to the outer edge of the scale (scale radius) at the 90 degree and the right 45 degree angles using the Photoshop measurement tool (Figure 7). The measurement tool was adjusted to allow for accurate measurements according to pixel length by making comparisons to a photographed micrometer at the same magnification. As a result, the size scale of 1.36 pixels was equal to one micrometer. Aging analysis followed the protocol described in Fisheries Techniques, Age Determination (Jearld, 1983). Each scale was read three separate times by the same reader. Age was categorized as a $1+, 2+$ or $3+$ with $1+$ being those individuals that displayed one complete annulus and additional circuli beyond, 2+ showing two distinct annuli, and so on. Each annulus equals 1 year. Those scales with the same age reading on at least two out of three readings were used for this study. In order to accommodate the uniqueness of the sampled populations, trends in number of circuli to the first annuli and distinguishing annuli marks were taken into account when aging the scales. Scales that were regenerated past $4-5$ circuli were not included in aging and back calculations (Coggins 1994).

The age readings, circuli lengths, and radii lengths were entered manually into an Excel spreadsheet with the corresponding fish length, weight, and condition data. Once age was determined for each fish, graphical displays corresponding age with lengths and migration timing were conducted using Microsoft Excel. In order to obtain growth 
increments for the sampled steelhead at prior ages, backcalculations were conducted using the scale radius length, length to each annuli, and fork length measurements (Lagler, 1956). The direct-proportional formula used was $L^{\prime}=S^{\prime} / S(L)$ where $S^{\prime}=$ length of scale radius at annulus $x, S=$ total scale radius, $L=$ length of fish at time caught, and $L^{\prime}=$ length of fish at time annulus $x$ formed. Due to limited sampling sizes and young ages of the sampled fish, growth rates were not calculated. Total scale radius length $(\mu \mathrm{m})$ was plotted against fork length $(\mathrm{mm})$ for fish sampled from San Simeon and Santa Rosa Creeks in 2005. Results from both sample radii, $90^{\circ}$ and $45^{\circ}$, were included in these analyses. Multiple regression analysis was performed to discern differences between the fork length/ scale radius relationships from each creek. Circuli counts of age 1+ fish from each population and radius location were further analyzed by means of two-sample T-tests.

\section{RESULTS}

\section{Precipitation and Water Temperature}

Records of precipitation amounts on San Simeon and Santa Rosa creeks in 1993 were similar to those in 2005 (Figure 8). The total rainfall for Cambria, CA in the 19921993 season was 29.73 inches. The total in the $2004-2005$ season was 27.14 . Daily rainfall amounts for both seasons were also analyzed (Figures 9 and 10). The years prior to survey years were periods of drought followed by heavy rainfall events in the surveyed seasons. The total rainfall in the 1991-1992 season was 18.86 inches and 11.16 inches was the total rainfall amount recorded in the 2003-2004 season for Cambria, CA. The rainfall amount during the March 22, 2005 storm that negatively 
affected the initial out-migrant trap set up on San Simeon Creek was recorded in Cambria, CA as 1.27 inches in the Tribune on March 23, 2005.

Water temperature was recorded on Santa Rosa Creek from June 2 to Oct. 25, 2005. The three locations for the data loggers were selected to show variations in water temperature throughout the watershed. The lowest most site showed the greatest daily variation in temperature, reaching potentially lethal levels to steelhead trout $\left(>75^{\circ} \mathrm{F}\right.$, $24^{\circ} \mathrm{C}$ ) at various times (Figure 11). The middle site located at stream mile 8 showed higher variation from the mean during the first two months of data than the second half (Figure 11). The site highest in the watershed showed the least variability from the average daily temperature (Figure 11). The decrease in average temperatures observed in September and October can be attributed to less daylight and the lower angle of the sun during this time of the year.

\section{Stream Flow}

Stream flow during the 1992-1993 rain season was measured for San Simeon and Santa Rosa Creeks. Both creeks followed expected trends with flow rates decreasing with fewer rain events during the spring and summer months. During both survey years, stream flow fell below 5 CFS (cubic feet per second) beginning in June and continued to decrease through the summer and into the fall. Rainfall events during the spring of 1993 were observed with increased CFS on each creek (Figure 12). Higher stream flow rates on Santa Rosa Creek can be contributed to the larger watershed size resulting in greater volumes of water on this creek system. These trends were similarly observed for the stream flow rates for both of these creeks during 
the 2005 field season (Figure 13).

\section{Habitat Surveys}

Habitat mapping surveys were conducted during the 1993 and the 2005 survey years. In June of 1993, San Simeon Creek was surveyed from the confluence with Steiner Creek at stream mile 4.1. This location was selected because it was the start of flowing water and the beginning of the perennial reach. A total of 1.8 miles of stream habitat were surveyed until the boulder falls was reached at stream mile 5.9. A total of 128 units were observed, including 17 low gradient riffles, 11 cascades, 12 pocket water units, 6 glides, 12 runs, 25 step runs, 3 mid channel pools, 1 channel confluence pool, 11 step pools, 19 lateral scour backwater pools, 5 lateral scour root wad pools, 4 lateral scour bedrock pools, 1 lateral scour log pool, and 1 plunge pool. Of the units surveyed, step runs occurred the most frequently at $19.5 \%$ (Figure 14).

Santa Rosa Creek was surveyed in July of 1993 . There were fewer step habitat units observed on Santa Rosa then San Simeon Creek. A total of 1018 habitat units were identified within the 14.2 miles of stream surveyed beginning at the confluence with the Pacific Ocean. These observations included 198 low gradient riffles, 2 high gradient riffles, 9 units of pocket water, 98 glides, 249 runs, 48 stepruns, 7 mid channel pools, 2 channel confluence pools, 13 corner pools, 28 step pools, 45 lateral scour log pools, 161 lateral scour root wad pools, 43 lateral scour bedrock pools, 107 lateral scour boulder pools, 2 backwater root wad pools, and 6 plunge pools. Run habitat was the most commonly indentified unit at $24 \%$ (Figure 14).

Both creeks were surveyed again in 2005. Unlike 1993, the habitat mapping 
survey on San Simeon Creek began at the confluence with the Pacific Ocean and continued upstream to the boulder falls. There were a total of 222 units identified including 38 low gradient riffles, 51 glides, 24 runs, 25 step runs, 32 mid channel pools, 2 step pools, 17 lateral scour boulder pools, 20 lateral scour root wad pools, 12 bedrock scour pools, and 1 lateral scour log pool. Glide habitat was the most observed unit at $51 \%$ (Figure 15).

Santa Rosa Creek had a total of 857 stream habitat units recorded in 2005 . This survey included 128 low gradient riffles, 3 cascades, 59 glides, 254 runs, 16 step runs, 84 mid channel pools, 7 step pools, 11 corner pools, 58 lateral scour log pools, 80 lateral scour root wad pools, 74 lateral scour bedrock pools, and 83 later scour boulder pools. Similarly to 1993 , run habitat was the most frequently identified unit type at $30 \%$ (Figure 15).

More telling comparisons between habitat data are those that look at changes from one survey year to the other. San Simeon habitat data was compared between each survey year within the same stream miles (Figure 16). The main difference between these survey years is that there appears to be higher gradient habitat types (i.e. riffles, cascades) observed in 1993 than in 2005. A higher percent frequency of flatwater habitat (i.e. glides, runs) is noted for the 2005 survey year. Figure 17 shows the percent frequency of habitat unit types for both the 1993 and 2005 survey years on Santa Rosa Creek. There is very little variation in habitat types throughout these survey years suggesting little change over time or the ability to quickly return to a baseline state. 


\section{Out-migrant Trapping and Age Determination}

Out-migrant trapping was conducted on San Simeon and Santa Rosa Creeks during the spring seasons of 1993 and 2005. A total of 10 fish were caught in the outmigrant trap on San Simeon Creek in 1993. On Santa Rosa Creek, 22 fish were caught in the out-migrant trap, including 3 steelhead kelts (post-spawned adults). Refer to figure 18 and 19 for the length frequency and the percent frequency distributions of steelhead caught on San Simeon and Santa Rosa Creeks in 1993. The scale samples collected for the limited number of fish in 1993 did not have enough usable samples and therefore that data is not included at this time.

Out-migrant trapping surveys were also completed on San Simeon and Santa Rosa Creeks in 2005. The trap collected a total of 227 fish on San Simeon, including 2 fish that did not have recorded fork lengths and 11 without weight data. A total of 348 fish were collected on Santa Rosa Creek. One individual did not have a recorded fork length and 4 did not have weight data. The fish without a recorded fork length was a steelhead kelt with a total length of $526 \mathrm{~mm}$. This fish was not included the data analysis of juvenile fish caught in the trap.

The frequency distribution of fork lengths for steelhead caught from San Simeon creek in 2005 shows a strong bimodal pattern with a peak in the fork length of fish caught around the $70 \mathrm{~mm}$ range and a second peak around the $160 \mathrm{~mm}$ mark (Figure 20 and 21). The lengths of fish caught on Santa Rosa Creek that same year display a different pattern. The size classes most frequently observed in this watershed were in the 140 to $150 \mathrm{~mm}$ range (Figures 20 and 21). Steelhead sampled from both creeks similarly show that the average fork length of individuals generally decrease as the 
trapping season continues (Figure 22). Larger fish were sampled at the beginning of the trapping season and the majority of smaller fish were sampled towards the end.

Fish lengths and their corresponding weights have a curvilinear relationship. In order to see these trends in a linear fashion, the natural logarithm of fork length and weight data were computed. The length data for each survey year had a strong, positive correlation to the weight data. In 1993, the 10 steelhead on San Simeon Creek and 18 of the 22 steelhead caught on Santa Rosa Creek were graphed with regression lines included (Figures 23).

A total of 210 fish were used in this analysis for San Simeon Creek during the 2005 survey year. There are two clusters of data on the regression line possibly representing different age classes (Figure 24). The $\mathrm{R}^{2}$ value of the San Simeon Creek regression equation is 0.99 . As observed in the fork length distribution data, the length/weight relationship of fish caught on Santa Rosa Creek in 2005 show that the majority of the fish are represented in one cluster. Three hundred and forty one O. m. irideus juveniles are shown in Figure 25 with the $97 \%$ of the variation in weight being explained by the variation in fork length $\left(R^{2}=0.977\right)$.

A multiple regression analysis was used to test the difference between the length/weight relationships of steelhead caught in the out-migrant trap on San Simeon Creek ( $N=210)$ versus those sampled from Santa Rosa Creek $(\mathrm{N}=341)$. Using the natural $\log (\mathrm{In})$ of weight as the response variable and In fork length, sample site, and an interaction between the In fork length and sample site as the predictor variables, this analysis shows that there is no significant difference between the fork length/weight regression slopes from San Simeon and Santa Rosa Creeks $(p=0.495)\left(R^{2}=0.986\right)$. 
Therefore, we cannot conclude that there is a significant difference between the length/weight relationships of steelhead caught on San Simeon Creek and those from Santa Rosa Creek (Table 2).

Condition factor $(\mathrm{K})$ is a measure of fish 'health' by creating a statistical relationship between fish length and weight (Lagler, 1956). Smolting steelhead tend to have lower condition factors then parr (Wedemeyer et al., 1980) due to the body elongation without corresponding weight gain. A normal condition factor is around 1 . The condition factor values for steelhead from both creeks slightly increased later in the trapping season (Figure 26). This could be correlated with the fact that steelhead parr make up the majority of observations towards the later trapping dates. These fish did not display smolting characteristics and therefore have higher condition factors.

Fish caught on San Simeon and Santa Rosa Creeks were identified and labeled according to differences in appearance. The out-migrant trap on San Simeon Creek collected 108 parr, 62 partial smolts, and 44 smolts with complete length and weight data (Figure 27). Smolts appear to migrate downstream during the beginning of the survey season and decrease as the season goes on. Parr represent the smaller size classes $(50-100 \mathrm{~mm})$ and the majority of them were observed in the San Simeon outmigrant trap during the latter half of the survey period. Santa Rosa Creek produced 73 parr, 207 partial smolts, and 63 smolts that were migrating downstream (Figure 28). Parr, partial smolt, and smolts are represented throughout the survey period, although the number of parr appears to increase towards the end of the season.

Of the 227 fish sampled from the out-migrant trap on San Simeon Creek in 2005, 58 individuals had scale samples that could be used for aging (Table 3). On Santa 
Rosa Creek that same survey year, 82 individuals were aged since they possessed readable scales (Table 3). It is important to note that in 2005 , only $25.6 \%$ of fish sampled from San Simeon Creek and $23.6 \%$ of fish from Santa Rosa Creek could be aged. It is assumed that these subsamples are representative of the population for those size and age ranges.

The In fork length versus the In weight was plotted for the steelhead that were aged on both creeks. Age takes a closer look at the length/weight relationship of those sampled. The data from San Simeon Creek (Figure 29) shows the break in the clusters of data as being age related. On the other hand, the data from Santa Rosa Creek shows less of a distinctive break between age groups (Figure 30).

Figures 31 and 32 illustrate the age distribution of migrating steelhead on San Simeon and Santa Rosa Creeks. Both creeks show older fish appear to be migrating earlier in the survey period then younger fish.

Growth increments play an important role in understanding the demographics of steelhead populations. The growth increments of fish aged on San Simeon and Santa Rosa Creeks are noted in Table 4. There were a total of 45 steelhead used to obtain growth increments from San Simeon and 72 from Santa Rosa Creek (Table 4). At both 90 and 45 degree radii, the growth increment for fish from Santa Rosa Creek appears to be greater than those from San Simeon Creek. Two year old fish from both creeks have similar growth increments in their first year, but fish from Santa Rosa Creek have almost double the growth increment of San Simeon fish in their second year.

\section{Electrofishing}

Electrofishing surveys were conducted on San Simeon and Santa Rosa Creeks 
in 1993 and 2005. In efforts to compare and contrast differences and similarities, all sampled fish were looked at collectively for each survey year. Further analysis of $O . m$. irideus surveyed from specific habitat types and distance upstream will be left for additional research.

In 1993, a total of 205 steelhead were sampled throughout the San Simeon Creek watershed via electrofishing (Figures 33 and 34). On Santa Rosa Creek, 1,369 fish were sampled, but only 1,099 were used in this analysis due to different sampling techniques (Figures 33 and 34). Although there is a greater number of fish sampled from Santa Rosa Creek, one can observe through percent frequency that there are differences between the lengths observed on both creeks. Steelhead sampled from San Simeon Creek have a greater number of fish sampled in the 50 to $100 \mathrm{~mm}$ range where as steelhead from Santa Rosa Creek show a greater representation in the 80 to $110 \mathrm{~mm}$ range.

The demographic data of steelhead electrofished from San Simeon and Santa Rosa Creeks in 2005 is shown in Table 5. There were a total of 347 steelhead sampled from San Simeon Creek in 2005 (Figures 35 and 37). Three of these individuals did not have recorded weights. In the same survey year, 1,274 steelhead were electrofished from Santa Rosa Creek (Figures 36 and 38). Of those collected, 965 individuals did not have fork length data recorded including 10 steelhead with no recorded demographic data. Due to the large number of fish without fork length data on this creek in 2005, total length distribution for this survey year graphs were included in this report. The percent frequency of steelhead total lengths from San Simeon and Santa Rosa Creek follow similar patterns with a higher representation of steelhead in the 70 to $90 \mathrm{~mm}$ bins, 
and decreasing in frequency with increasing total length (Figure 36). The lack of observations of Santa Rosa steelhead fork lengths observed in the 50 to $80 \mathrm{~mm}$ bins of Figures 37 and 38 is due to fork lengths not being recorded. When total lengths are compared between survey years, smaller fish $(<80 \mathrm{~mm})$ are underrepresented on San Simeon Creek in 1993.

The In length and In weight relationships of steelhead electrofished from San Simeon and Santa Rosa Creeks in 2005 are illustrated in Figure 39. Both sets of data show strong positive correlations. A multiple regression analysis was conducted to determine if there was a significant difference between the fork length/weight relationship of steelhead electrofished from San Simeon $(N=344)$ and Santa Rosa $(\mathrm{N}=309)$ Creeks (Table 6). Weight $(\mathrm{In})$ was used as the response variable and In fork length (FL), location (L), and an interaction between In fork length and location were the predictor variables. The $p$-value corresponding to the interaction term was $<0.0001$ indicating a significant difference between the length/weight relationships of steelhead electrofished from the San Simeon Creek watershed and the length/weight relationship of steelhead from the Santa Rosa Creek watershed. The $\mathrm{R}^{2}$ value was 0.9908 indicating that the predictors account for $99 \%$ of the variation in weight.

\section{Scale Analysis}

An analysis of fork length versus scale radius for steelhead found in the outmigrant traps on San Simeon and Santa Rosa Creeks shows differences in radius length between the 90 and 45 reference lines. Scale samples from San Simeon Creek show strong, positive correlations between fork length and scale radius. Pearson 
correlation coefficients $(r)$ were established for the relationship between the fork lengths of steelhead from San Simeon Creek and scale radius at $90^{\circ}(r=0.899)$ and $45^{\circ}(r=$ 0.880). The same analysis was performed on the fork lengths from Santa Rosa Creek and the $90^{\circ}(r=0.785)$ and $45^{\circ}(r=0.769)$ radii. Scale radius and fork length sampled from Santa Rosa Creek have a moderate, positive correlation. Scale radius length from the 90 degree line had higher $R^{2}$ values (San Simeon: 0.807, Santa Rosa: 0.775 ) then the lengths measured along the 45 degree line (San Simeon: 0.616, Santa Rosa: 0.592) (Figures 40 and 41). Both watersheds show scale radius to be greater at the 90 degree angle.

Multiple regression analyses were performed to look at the relationship of fork length to scale radius for steelhead sampled from each creek and at each scale radius sample location (e.g. $90^{\circ}$ and $45^{\circ}$ ). Using fork length as the response and scale radius, location, degree $\left(90^{\circ}\right.$ and $\left.45^{\circ}\right)$, an interaction between scale radius and location, and an interaction between scale radius and degree as predictors, these analyses showed that adjusting for radius degree, the fork length/scale radius relationship is significantly different at the two locations $(p<0.0001)$, and adjusting for location, the fork length/scale radius relationship is significantly different at both radius degrees $(p<$ 0.002) (Table 7).

Average circuli counts reveal differences between the two populations of steelhead trout. The average number of circuli to the first annuli for the sample of age $1+$ steelhead scales is larger on Santa Rosa Creek (15.8 circuli) than on San Simeon Creek (12.7 circuli) (Table 8). In order to identify whether or not the average number of circuli to the first annuli were significantly different between San Simeon and Santa 
Rosa Creeks, two sample t-tests were conducted. These tests revealed that there is a significant difference between the average circuli counts to the first annulus from age $1+$ steelhead sampled from San Simeon Creek versus those from Santa Rosa Creek $\left(90^{\circ}\right.$ : $t$ $\left.=-7.05, \mathrm{df}=104, \mathrm{p}<0.0001 ; 45^{\circ}: \mathrm{t}=-5.66, \mathrm{df}=104, \mathrm{p}<0.0001\right)($ Tables 9 and 10$)$. Paired t-tests were conducted to see the difference between circuli data compared between sample sites $\left(90^{\circ}\right.$ or $\left.45^{\circ}\right)$ within each creek. There did not appear to be a significant difference between the scale reading sites on the $90^{\circ}$ radius versus the $45^{\circ}$ of age $1+$ fish to the first annuli (San Simeon: $t=-0.34, p=0.737$; Santa Rosa: $t=1.64$, $p=0.105)($ Tables 11 and 12).

The sample size for age $2+$ and $3+$ year old fish is low due to regenerated or unreadable scale samples; therefore, the circuli averages for these ages are not representative of their corresponding age classes. Age 2+ fish from both creeks have similar mean circuli counts to the first annuli (12.5 circuli), but the circuli to the second annuli is different, with Santa Rosa having an average of $32.5+/-3.32$ circuli to the second annulus versus an average of $23+/-1.04$ observed on San Simeon scales (Table 8). This suggests that age 1+ and 2+ fish from Santa Rosa Creek laid down more annuli during the year prior to sampling then those fish observed on San Simeon Creek.

Although these steelhead were sampled throughout the spring, the majority of the scales analyzed for age show significant growth since their last annuli. The number of circuli observed along the $90^{\circ}$ radius after the last annuli of age $1+$ steelhead from San Simeon Creek on average is $19.7(+/-0.51)$ and $14.5(+/-0.4)$ for those sampled from Santa Rosa Creek (Table 8). Age 2+ steelhead from Santa Rosa Creek had an 
average of $8.2(+/-1.78)$ circuli laid down after the last annuli whereas San Simeon Creek steelhead had an average of $17(+/-0.82)$ circuli since the last annuli (Table 8).

\section{DISCUSSION}

San Simeon and Santa Rosa Creeks are located within the same geographic location and are subject to similar environmental conditions, but their habitat and steelhead populations appear to have different characteristics. The trends observed in the steelhead population demographics are similar to those of other central California coastal creeks. Information in this thesis will aid in understanding the life history patterns of steelhead populations within this DPS.

Environmental conditions including precipitation and stream flow appear to be similar within the San Simeon and Santa Rosa Creek watersheds. Both creeks are subject to the same rain events, although actual rain amounts might vary between and within each watershed. Stream flow rates documented in 1993 and 2005 show similar trends: higher flows during the wet winter and springs and decreasing flows with less precipitation in the summer and early fall.

At first glance, the habitat that makes up San Simeon and Santa Rosa Creeks seem very similar with flat, wide, meandering channels with small substrate types in the lower reaches to more confined, narrower channels with large substrate observed with increasing elevation. The differences lie within the occurrence and types of habitat units recorded within each watershed. Since both watersheds are not identical, habitat units cannot be directly compared between the two, although some important inferences can be made. Generally, habitat units followed similar frequency of occurrence between 
both creeks, with a few exceptions. One exception was that Santa Rosa Creek had higher frequency of run habitat then San Simeon Creek. When each creek was examined between survey years, San Simeon appeared to differ greatly in the most frequently observed habitat units whereas in both survey years, Santa Rosa Creek followed similar trends of habitat units recorded. These differences between habitat types observed between years could be attributed to variation in stream flow during the survey period, being that this creek was surveyed in June of 1993 and in August of 2005. Another option could be increased sediment movement throughout the watershed, essentially burying large substrate and degrading steepness. Stream habitat mapping is a subjective science and perception of individual habitat units can vary from person to person, even from watershed to watershed. It is important to maintain stability in the data collection by maintaining the same observers throughout the entire survey which was done in both survey years.

Additional differences and similarities between San Simeon and Santa Rosa Creeks can be observed within the populations of out-migrants. Although the number of fish caught in out-migrant traps during the 1993 season was low, Santa Rosa Creek had a wide range of total lengths observed from $70 \mathrm{~m}$ to $300 \mathrm{~mm}$, whereas San Simeon Creek migrants were only within the $170 \mathrm{~mm}$ to $200 \mathrm{~mm}$ range. It is important to note that from 1986 to 1992, coastal California suffered from a 6 year drought period. This could explain the low sample numbers observed during the out-migrant trapping in 1993. The larger fork lengths of the fish sampled could also be explained by the drought, suggesting a longer freshwater existence until prime conditions sparked downstream migration. Another consideration for lack of downstream migrants was the 
period in which the out-migrant traps were operational. A flux of downstream migrants might have occurred prior to the initial trapping dates in April, 1993.

During the 2005 out-migrant trap survey, the frequency distribution of steelhead fork lengths show a greater representation of smaller fish $(60-90 \mathrm{~mm})$ migrating down San Simeon Creek, while Santa Rosa Creek showed the majority of steelhead were around $130 \mathrm{~mm}$ to $150 \mathrm{~mm}$. The steelhead sampled from both creeks appear to follow general trends observed of out-migrants such as longer lengths and older age at earlier migration times (Shapovalov and Taft, 1954). The length/weight relationships of San Simeon and Santa Rosa Creek steelhead were not significantly different, suggesting a similar pattern was observed on both creeks.

Even with $25 \%$ of the trapped steelhead having readable scales, there were a few notable differences between the age and growth of steelhead sampled from San Simeon and Santa Rosa Creeks. The peaks observed within the fork length distribution of steelhead from San Simeon Creek appear to be closely correlated with age. On average, steelhead from San Simeon Creek have larger mean fork lengths and weights than of those similarly aged from Santa Rosa Creek. Growth increments appear to be greater on Santa Rosa Creek then those sampled from San Simeon. The number of circuli laid down to each annuli follows a similar pattern, with Santa Rosa having the greater amount. Conversely, circuli counts since the last annulus was formed are greater from San Simeon Creek steelhead. Further examination of circuli counts to the first annulus show that there are significant differences between the two populations of steelhead. The relationship between fork length and scale radius also suggests that these populations are significantly different. These differences in scale growth suggest 
that there are unidentified factors that are affecting steelhead growth differently between San Simeon and Santa Rosa Creeks.

Steelhead electrofished from San Simeon and Santa Rosa Creeks showed variation in the frequency of total length distribution between 1993 and 2005. In 1993, there was a higher representation of smaller fish (total length $50-70 \mathrm{~mm}$ ) observed on Santa Rosa Creek then in 2005. A larger percentage of steelhead approximately 100$150 \mathrm{~mm}$ in total length were observed on Santa Rosa Creek during the 2005 survey then in 1993. These differences could be caused by variation in habitat unit types surveyed or the time of the year the sampling took place (September, 1993 versus October, 2005). As mentioned previously, the extensive drought that took place prior to the 1993 survey year may also have contributed to differences observed between survey years. Analysis of the relationships between fork length and weight from steelhead electrofished from San Simeon and Santa Rosa Creeks during the 2005 survey year appear to have significantly different patterns. This result is could be affected by type of habitat sampled. There are a number of unknown additional variables (e.g. water temperature, food availability) that might play a role in the differences observed between the fork length and weight relationships of electrofished steelhead from these two watersheds. Additional research to discern these variables is suggested, especially since the fork length/weight relationships of steelhead sampled from out-migrant traps shows an opposing view.

With the threat of global climate change, many studies have been conducted to understand the effects of water temperature, stream flow, and food availability on steelhead growth. Boughton et al. (2007) suggested that temperature does play a role 
in steelhead growth, although the rates of growth during periods of high temperatures and food availability were varied. On the other hand, Railsback and Rose (1999) found that growth rate was more affected by variables dealing with food consumption rather than with temperature. Growth rates were further analyzed by Sogard et al. (2009) suggesting that low growth rates observed could be contributed to periods of low flow and low food availability. It was also observed in this study that high summer temperatures did not affect the growth rates of age $0+$ fish. San Simeon and Santa Rosa Creeks had extremely low stream flow rates recorded during the summer and fall months. Daily maximum temperatures over $70^{\circ} \mathrm{F}\left(21^{\circ} \mathrm{C}\right)$ degrees were observed frequently in the lower watershed of Santa Rosa Creek. Although variation in growth increments cannot be directly correlated to the temperatures or flow rates observed on these creeks, there is strong evidence that steelhead in these watersheds are persisting despite suboptimal living conditions.

It is theorized that steelhead on San Simeon and Santa Rosa Creeks have better conditions for growth in the winter than the summer months, resulting in increased winter growth and decreased summer growth. These growth patterns have been observed in other steelhead populations along the central coast of California (Hayes et al., 2008, Sogard et al., 2009). Hayes (as cited in, 2008) also noted that these growth patterns have resulted in annuli being laid down in September, during the periods of slow growth. This study reveals that the majority of the fish aged had 8-20 circuli added after the last annuli was laid down. Although it cannot be directly supported by this research, this observation of recent circuli formation in these watersheds suggests winter growth is a strong possibility. 
Recent research with tagged steelhead in the Santa Ynez River has suggested that false annuli markings on steelhead scales have resulted due to habitat changes (e.g. movement from one part of the watershed to another) (Horwath et al., 2011). Anomalies observed in the circuli of scales from San Simeon and Santa Rosa Creeks suggest that this may also be occurring in these watersheds. Periods of faster and slower growth observed between annuli could be contributed to movement through a watershed, where these changes can be contributed to water temperature or flow change or increased/decreased food availability. In depth research tracking steelhead in these watersheds might lead to a better understanding of habitat use, especially throughout seasonal changes.

The length of juvenile steelhead migrating downstream to a lagoon or open ocean is important to understanding the life strategies of different steelhead populations. It has been suggested that size at ocean entry is an important factor to whether that fish survives an ocean existence to return to spawn (Hayes et al., 2008, Bond et al., 2008). A study of hatchery steelhead returning from the ocean to Scott Creek in Santa Cruz County, CA revealed that approximately $92 \%$ of those returning were over $150 \mathrm{~mm}$ at time of ocean entry (Bond et al., 2008). If steelhead smaller than $150 \mathrm{~mm}$ are less likely to return to their native streams, approximately $60 \%$ of those migrating from San Simeon and Santa Rosa Creeks are less likely to survive to return to these watersheds. Further investigations should be conducted in order to gain insight into the age and size of mature adults that return to San Simeon and Santa Rosa Creeks.

Bond et al. (2008) also noted the importance of lagoon habitat with the 
observation of increased growth rates for estuarine-reared juvenile steelhead. If the downstream migrants from San Simeon and Santa Rosa Creeks are utilizing estuarine habitat to continue their growth before ocean entry, problematic issues such as dry lagoons or poor water quality are causing detrimental impacts to these populations of steelhead. During the 1993 habitat surveys, the lower 4 miles of San Simeon Creek were essentially dry (Nelson, 1995). Lagoon surveys completed on San Simeon and Santa Rosa Creeks by Jennifer Nelson's crew in 2005 noted extremely limited water availability and poor water quality at times (Nelson, unpublished data). Although this data is limited, these observations strongly suggest the need for more research to gain insight into how these steelhead populations use lagoon habitat, identify factors that are limiting steelhead in this habitat, and what measures can be taken to improve and manage this habitat for steelhead and other lagoon species.

Recent studies on the status of steelhead in California paint a grim picture for the fate of this species over the next 50 to 100 years. Problematic issues facing current populations of steelhead are mostly anthropogenic in origin including increased water consumption, poor land use practices, and a myriad of other detrimental impacts (Moyle et al., 2008). It is speculated that global climate change by means of drought, rising sea levels, and increasing temperatures will only exacerbate the aforementioned issues facing steelhead in California (Moyle et al., 2008). In the mid nineties, there were approximately 500 adult steelhead returning to the largest steelhead streams in the South-Central California Coast Steelhead DPS down from historical runs of approximately 27,000 adults within these same watersheds (NMFS-SWR, 2007). Although current run sizes seem severely reduced from historical counts, there has 
been little local extirpation throughout this DPS (NMFS-SWR, 2007).

South-Central California Coast steelhead consist of fragile populations that warrant more research. Analyzing steelhead demographics is important to understanding the life history patterns of steelhead in this DPS. Surveys that look closely at steelhead habitat and environmental conditions identify potential limiting factors that inhibit these populations. Further research should be designed with these unique characteristics in mind in order to support efficient and successful management practices. These steelhead are also on the cusp of the geographical endangered delineation and continue to have habitat that is impacted by human activities. It is not only important to conduct research in this area to prevent local extirpation, but to work towards the preservation of the species throughout its native range. 


\section{TABLES}

Table 1. Locations of electrofishing sites on San Simeon and Santa Rosa Creeks, 2005.

\begin{tabular}{|c|c|c|c|}
\hline Creek & Site & $\mathbf{N}$ & w \\
\hline \multirow[t]{3}{*}{ San Simeon } & 1 & $\mathrm{~N} 35^{\circ} 36^{\prime} 49.3^{\prime \prime}$ & W121 $04^{\prime} 17.0^{\prime \prime}$ \\
\hline & 2 & N35 $37^{\prime} 03.3^{\prime \prime}$ & $\mathrm{W} 121^{\circ} 04^{\prime} 04.3^{\prime \prime}$ \\
\hline & 3 & no gps & \\
\hline \multirow[t]{10}{*}{ Santa Rosa } & 1 & N35 $34^{\prime} 05.2^{\prime \prime}$ & W121 $01^{\circ} 13.8^{\prime \prime}$ \\
\hline & 2 & $\mathrm{~N} 35^{\circ} 34^{\prime} 00.2^{\prime \prime}$ & W121 $01^{\circ} 04.0^{\prime \prime}$ \\
\hline & 3 & N35 $33^{\prime} 49.9^{\prime \prime}$ & $\mathrm{W} 121^{\circ} 04^{\prime} 51.2^{\prime \prime}$ \\
\hline & 4 & N35 $33^{\prime} 59.2^{\prime \prime}$ & W121 $01^{\circ} 11.8^{\prime \prime}$ \\
\hline & 5 & N35 $34^{\prime} 09.9^{\prime \prime}$ & W121 $01^{\circ} 10.9^{\prime \prime}$ \\
\hline & 6 & N35 $34^{\prime} 18.3^{\prime \prime}$ & W120 $02^{\prime} 32.5^{\prime \prime}$ \\
\hline & 7 & $\mathrm{~N} 35^{\circ} 34^{\prime} 43.9^{\prime \prime}$ & W121 $1^{\circ} 00^{\prime} 00.1^{\prime \prime}$ \\
\hline & 8 & N35 $34^{\prime} 17.3^{\prime \prime}$ & W120 58' 45.7" \\
\hline & 9 & N35 $33^{\circ} 39.9^{\prime \prime}$ & W120 57' 26.9" \\
\hline & 10 & N35 $33^{\circ} 44.7^{\prime \prime}$ & W120 $56^{\prime} 42.6^{\prime \prime}$ \\
\hline
\end{tabular}

Table 2. Multiple regression analysis for fork length/weight relationship of steelhead caught in outmigrant traps on San Simeon $(N=210)$ and Santa Rosa $(N=341)$ Creeks in 2005. $y=-10.4939+$ 2.7899 FL + 0.0633 L $-0.0103 F L * L, R^{2}=0.9861$.

\begin{tabular}{|c|c|c|c|}
\hline Term & Coef. & SE Coef. & P \\
\hline Constant & -10.49 & 0.07 & 0.000 \\
(In) FL & 2.78 & 0.02 & 0.000 \\
Location & 0.06 & 0.07 & 0.387 \\
FL * Location & -0.01 & 0.02 & $\mathbf{0 . 4 9 5}$ \\
\hline
\end{tabular}


Table 3. Demographic data of steelhead caught in out-migrant traps on San Simeon and Santa Rosa Creeks, 2005.

\begin{tabular}{|c|c|c|c|c|c|c|c|c|}
\hline \multirow[b]{2}{*}{ Creek } & \multirow[b]{2}{*}{ Age } & \multirow[b]{2}{*}{ \# of Fish } & \multicolumn{2}{|c|}{ Fork Length } & \multicolumn{2}{|c|}{ Weight } & \multicolumn{2}{|c|}{ Condition Factor } \\
\hline & & & $\begin{array}{c}\bar{X} \\
(\mathbf{m m})\end{array}$ & SE & $\begin{array}{c}\bar{X} \\
(g)\end{array}$ & SE & $\begin{array}{c}\bar{X} \\
(\mathrm{~K})\end{array}$ & SE \\
\hline \multirow[t]{4}{*}{ San Simeon } & $0+$ & 13 & 95.23 & 2.49 & 10.03 & 0.676 & 0.99 & 0.0339 \\
\hline & $1+$ & 40 & 157.25 & 3.23 & 39.89 & 2.07 & 0.79 & 0.0194 \\
\hline & $2+$ & 4 & 182.25 & 1.11 & 54.5 & 3.89 & 0.76 & 0.0424 \\
\hline & $3+$ & 1 & 280 & & 211.5 & & 0.83 & \\
\hline Total & & 58 & & & & & & \\
\hline \multirow[t]{2}{*}{ Santa Rosa } & $1+$ & 76 & 141.16 & 2.26 & 29.3 & 1.38 & 0.82 & 0.0106 \\
\hline & $2+$ & 6 & 170.5 & 7.47 & 48.5 & 7.12 & 0.79 & 0.019 \\
\hline Total & & 82 & & & & & & \\
\hline
\end{tabular}

Table 4. Growth increments of aged steelhead caught in out-migrant traps on San Simeon and Santa Rosa Creeks, 2005.

\begin{tabular}{|c|c|c|c|c|c|c|c|}
\hline \multirow[b]{2}{*}{ Creek } & \multirow[b]{2}{*}{$\mathbf{N}$} & \multirow[b]{2}{*}{ Age } & \multirow[b]{2}{*}{$\begin{array}{l}\text { Year of } \\
\text { Growth }\end{array}$} & \multicolumn{2}{|c|}{ Growth Per Year $\left(90^{\circ}\right)$} & \multicolumn{2}{|c|}{ Growth Per Year $\left(45^{\circ}\right)$} \\
\hline & & & & $\begin{array}{c}\bar{X} \\
(\mathrm{~mm} / \mathrm{d})\end{array}$ & SE & $\begin{array}{c}\bar{X} \\
(\mathrm{~mm} / \mathrm{d})\end{array}$ & SE \\
\hline San Simeon & 40 & $1+$ & 1 & 0.1598 & 0.0041 & 0.1648 & 0.0040 \\
\hline & 4 & $2+$ & $\begin{array}{l}1 \\
2\end{array}$ & $\begin{array}{l}0.1495 \\
0.0988\end{array}$ & $\begin{array}{l}0.0078 \\
0.0033\end{array}$ & $\begin{array}{l}0.1622 \\
0.0931\end{array}$ & $\begin{array}{l}0.0101 \\
0.0931\end{array}$ \\
\hline & 1 & $3+$ & $\begin{array}{l}1 \\
2 \\
3 \\
\end{array}$ & $\begin{array}{l}0.1838 \\
0.1785 \\
0.2813\end{array}$ & & $\begin{array}{l}0.1862 \\
0.1613 \\
0.2946\end{array}$ & \\
\hline Total & 45 & & & & & & \\
\hline \multirow[t]{2}{*}{ Santa Rosa } & 66 & $1+$ & 1 & 0.1992 & 0.0035 & 0.2063 & 0.0039 \\
\hline & 6 & $2+$ & $\begin{array}{l}1 \\
2\end{array}$ & $\begin{array}{l}0.1450 \\
0.2004\end{array}$ & $\begin{array}{l}0.0110 \\
0.0388 \\
\end{array}$ & $\begin{array}{l}0.1495 \\
0.2051\end{array}$ & $\begin{array}{l}0.0127 \\
0.0390 \\
\end{array}$ \\
\hline Total & 72 & & & & & & \\
\hline
\end{tabular}


Table 5. Demographic data of steelhead caught by means of electrofishing on San Simeon and Santa Rosa Creeks, 2005. Data does not include individuals with missing demographic data.

\begin{tabular}{|c|c|c|c|c|c|c|c|c|c|c|}
\hline \multirow[b]{2}{*}{ Creek } & \multirow[b]{2}{*}{ Site } & \multirow[b]{2}{*}{$\begin{array}{l}\text { \# of } \\
\text { Fish }\end{array}$} & \multicolumn{2}{|c|}{ Fork Length } & \multicolumn{2}{|c|}{ Total Length } & \multicolumn{2}{|c|}{ Weight } & \multicolumn{2}{|c|}{ Condition Factor } \\
\hline & & & $\underset{(\mathrm{mm})}{\overline{\mathbf{X}}}$ & SE & $\underset{(\mathbf{m m})}{\overline{\mathbf{X}}}$ & SE & $\begin{array}{c}\bar{X} \\
(\mathrm{~g})\end{array}$ & SE & $\underset{(\mathrm{X})}{\bar{X}}$ & SE \\
\hline \multirow[t]{3}{*}{ San Simeon } & 1 & 42 & 108.5 & 2.84 & 116.0 & 3.02 & 16.9 & 1.37 & 1.0 & 0.0175 \\
\hline & 2 & 89 & 99.5 & 2.03 & 106.6 & 2.19 & 12.7 & 0.83 & 1.0 & 0.0070 \\
\hline & 3 & 213 & 96.4 & 2.83 & 102.4 & 2.97 & 16.2 & 1.99 & 1.0 & 0.0068 \\
\hline Total & & 344 & & & & & & & & \\
\hline \multirow[t]{10}{*}{ Santa Rosa } & 1 & 3 & 205.7 & 4.18 & 220.0 & 3.51 & $\begin{array}{c}106 . \\
2 \\
\end{array}$ & 7.58 & 1.0 & 0.0282 \\
\hline & 2 & 12 & 177.0 & $\begin{array}{c}10.3 \\
0 \\
\end{array}$ & 188.4 & 10.50 & 81.2 & $\begin{array}{c}14.9 \\
0 \\
\end{array}$ & 1.1 & 0.0276 \\
\hline & 3 & 27 & 175.7 & 7.73 & 187.2 & 7.98 & 76.7 & 9.24 & 0.9 & 0.0486 \\
\hline & 4 & 50 & 155.2 & 3.70 & 165.8 & 3.86 & 55.2 & 4.46 & 1.1 & 0.0167 \\
\hline & 5 & 154 & NA & & 168.1 & 2.69 & 52.5 & 2.70 & 1.0 & 0.0067 \\
\hline & 6 & 43 & 132.2 & 4.03 & 141.4 & 4.21 & 30.3 & 3.15 & 0.9 & 0.0126 \\
\hline & 7 & 174 & 108.8 & 1.81 & 116.3 & 1.96 & 17.1 & 0.92 & 1.0 & 0.0619 \\
\hline & 8 & 339 & NA & & 101.7 & 1.45 & 12.1 & 0.67 & 0.9 & 0.0043 \\
\hline & 9 & 234 & NA & & 98.8 & 2.05 & 11.8 & 0.99 & 0.9 & 0.0055 \\
\hline & 10 & 228 & $N A$ & & 92.4 & 1.96 & 9.6 & 0.84 & 0.9 & 0.0076 \\
\hline Total & & 1264 & & & & & & & & \\
\hline
\end{tabular}

Table 6. Multiple regression analysis for the fork length/weight relationship of steelhead caught by means of electrofishing on San Simeon $(\mathrm{N}=344)$ and Santa Rosa $(\mathrm{N}=309)$ Creeks in 2005. $y=-11.28+2.98$ $F L-0.39 L+0.09 F L * L, R^{2}=0.9908$.

\begin{tabular}{|c|c|c|c|}
\hline Term & Coef. & SE Coef. & $\mathbf{P}$ \\
\hline Constant & -11.28 & 0.06 & 0.000 \\
(In) FL & 2.98 & 0.01 & 0.000 \\
Location & -0.39 & 0.06 & 0.000 \\
FL $^{*}$ Location & 0.09 & 0.01 & $\mathbf{0 . 0 0 0}$ \\
\hline
\end{tabular}


Table 7. Multiple regression analysis for fork length versus scale radius $\left(90^{\circ}\right.$ and $\left.45^{\circ}\right)$ from steelhead caught in out-migrant traps on San Simeon $(N=50)$ and Santa Rosa $(N=72)$ Creeks in 2005. $y=42.9922-3.0333 D+15.2873 L+0.1525 S R-0.0209 S R{ }^{*} L+0.0194 S R{ }^{*} D, R^{2}=0.7212$.

\begin{tabular}{|c|c|c|c|}
\hline Term & Coef. & $\begin{array}{c}\text { SE } \\
\text { Coef. }\end{array}$ & P \\
\hline Constant & 42.9922 & 4.42579 & 0.000 \\
Degree (D) & -3.0333 & 4.37027 & 0.488 \\
Location (L) & 15.2873 & 3.94964 & 0.000 \\
Scale Radius (SR) & 0.1525 & 0.00636 & 0.000 \\
SR ${ }^{*}$ L & -0.0209 & 0.00554 & $\mathbf{0 . 0 0 0}$ \\
SR ${ }^{*}$ D & 0.0194 & 0.00631 & $\mathbf{0 . 0 0 2}$ \\
\hline
\end{tabular}


Table 8. Circuli counts for age 1+, 2+, and 3+ steelhead from San Simeon Creek ( $N=45)$ and for age 1+ and 2+ steelhead on Santa Rosa Creek $(\mathrm{N}=72)$. All fish were caught in the out-migrant traps in 2005 .

\begin{tabular}{|c|c|c|c|c|c|c|c|c|c|c|c|c|c|}
\hline \multirow[b]{3}{*}{ Creek } & \multirow[b]{3}{*}{$\mathbf{N}$} & \multirow[b]{3}{*}{ Age } & \multirow{3}{*}{$\begin{array}{l}\text { Year of } \\
\text { Growth }\end{array}$} & \multicolumn{5}{|c|}{$90^{\circ}$ Radius } & \multicolumn{5}{|c|}{$45^{\circ}$ Radius } \\
\hline & & & & \multicolumn{3}{|c|}{ Circuli to Annuli } & \multicolumn{2}{|c|}{$\begin{array}{c}\text { Circuli from Last } \\
\text { Annuli to Scale Edge }\end{array}$} & \multicolumn{3}{|c|}{ Circuli to Annuli } & \multicolumn{2}{|c|}{$\begin{array}{c}\text { Circuli from Last } \\
\text { Annuli to Scale Edge }\end{array}$} \\
\hline & & & & $\bar{x}$ & SE & Range & $\bar{x}$ & SE & $\bar{x}$ & SE & Range & $\bar{x}$ & SE \\
\hline \multirow{3}{*}{ San Simeon } & 40 & $1+$ & $1 \mathrm{st}$ & 12.70 & 0.23 & 8 to 15 & 19.70 & 0.51 & 12.78 & 0.29 & 8 to 15 & 20.00 & 0.49 \\
\hline & 4 & $2+$ & $\begin{array}{l}\text { 1st } \\
\text { 2nd }\end{array}$ & $\begin{array}{l}12.50 \\
23.00\end{array}$ & $\begin{array}{l}0.65 \\
1.04\end{array}$ & $\begin{array}{l}11 \text { to } 14 \\
10 \text { to } 12\end{array}$ & 17.00 & 0.82 & $\begin{array}{l}13.25 \\
22.75\end{array}$ & $\begin{array}{l}0.48 \\
1.31\end{array}$ & $\begin{array}{l}12 \text { to } 14 \\
8 \text { to } 11\end{array}$ & 16.50 & 1.44 \\
\hline & 1 & $3+$ & $\begin{array}{l}\text { 1st } \\
\text { 2nd } \\
\text { 3rd }\end{array}$ & $\begin{array}{l}14.00 \\
14.00 \\
16.00\end{array}$ & & $\begin{array}{l}14.00 \\
14.00 \\
16.00\end{array}$ & 10.00 & & $\begin{array}{l}11.00 \\
10.00 \\
17.00\end{array}$ & & $\begin{array}{l}11.00 \\
10.00 \\
17.00\end{array}$ & 9.00 & \\
\hline Total & 45 & & & & & & & & & & & & \\
\hline \multirow[t]{2}{*}{ Santa Rosa } & 66 & $1+$ & $1 \mathrm{st}$ & 15.77 & 0.31 & 11 to 23 & 14.50 & 0.40 & 15.42 & 0.32 & 11 to 20 & 14.20 & 0.39 \\
\hline & 6 & $2+$ & $\begin{array}{l}\text { 1st } \\
\text { 2nd }\end{array}$ & $\begin{array}{l}12.50 \\
32.50 \\
\end{array}$ & $\begin{array}{l}1.20 \\
3.32 \\
\end{array}$ & $\begin{array}{c}8 \text { to } 17 \\
12 \text { to } 32 \\
\end{array}$ & 8.20 & 1.78 & $\begin{array}{l}11.50 \\
30.33 \\
\end{array}$ & $\begin{array}{l}0.99 \\
2.94 \\
\end{array}$ & $\begin{array}{c}7 \text { to } 14 \\
12 \text { to } 32\end{array}$ & 8.00 & 1.67 \\
\hline Total & 72 & & & & & & & & & & & & \\
\hline
\end{tabular}


Table 9. Two sample t-test comparing the mean number of circuli to the first annuli of age $1+$ steelhead scales sampled along the $90^{\circ}$ radius line from San Simeon and Santa Rosa Creeks.

\begin{tabular}{|l|c|c|c|}
\hline Creek & N & Mean & SE \\
\hline San Simeon & 40 & 12.7 & 0.227 \\
Santa Rosa & 66 & 15.8 & 0.310 \\
\cline { 2 - 3 } & T= -7.05 & $\mathbf{P}<\mathbf{0 . 0 0 0 1}$ \\
\cline { 2 - 4 }
\end{tabular}

Table 10. Two sample t-test comparing the mean number of circuli to the first annuli of age $1+$ steelhead scales sampled along the $45^{\circ}$ radius line from San Simeon and Santa Rosa Creeks.

\begin{tabular}{|l|c|c|c|}
\hline Creek & N & Mean & SE \\
\hline San Simeon & 40 & 12.8 & 0.285 \\
Santa Rosa & 66 & 15.4 & 0.320 \\
\hline
\end{tabular}

\begin{tabular}{|l|l|}
\hline$T=-5.66$ & $P<0.0001$ \\
\hline
\end{tabular}

Table 11. Paired t-test comparing the mean number of circuli to the first annuli of age $1+$ steelhead scales sampled along the $45^{\circ}$ and $90^{\circ}$ radius lines from San Simeon Creek.

\begin{tabular}{|l|c|c|c|c|}
\hline Creek & Radius & N & Mean & SE \\
\hline San Simeon & 90 & 40 & 12.700 & 0.227 \\
& 45 & 40 & 12.775 & 0.285 \\
\hline
\end{tabular}

\begin{tabular}{|l|l|}
\hline$T=-0.34$ & $P=0.737$ \\
\hline
\end{tabular}

Table 12. Paired t-test comparing the mean number of circuli to the first annuli of age $1+$ steelhead scales sampled along the $45^{\circ}$ and $90^{\circ}$ radius lines from Santa Rosa Creek.

\begin{tabular}{|l|c|c|c|c|}
\hline Creek & Radius & N & Mean & SE \\
\hline Santa Rosa & 90 & 66 & 15.773 & 0.310 \\
& 45 & 66 & 15.424 & 0.320 \\
\hline
\end{tabular}

\begin{tabular}{|l|l|}
\hline$T=1.64$ & $P=0.105$ \\
\hline
\end{tabular}




\section{FIGURES}

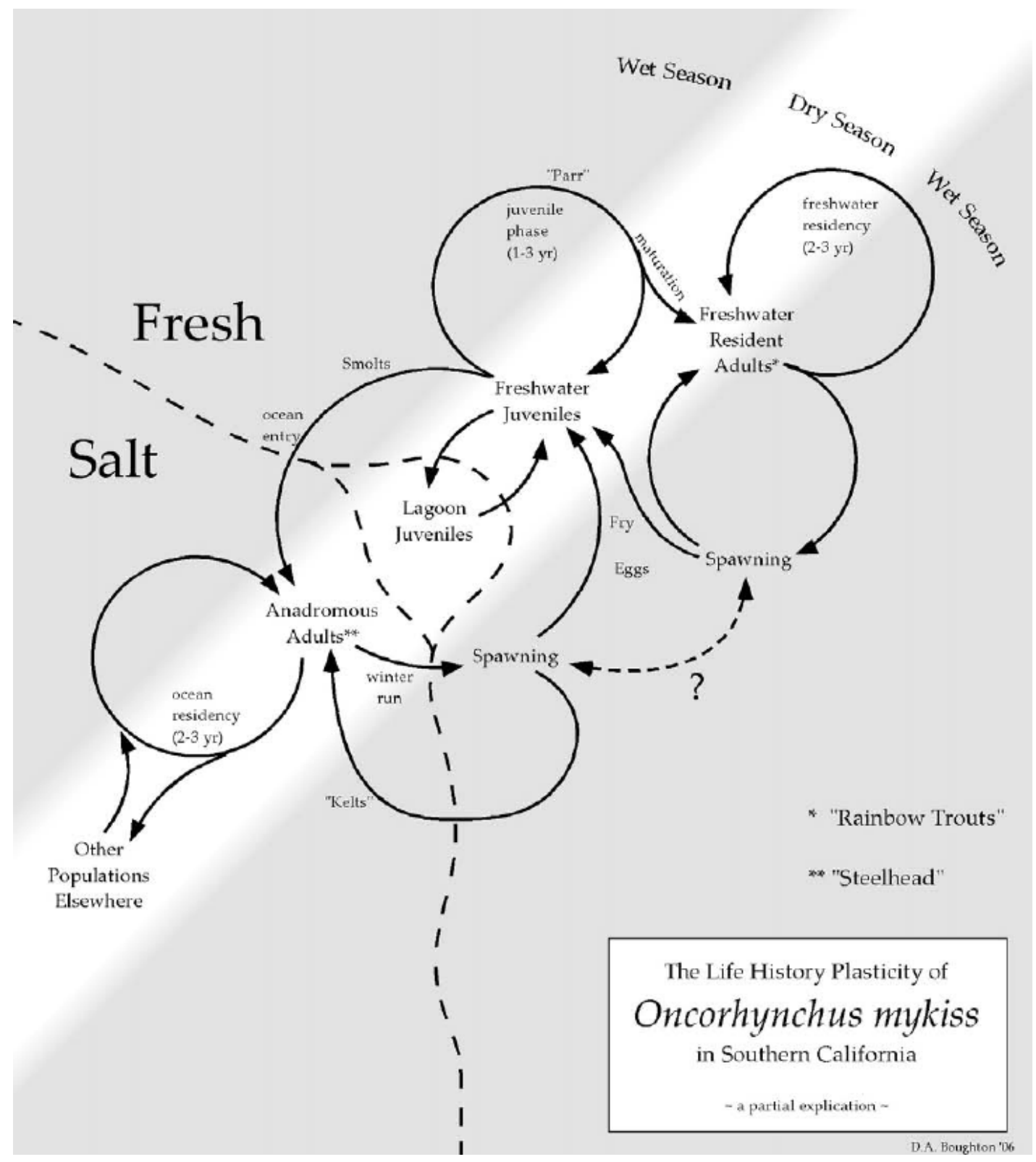

Figure 1. Steelhead trout development options. (Boughton et al., 2006). 


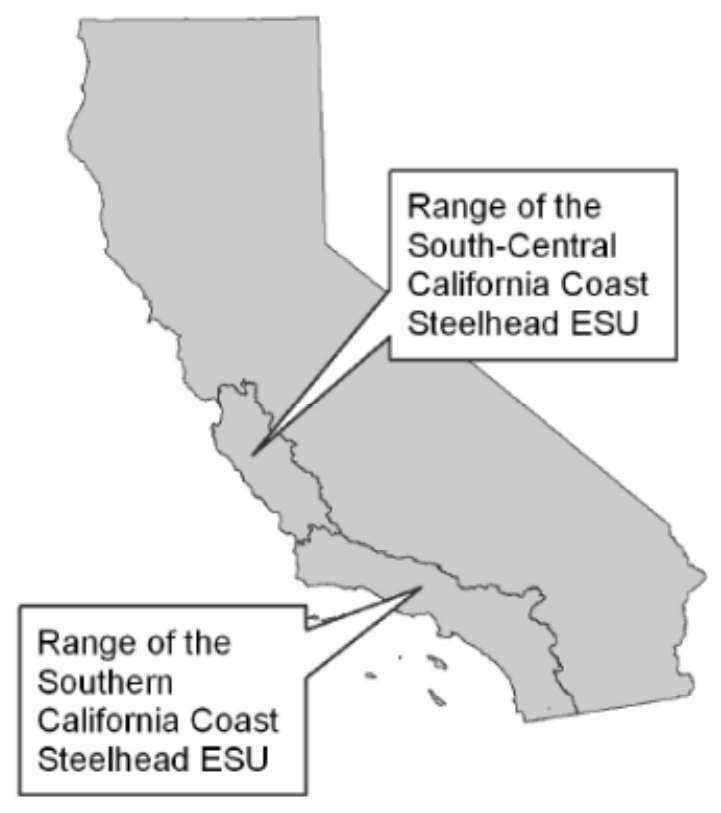

Figure 2. South-Central and Southern California Coast Steelhead ESUs. (Boughton et al., 2006). 


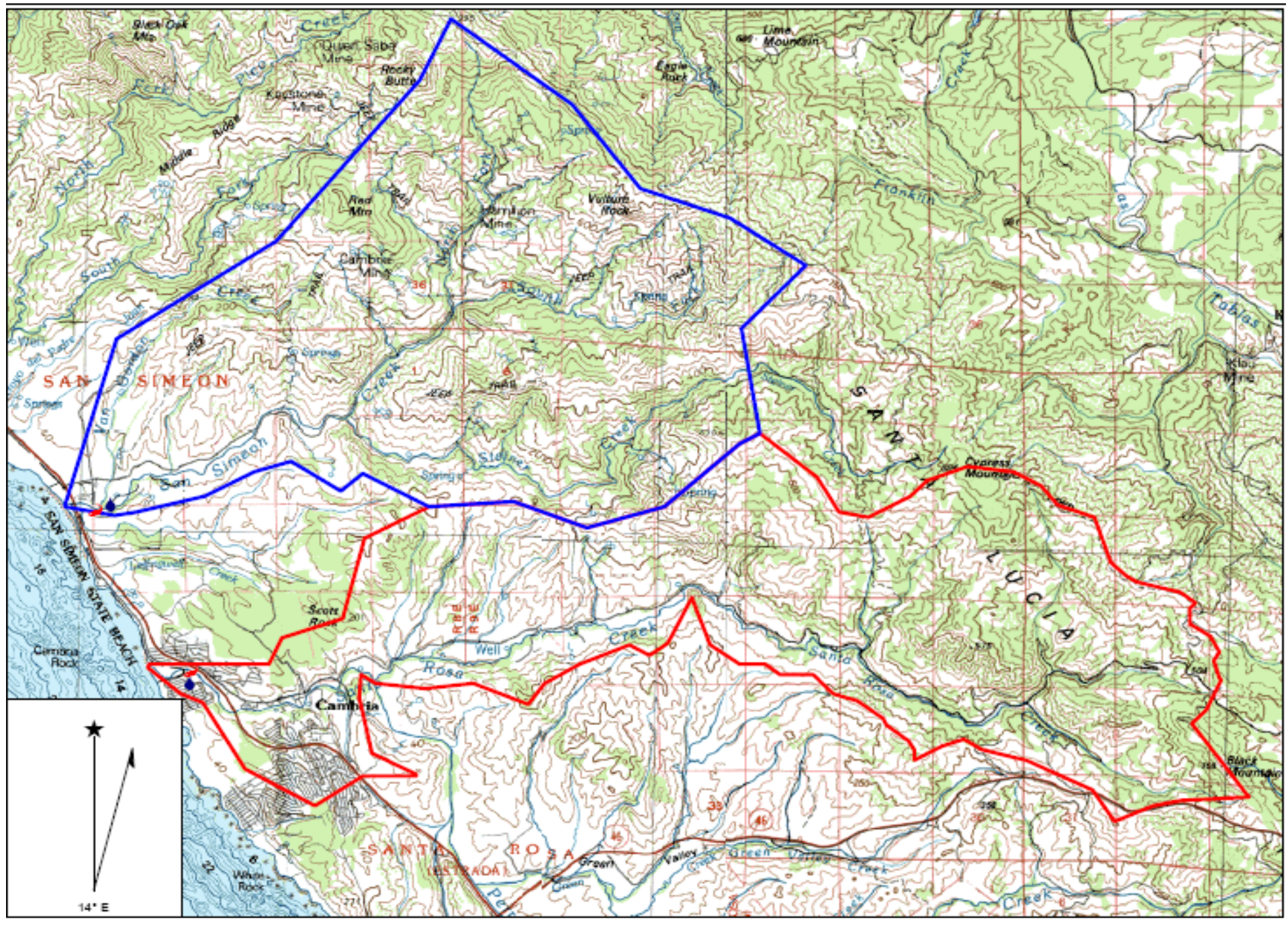

Figure 3. Watershed delineations, stream flow site locations, and trap locations for San Simeon and Santa Rosa Creeks, 2005. Water drop icon refers to proposed stream flow site location on each creek. Red fish icon refers to a proposed out-migrant trap location on each creek. The solid blue line outlines the San Simeon Creek watershed. The solid red line outlines the Santa Rosa Creek watershed, not including Perry Creek. 


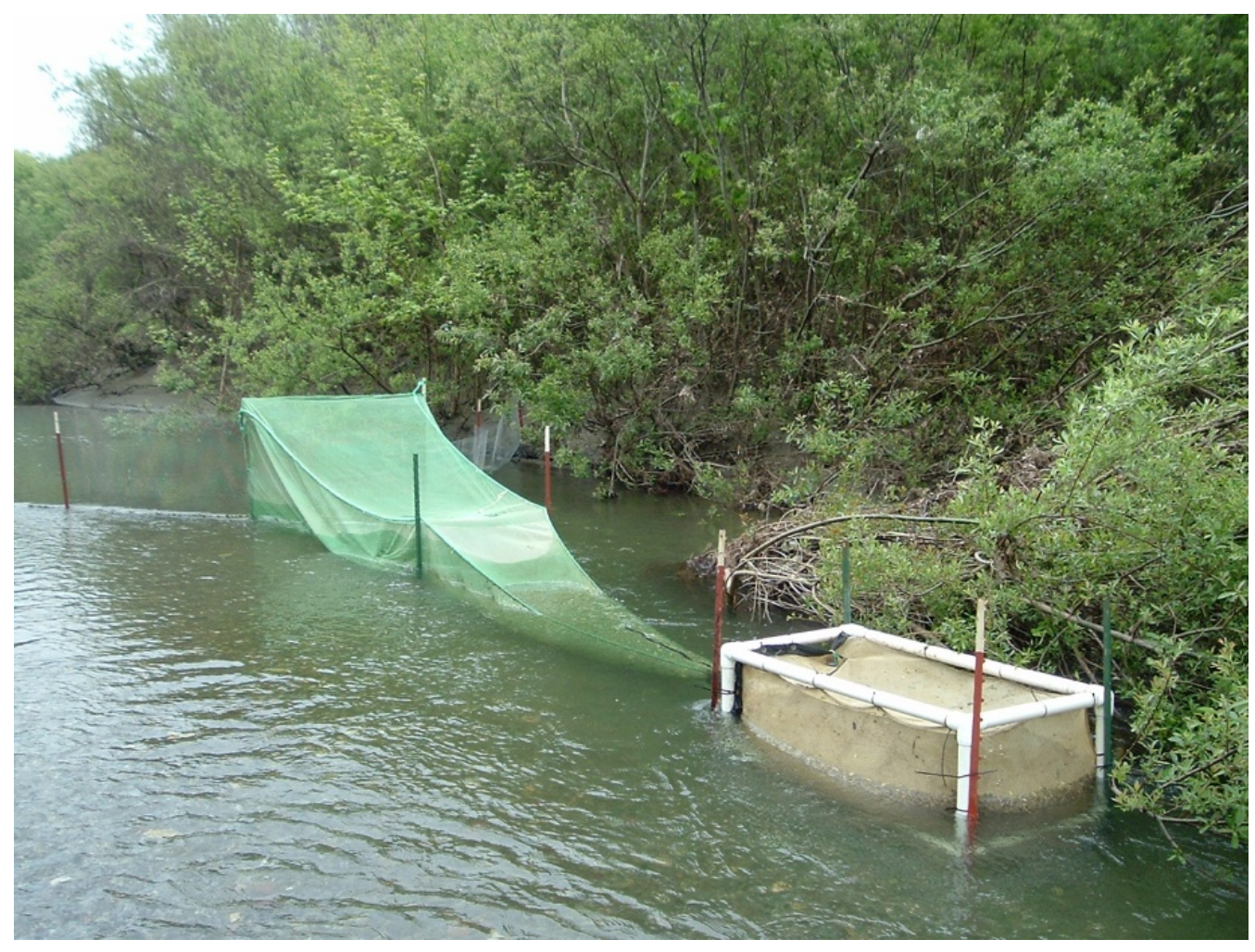

Figure 4. Out-migrant fyke net and weir setup on San Simeon Creek from March 14 to March 22, 2005.

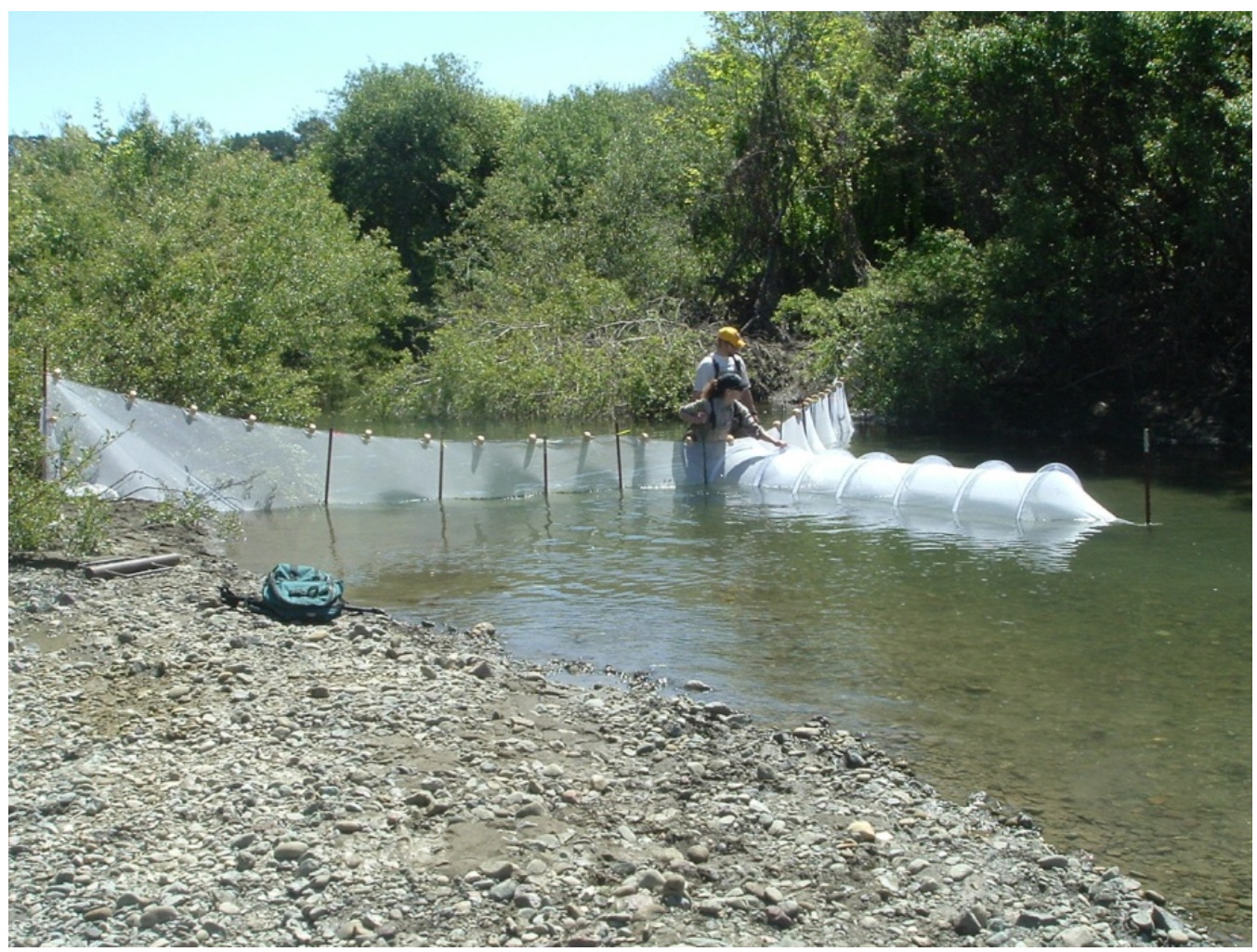

Figure 5. Out-migrant fyke net and weir setup on San Simeon Creek from April 14 to June 8, 2005. 


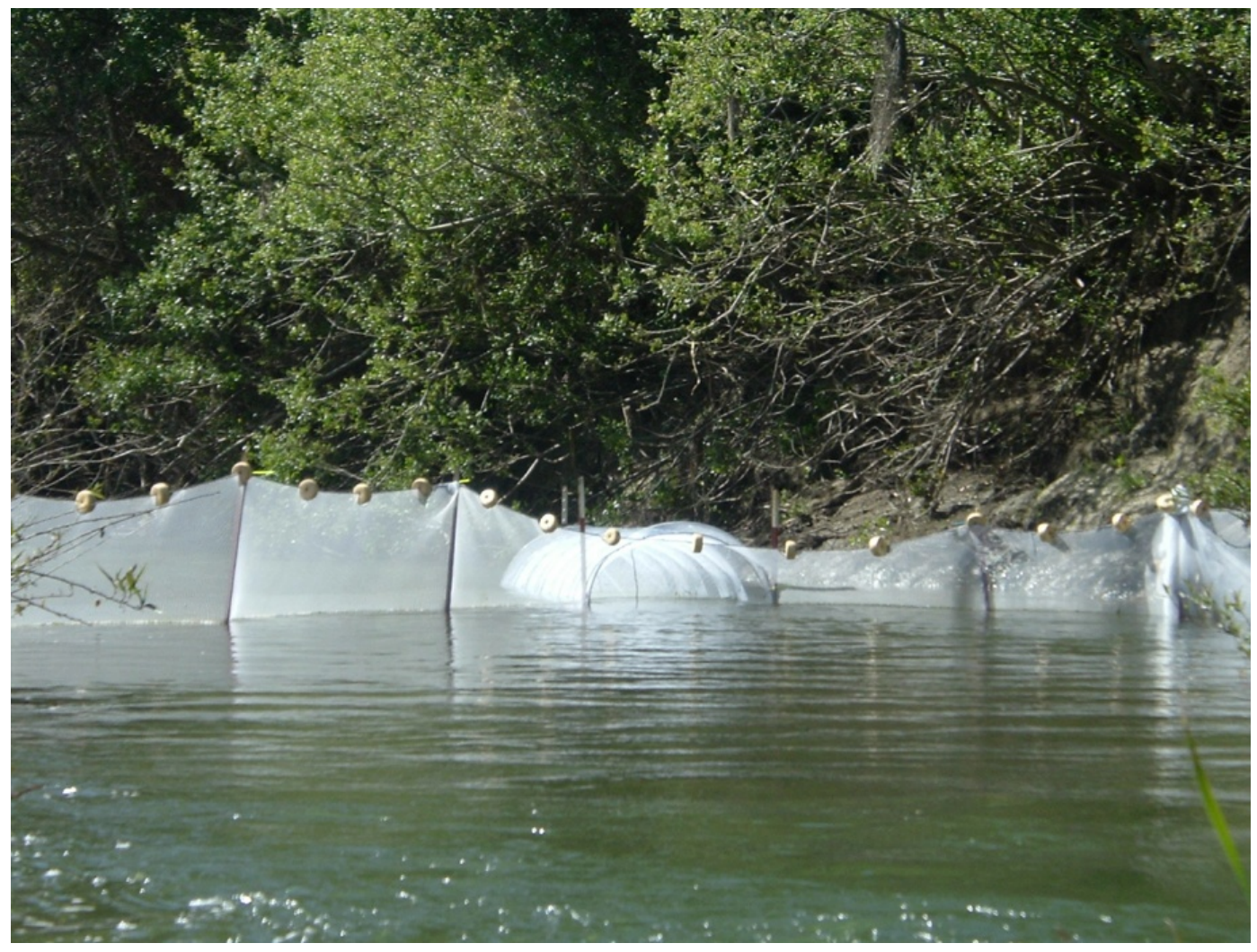

Figure 6. Out-migrant fyke net and weir setup on Santa Rosa Creek from April 18 to May 25, 2005. 


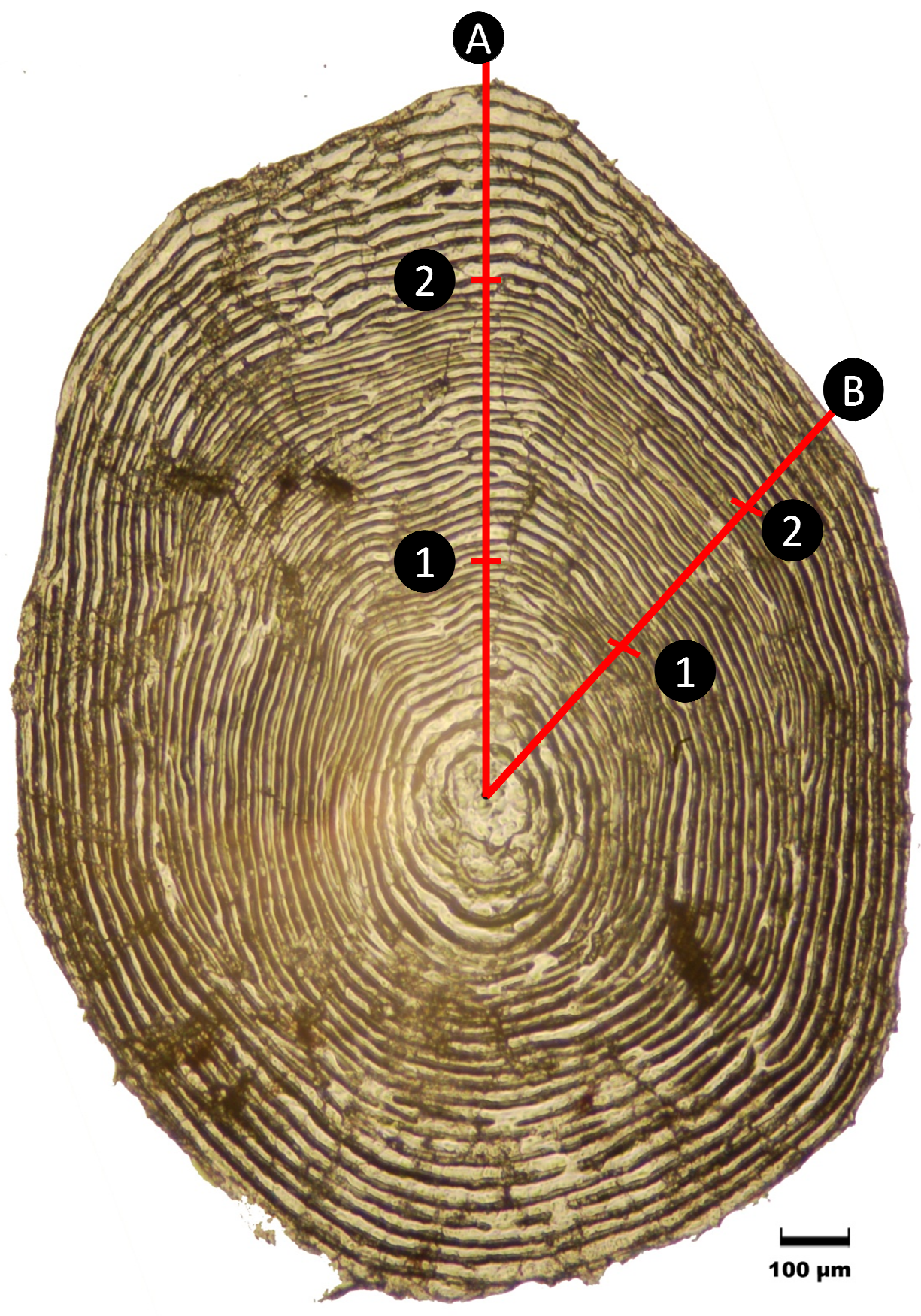

Figure 7. Image of an O. m. irideus scale used to interpret age. A. 90 degree radius line. B. 45 degree radius line. First annuli mark is denoted by the "1", the second by the " 2 ". 


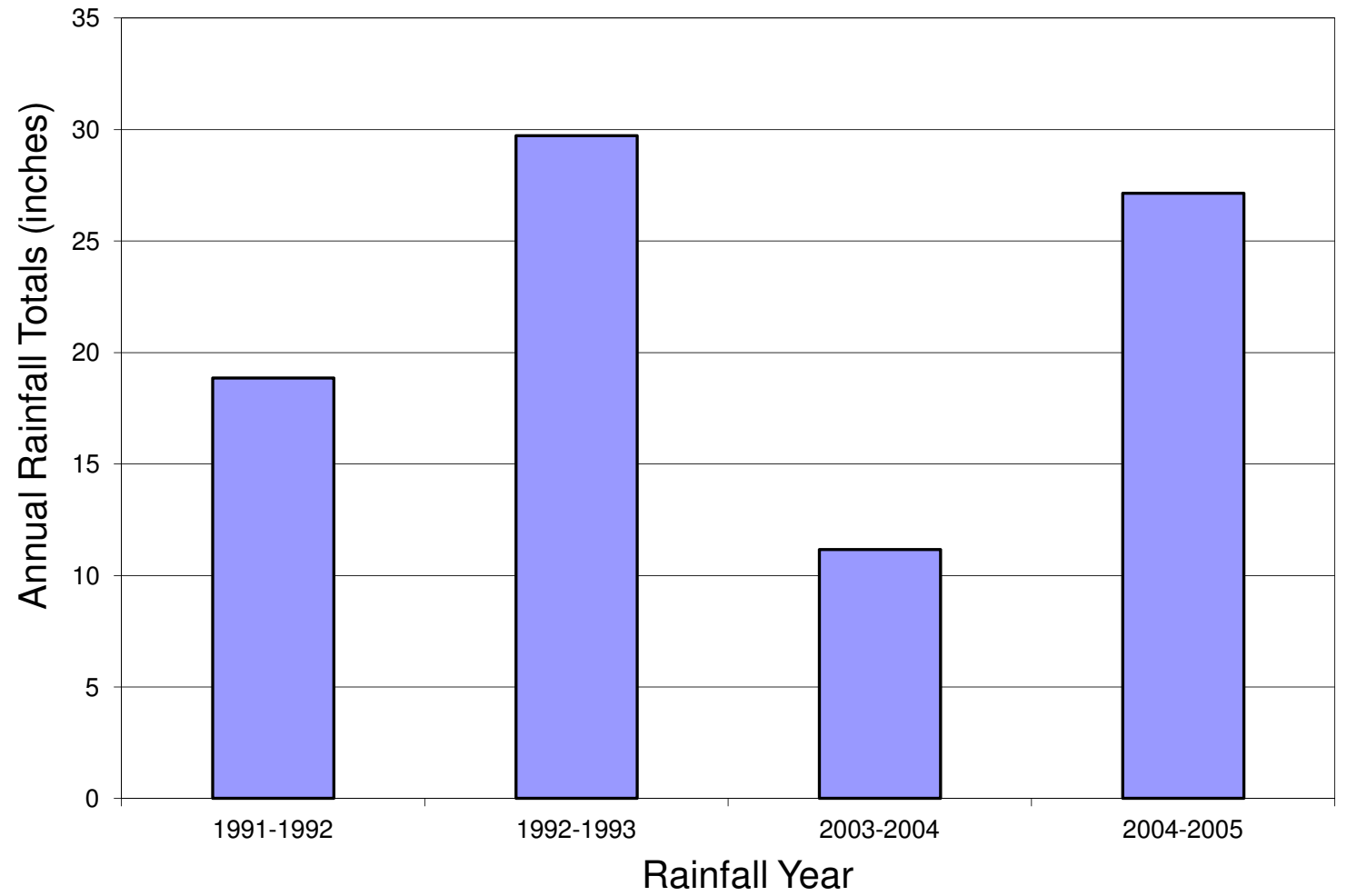

Figure 8. Annual rainfall totals in inches for Cambria, CA. (Tribune). 


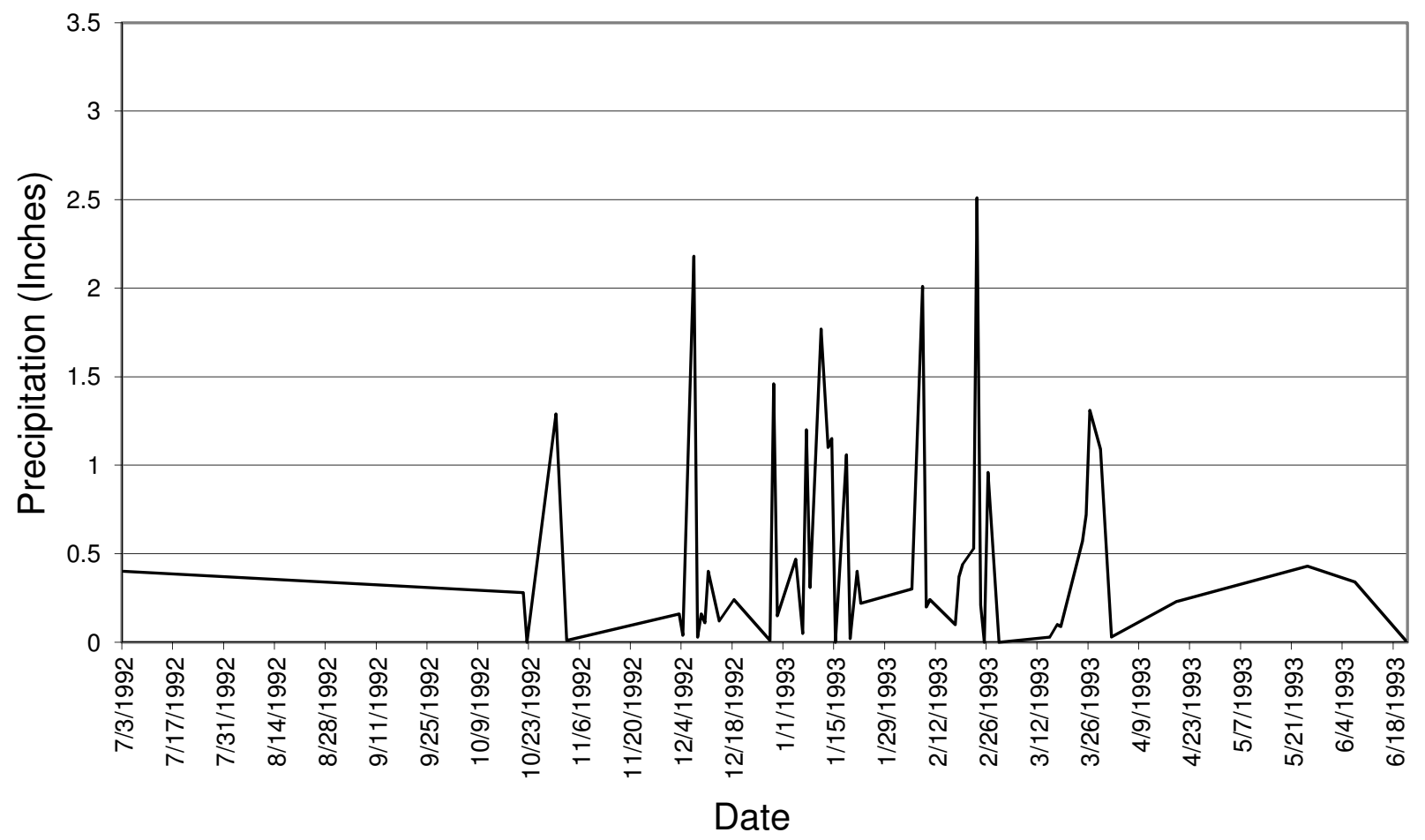

Figure 9. Precipitation amounts (inches) for Cambria, CA during the 1992-93 rain season (Tribune).

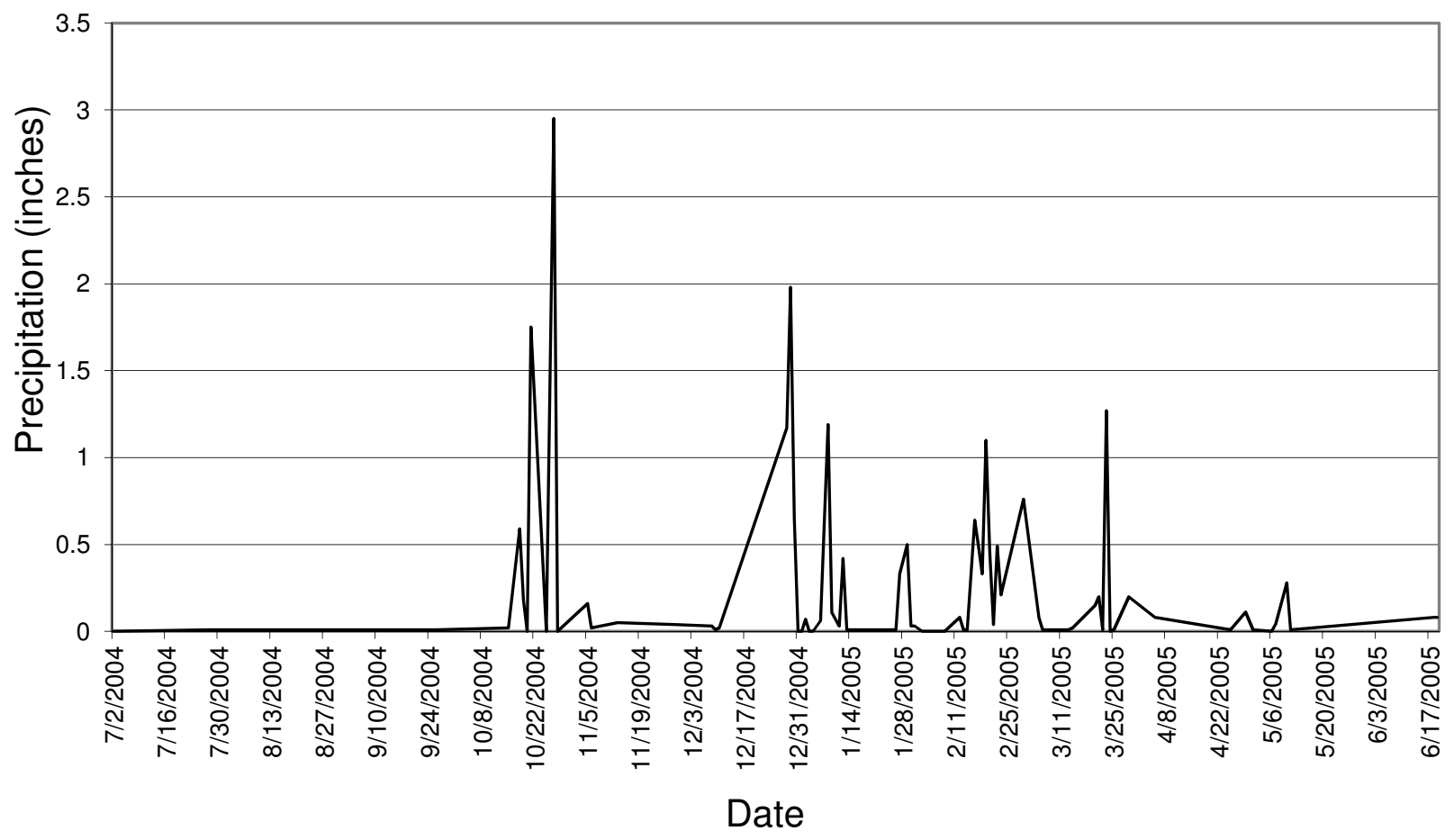

Figure 10. Precipitation amounts (inches) for Cambria, CA during the 2004-05 rain season (Tribune). 

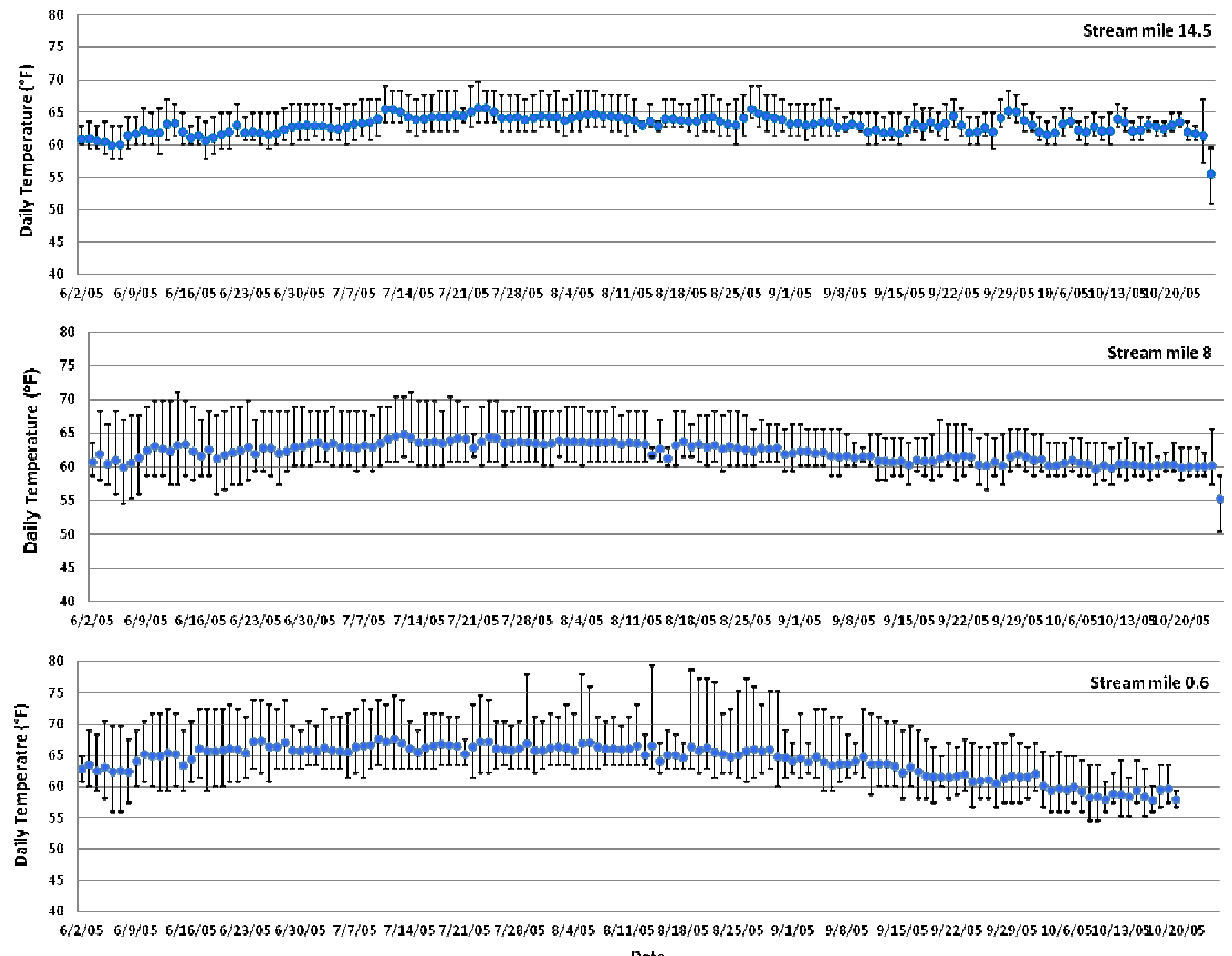

Date

Figure 11. Average daily temperature with max and min range at three different sites on Santa Rosa Creek from June 2 to Oct. $25,2005$. 


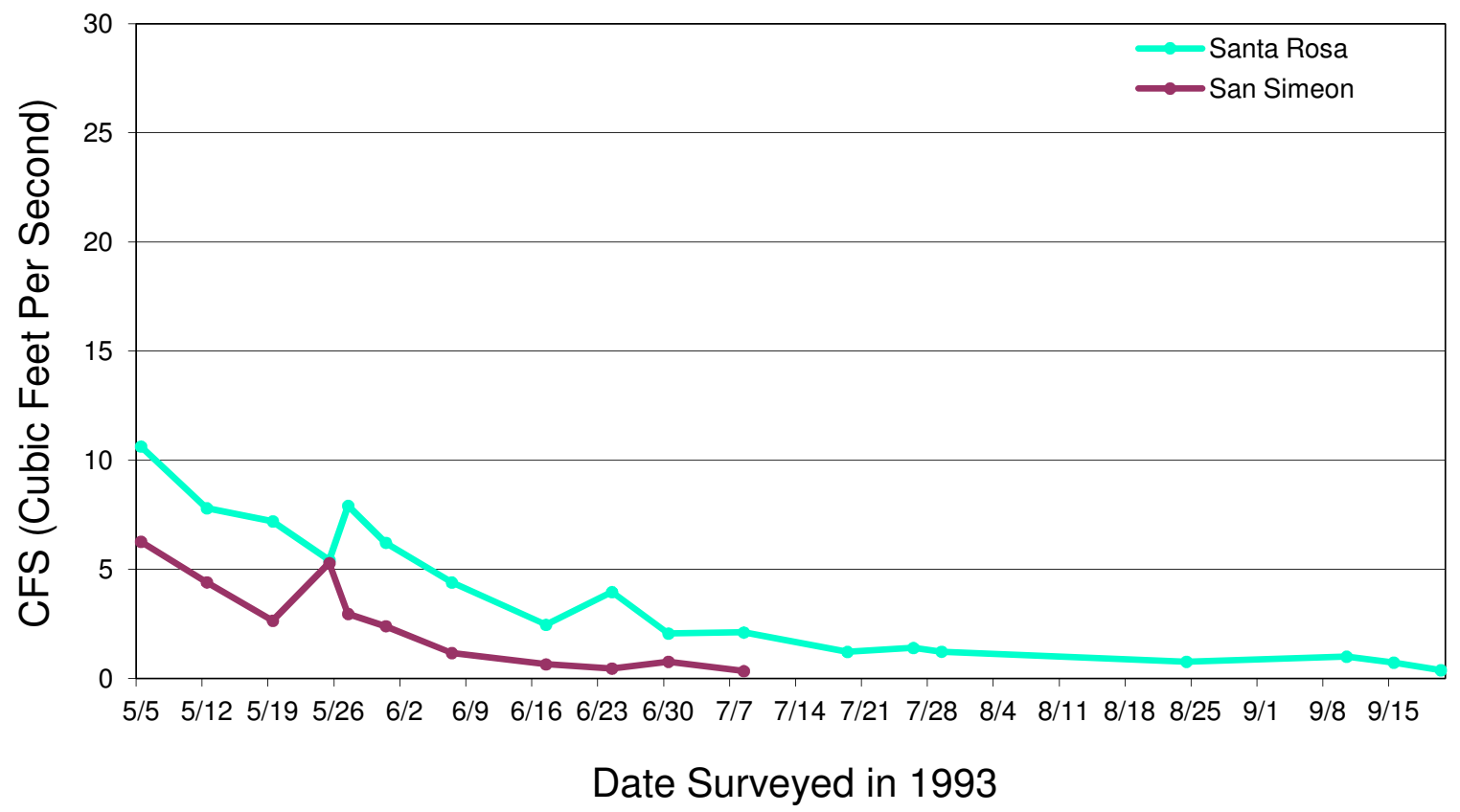

Figure 12. Stream flow measurements for San Simeon and Santa Rosa Creeks during the 1993 field season.

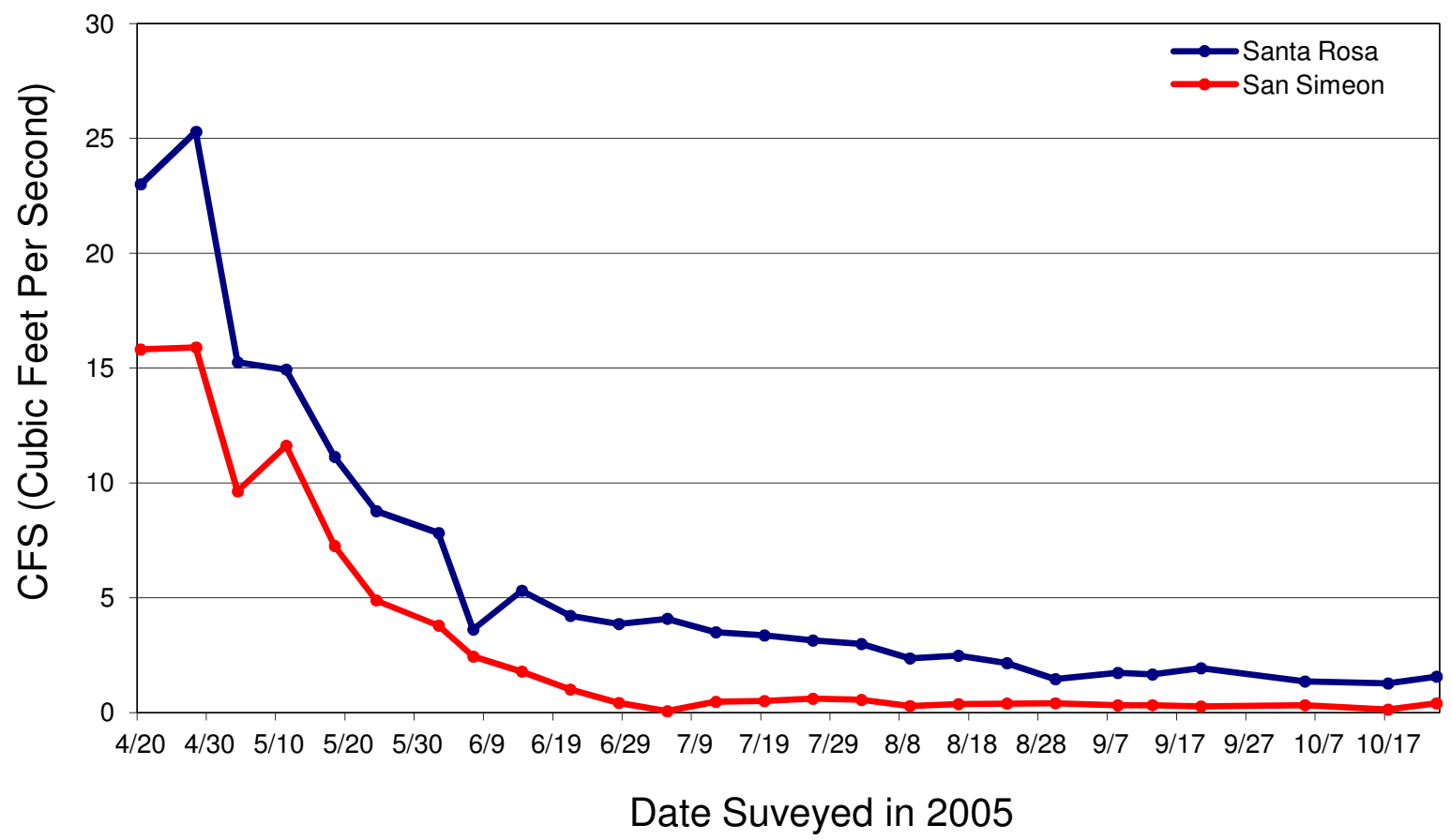

Figure 13. Stream flow measurements for San Simeon and Santa Rosa Creeks during the 2005 field season. 


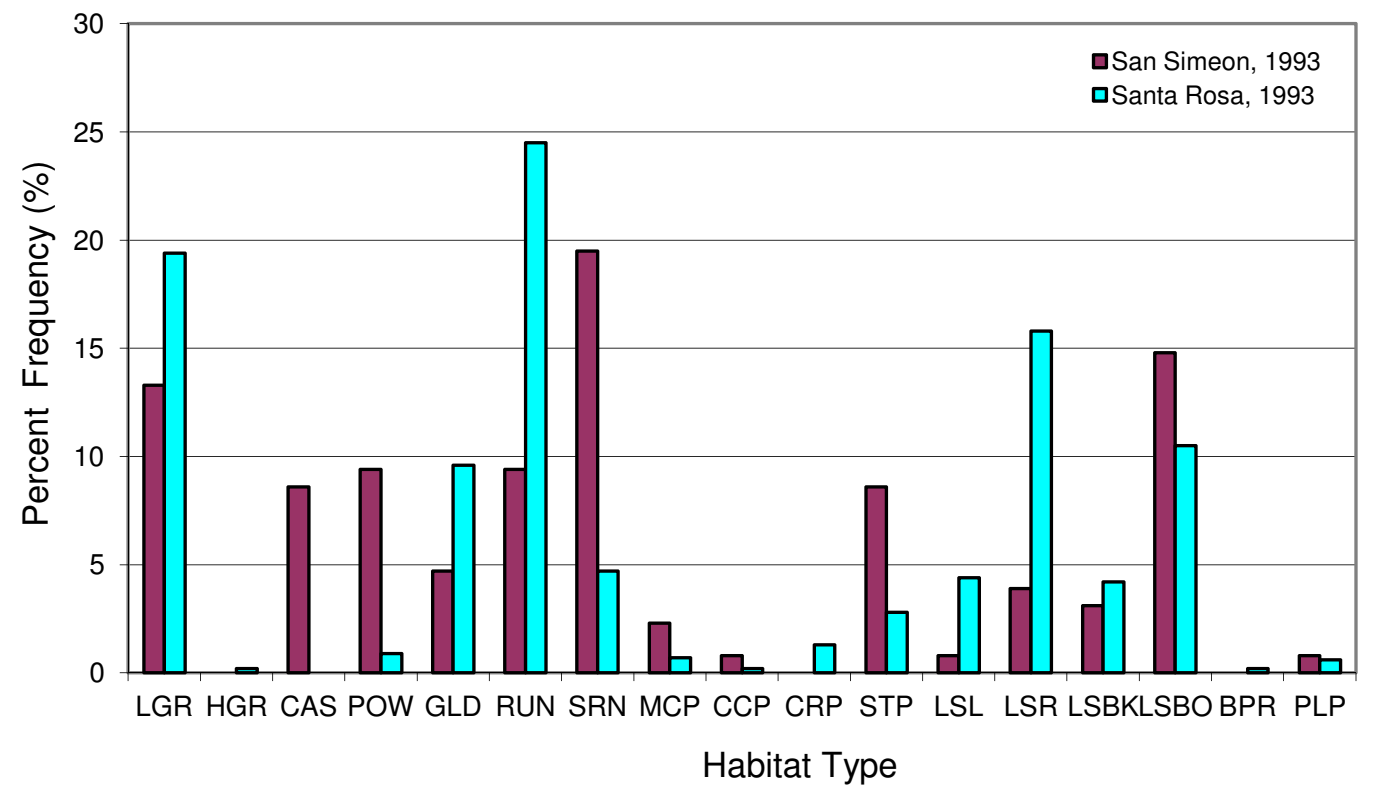

Figure 14. Percent frequency distribution of units identified during stream habitat mapping surveys on San Simeon $(\mathrm{N}=128)$ and Santa Rosa Creek $(\mathrm{N}=1018)$ in 1993. San Simeon includes units from stream mile 4.1 to 5.9 .

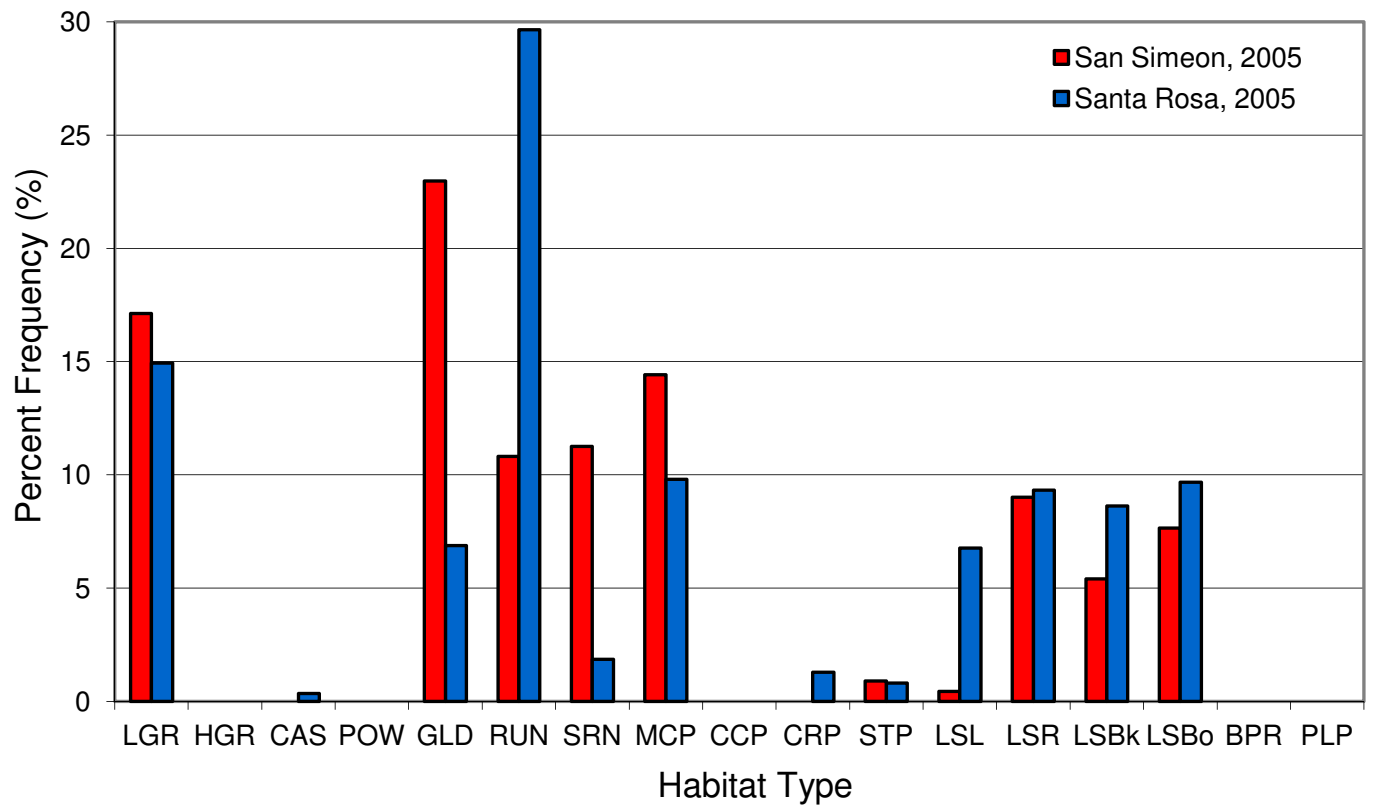

Figure 15. Percent frequency distribution of units identified during stream habitat mapping surveys on San Simeon (N=222) and Santa Rosa Creek (N=857) in 2005. 


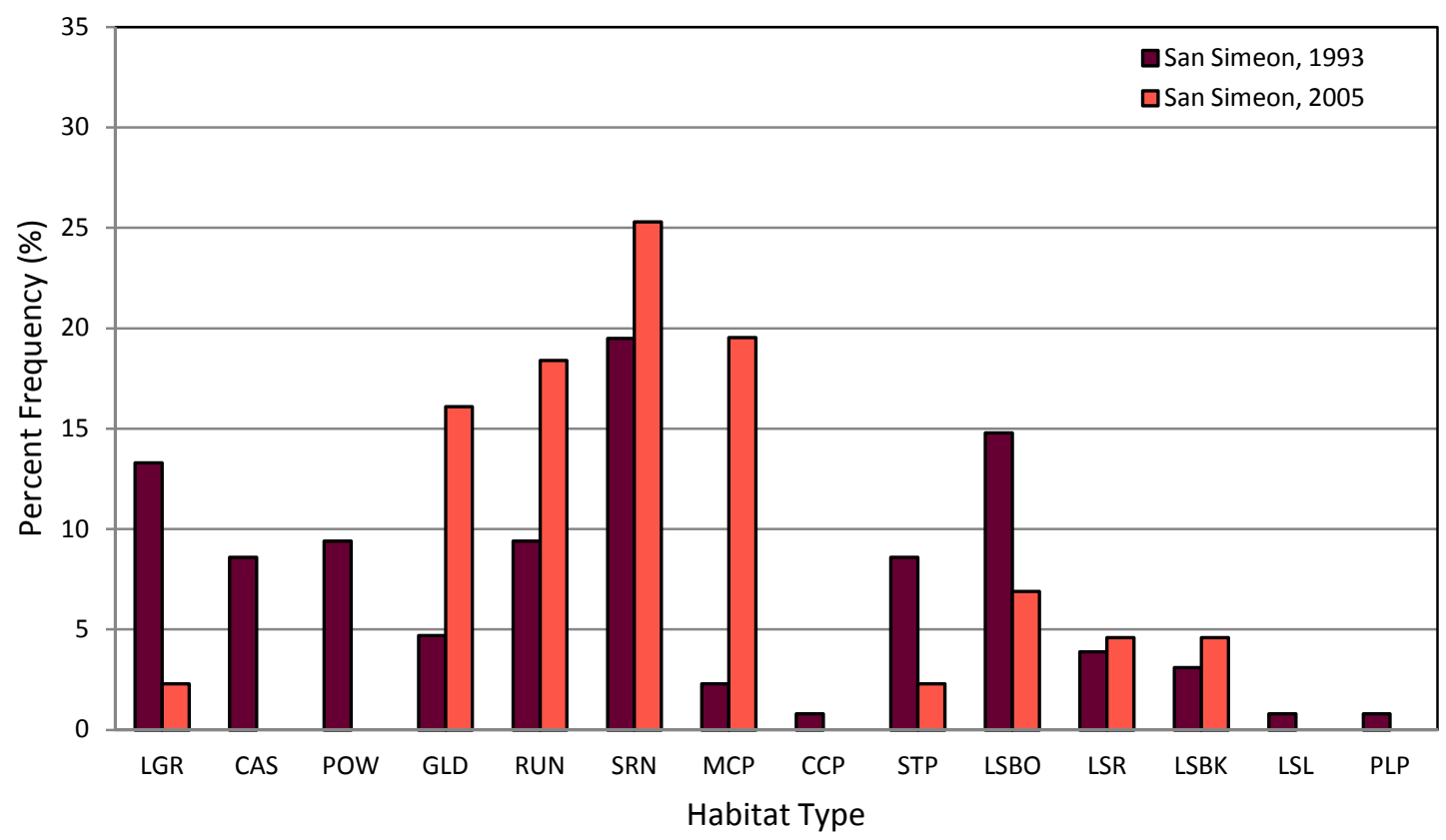

Figure 16. Percent frequency distribution of habitat units observed on San Simeon Creek in 1993 $(\mathrm{N}=128)$ and $2005(\mathrm{~N}=87)$. Both data sets include units from the confluence with Steiner Creek upstream to the boulder falls.

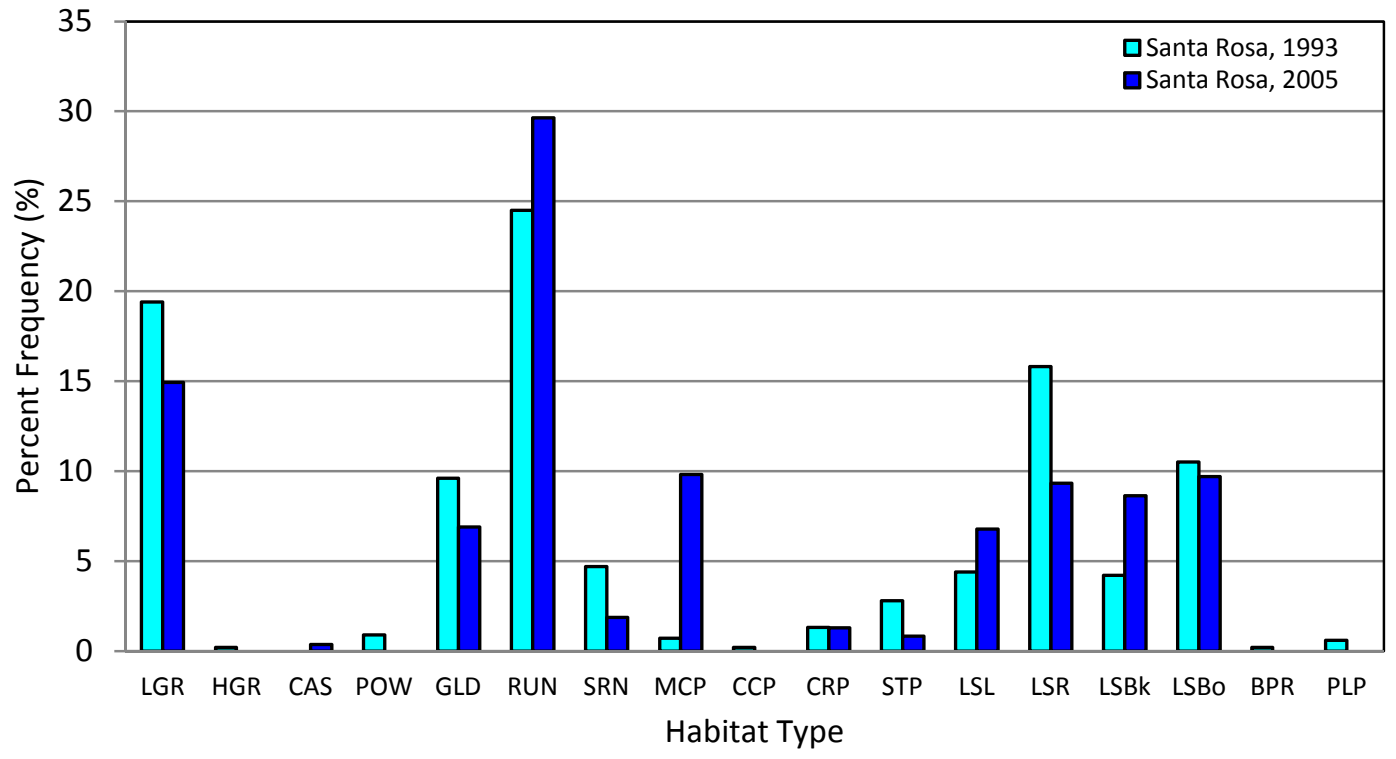

Figure 17. Percent frequency distribution of habitat units observed on Santa Rosa Creek in 1993 ( $\mathrm{N}=1018)$ and $2005(\mathrm{~N}=857)$. 


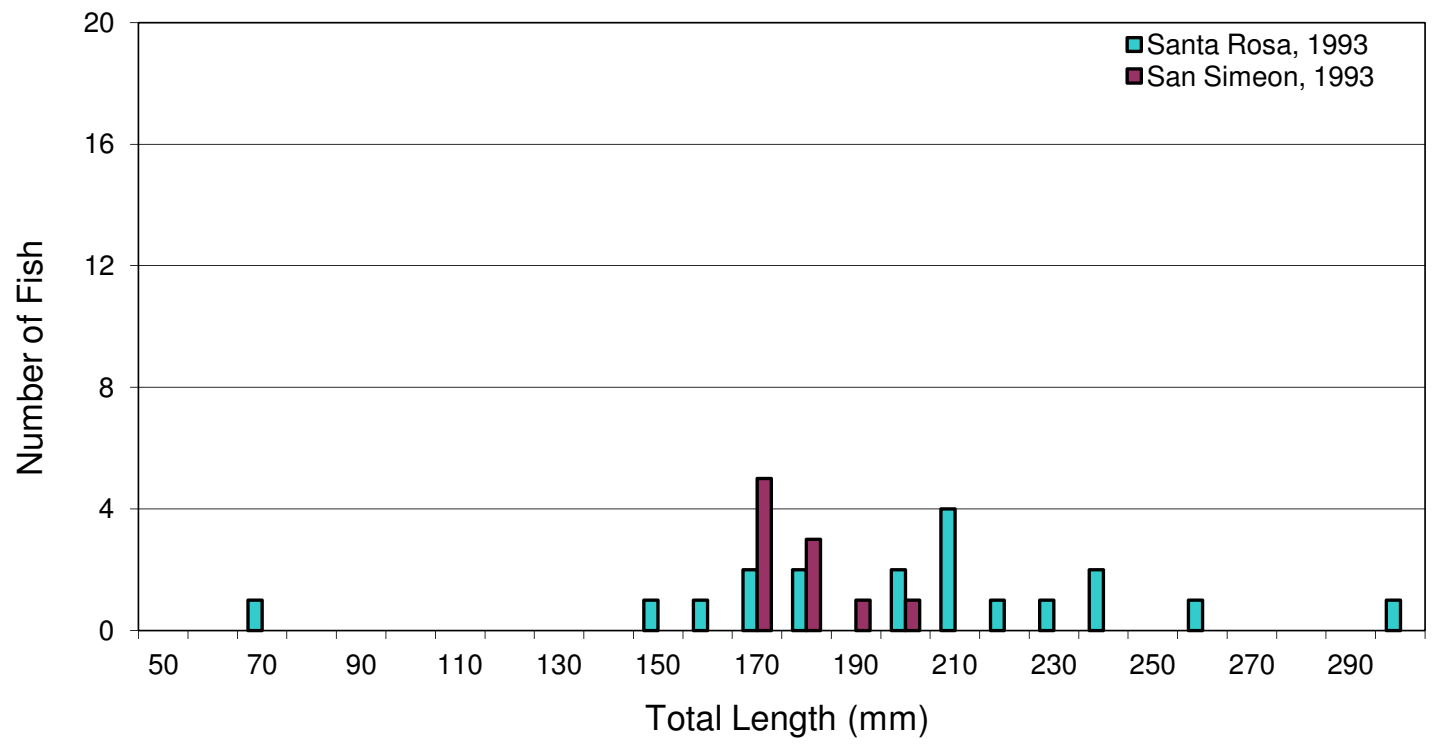

Figure 18. Total length distribution of steelhead caught in the out-migrant traps on San Simeon and Santa Rosa Creeks during the 1993 field season. N=10 on San Simeon, N=19 on Santa Rosa (not including 3 kelts).

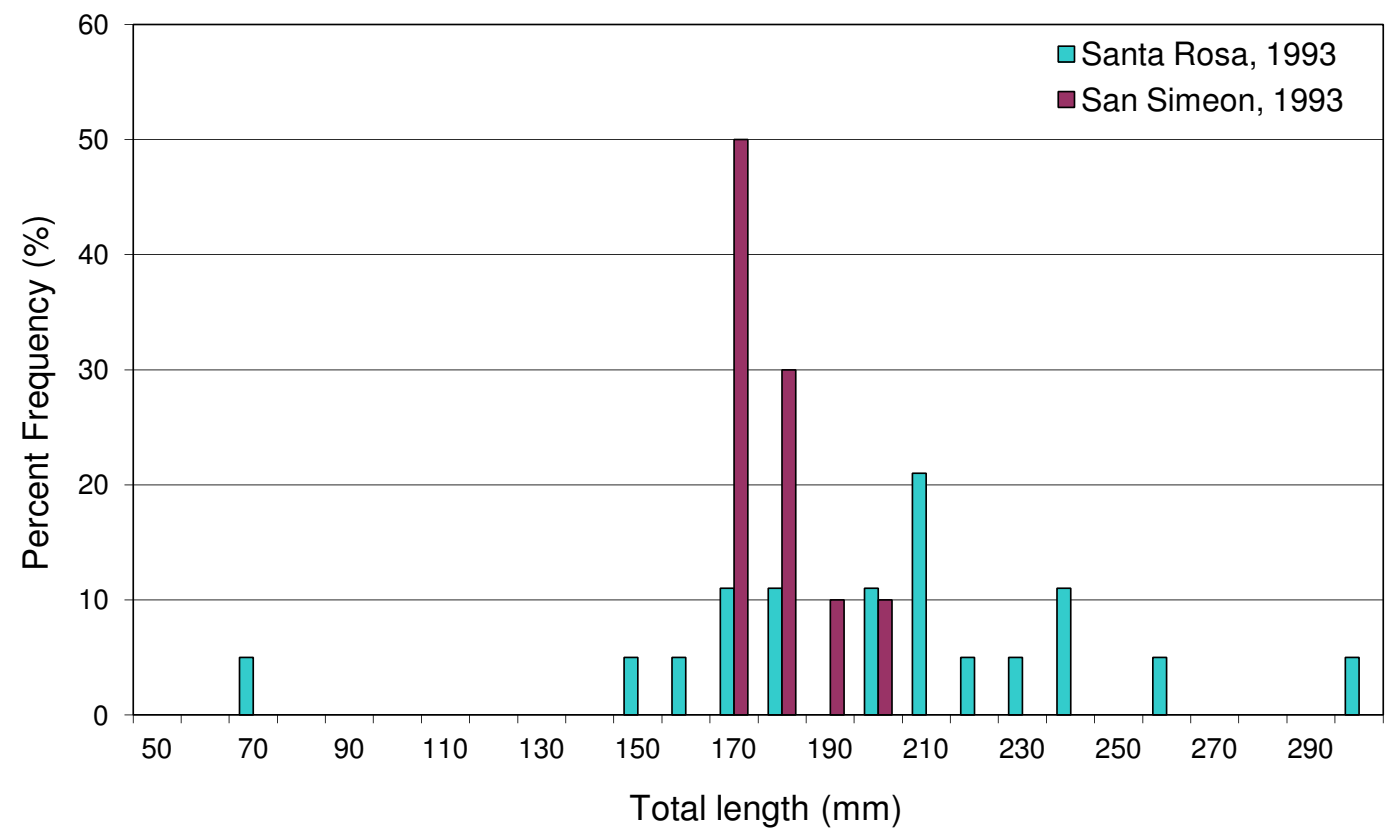

Figure 19. The percent frequency distribution of total lengths of steelhead caught in the out-migrant traps on San Simeon and Santa Rosa Creeks during the 1993 field season. N=10 on San Simeon, N=19 on Santa Rosa (not including 3 kelts). 


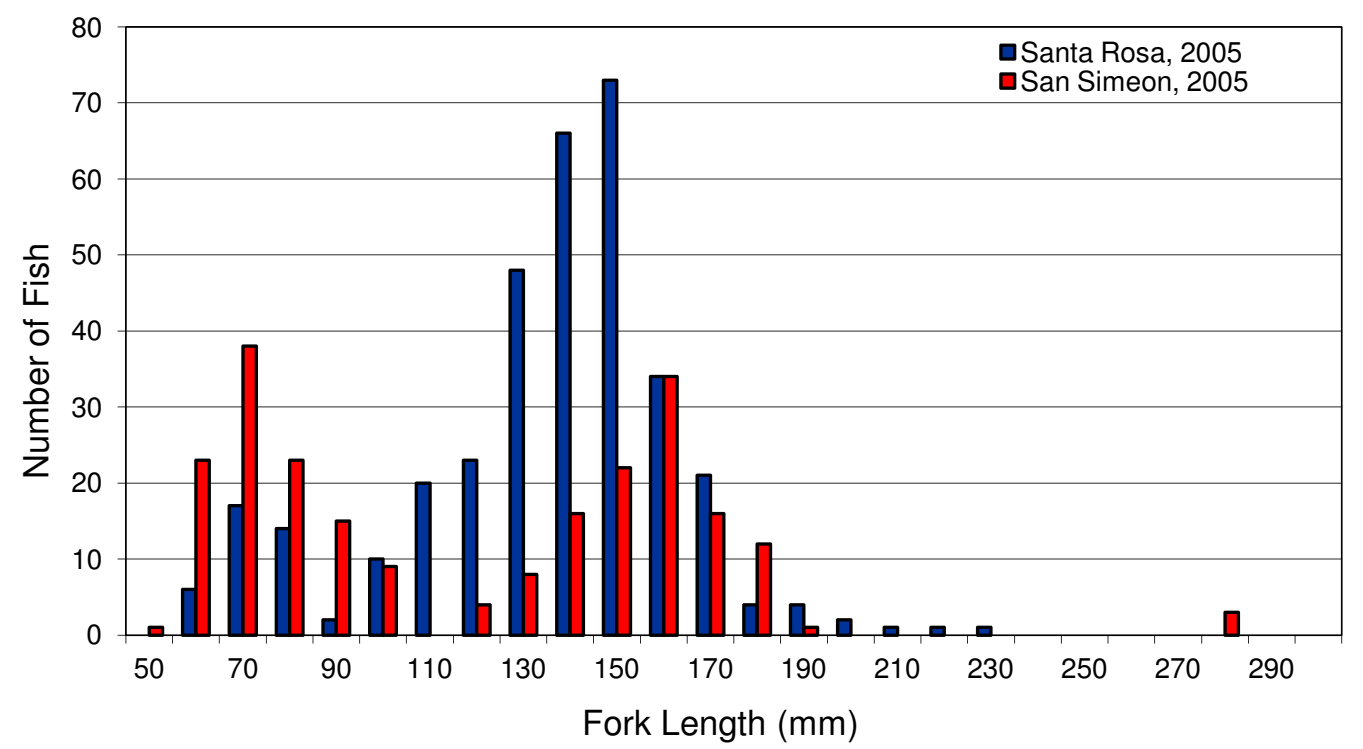

Figure 20. The fork length frequency distribution of steelhead caught in the out-migrant traps on San Simeon and Santa Rosa Creeks during the 2005 field season. N=225 on San Simeon, N=347 on Santa Rosa.

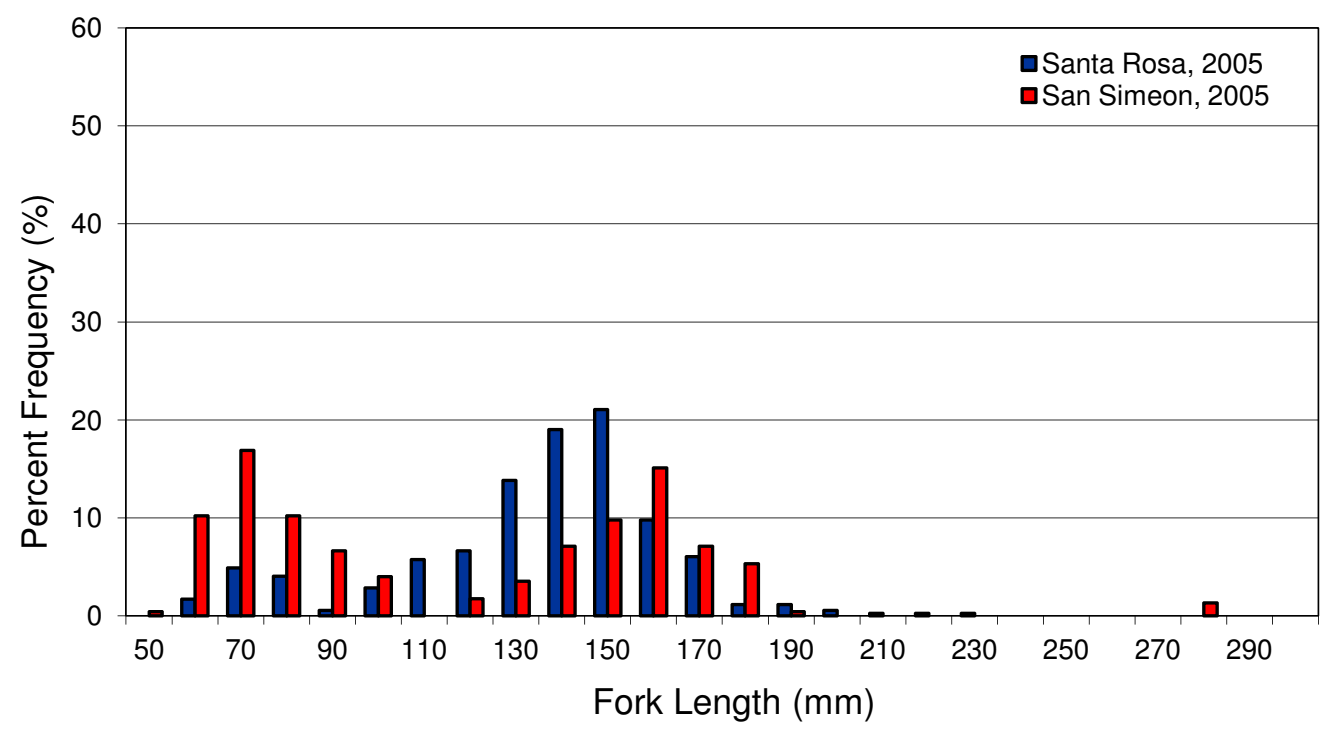

Figure 21. The percent frequency distribution of fork lengths of steelhead caught in the out-migrant traps on San Simeon and Santa Rosa Creeks during the 2005 field season. N=225 on San Simeon, N=347 on Santa Rosa. 


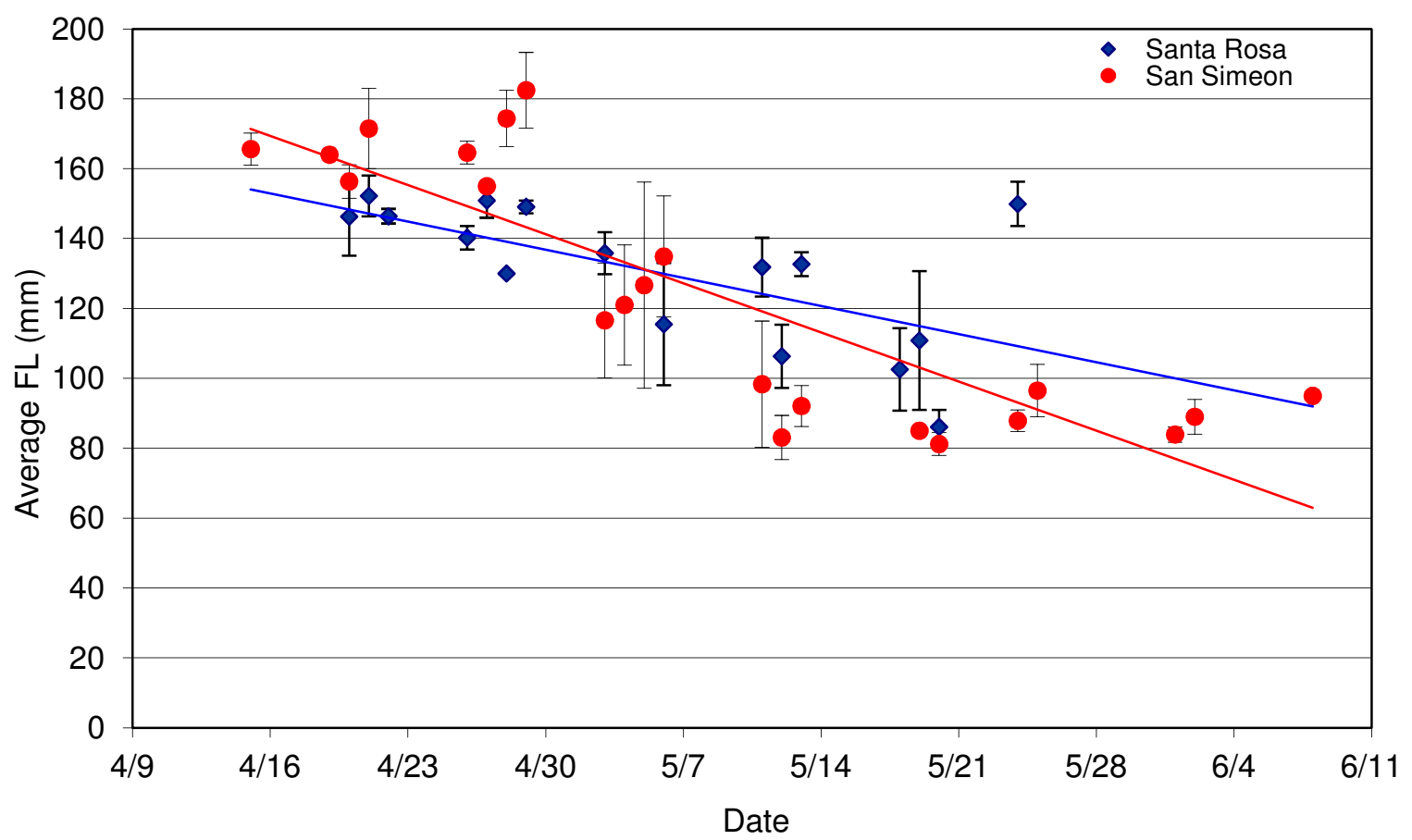

Figure 22. The average fork length of steelhead caught in out-migrant traps on San Simeon and Santa Rosa Creeks during the 2005 trapping season. N=214 on San Simeon, N=347 on Santa Rosa. Standard error bars included. 


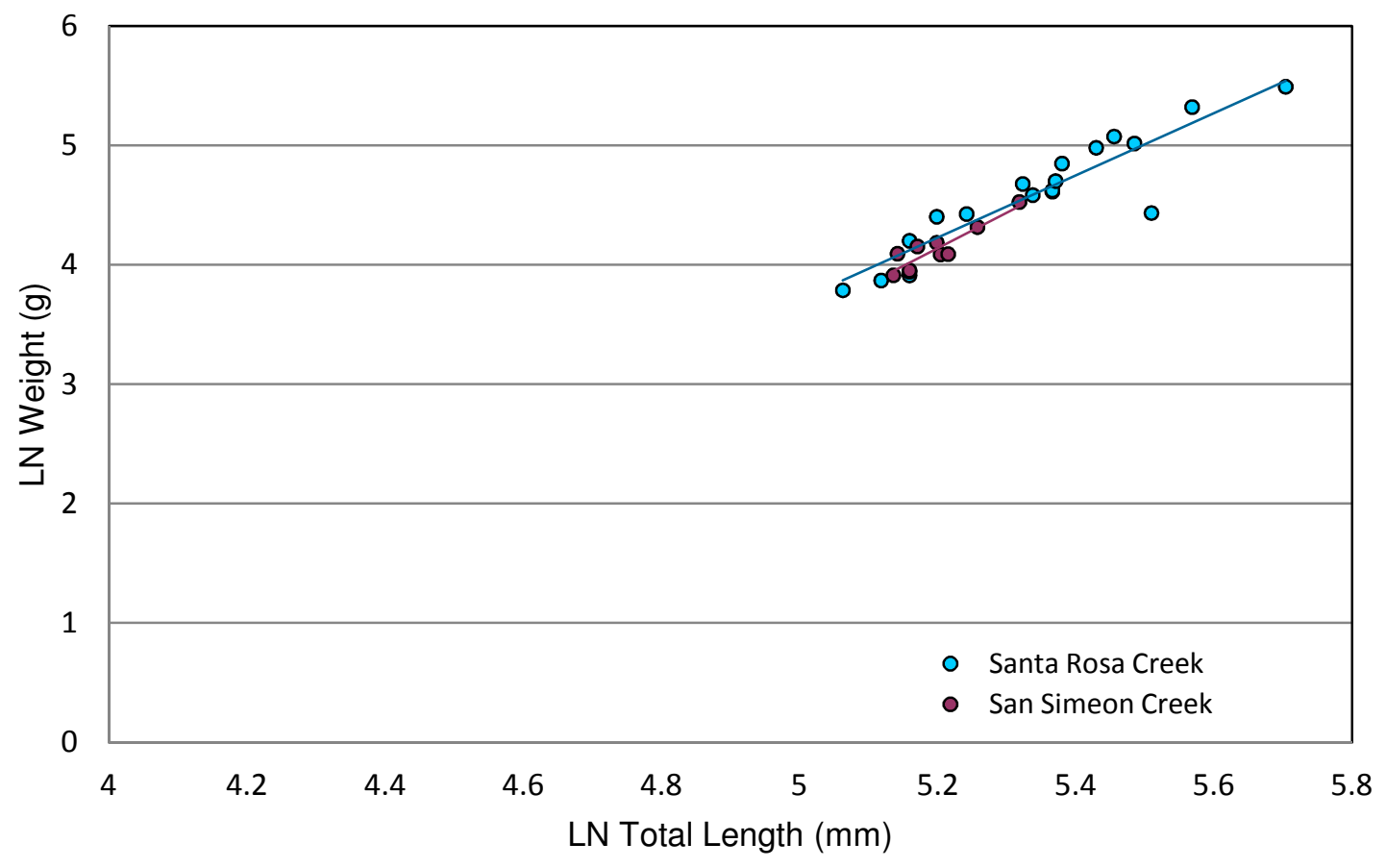

Figure 23. Scatterplot/regression analysis of the natural log of total lengths versus the natural log of weights for steelhead caught in the out-migrant trap on San Simeon Creek in $1993(\mathrm{~N}=10$, $\left.W=-11.38+2.985 T L, R^{2}=0.826\right)$ and Santa Rosa Creek $(N=18$, two outliers removed. $W=-9.317+$ 2.605TL. $\left.R^{2}=0.844\right)$. 


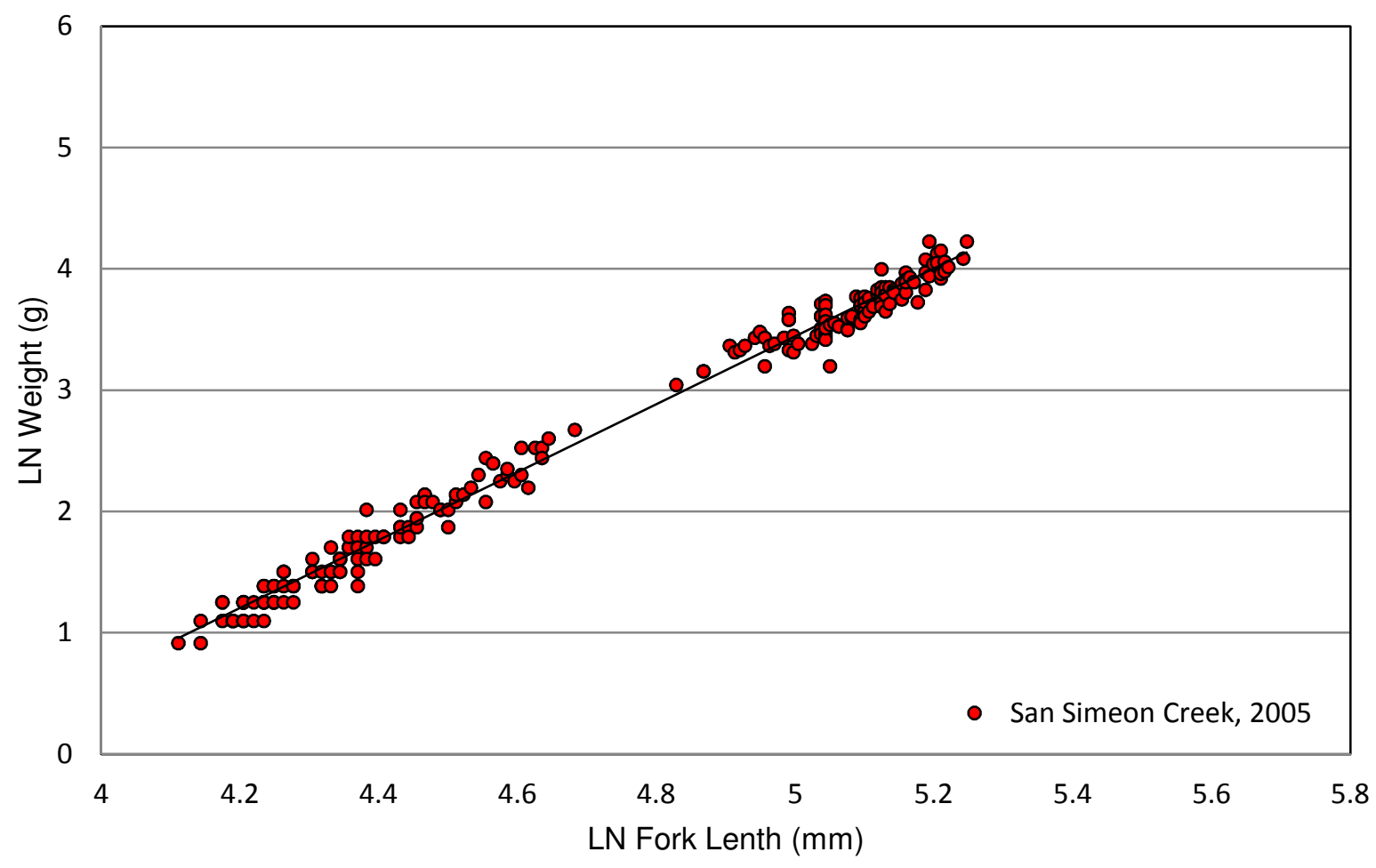

Figure 24. Scatterplot/regression analysis of the natural log of fork lengths versus the natural log of weights for steelhead caught in the out-migrant trap on San Simeon Creek in 2005. $N=210$; four outliers were removed from this graph. $W=-10.56+2.800 F L . R^{2}=0.99$. 


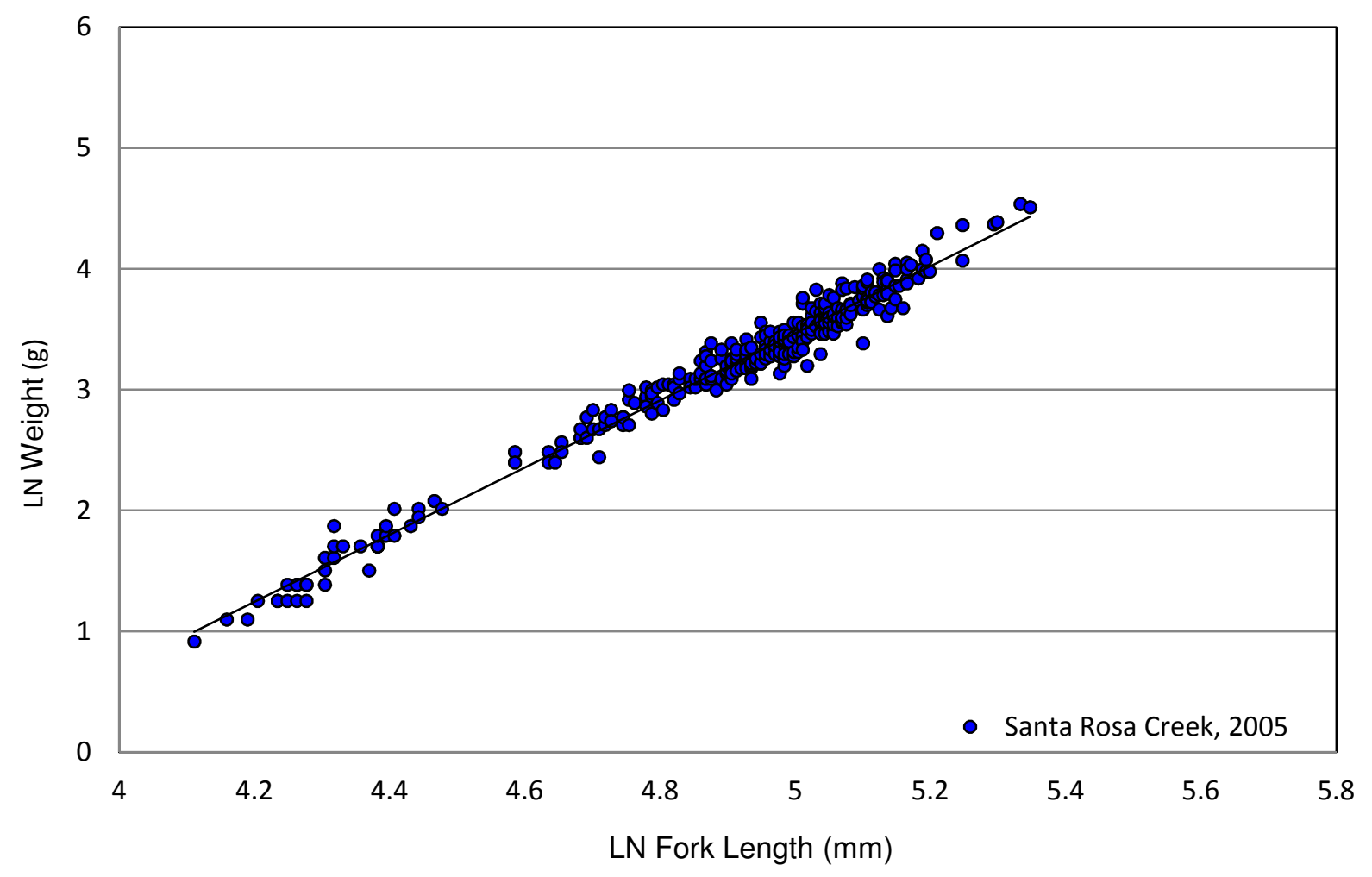

Figure 25. Scatterplot/regression analysis of the natural log of fork lengths versus the natural log of weights for steelhead caught in the out-migrant trap on Santa Rosa Creek in 2005. N=341; two outliers were removed from this graph. $\mathrm{W}=-10.43+2.780 \mathrm{FL} . \mathrm{R}^{2}=0.977$. 


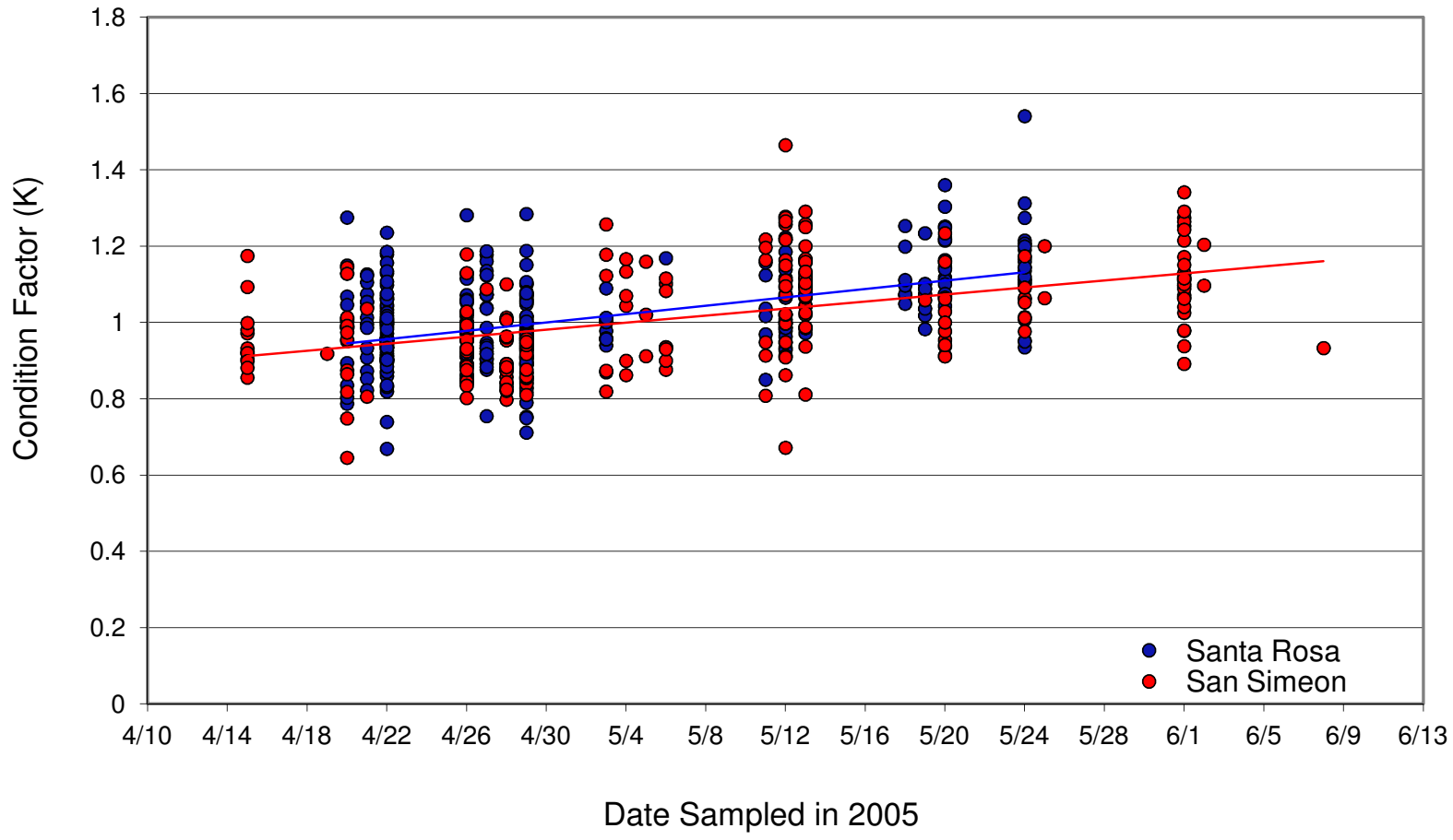

Figure 26. Distribution of steelhead condition factors $(\mathrm{K})$ by date trapped on San Simeon and Santa Rosa creeks, 2005. $\mathrm{N}=214$ on San Simeon creek, $\mathrm{N}=343$ on Santa Rosa creek. 


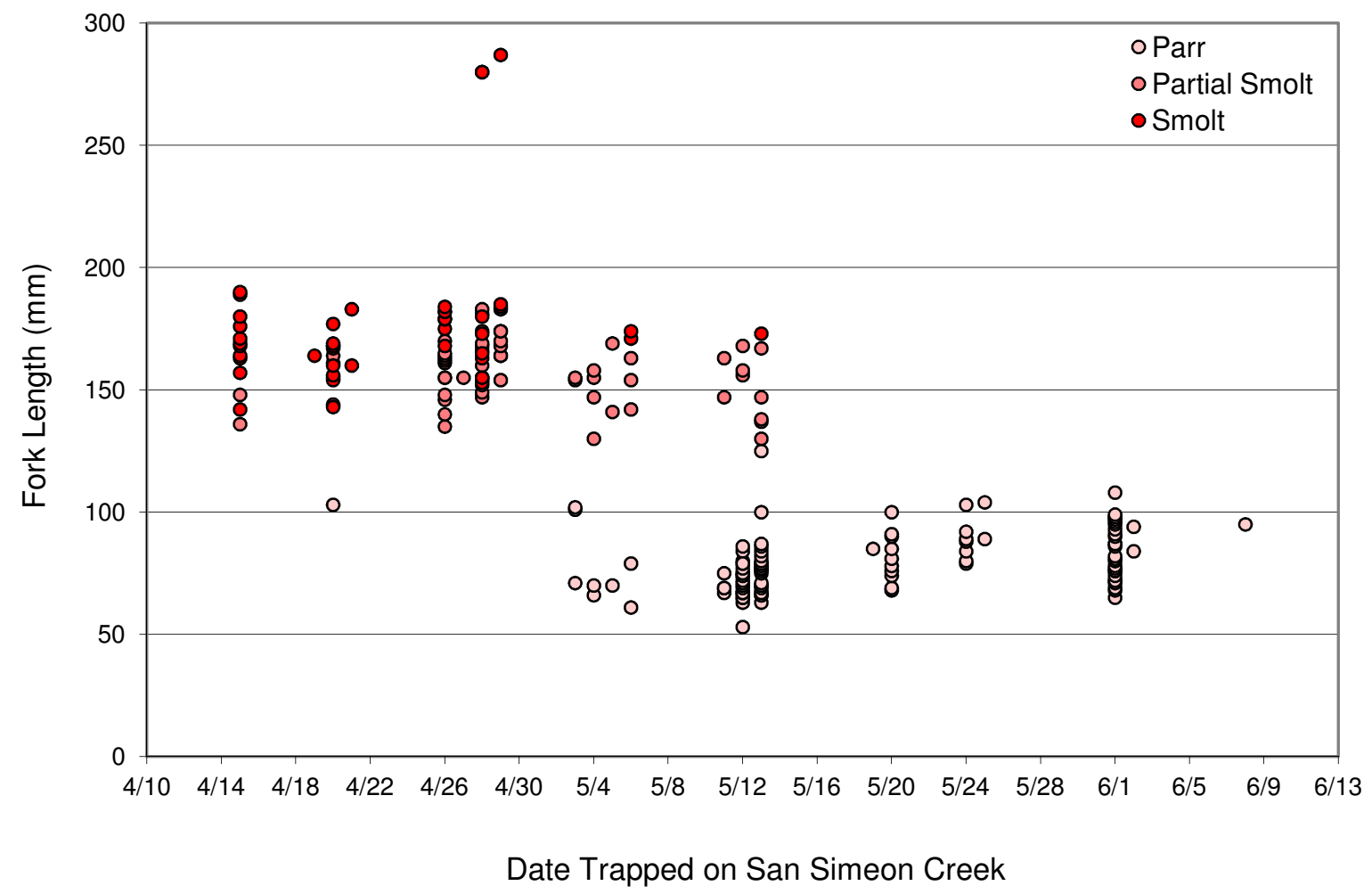

Figure 27. Fork lengths of parr, partial smolt, and smolt captured on San Simeon Creek throughout the trapping season in 2005. $\mathrm{N}=214$. 


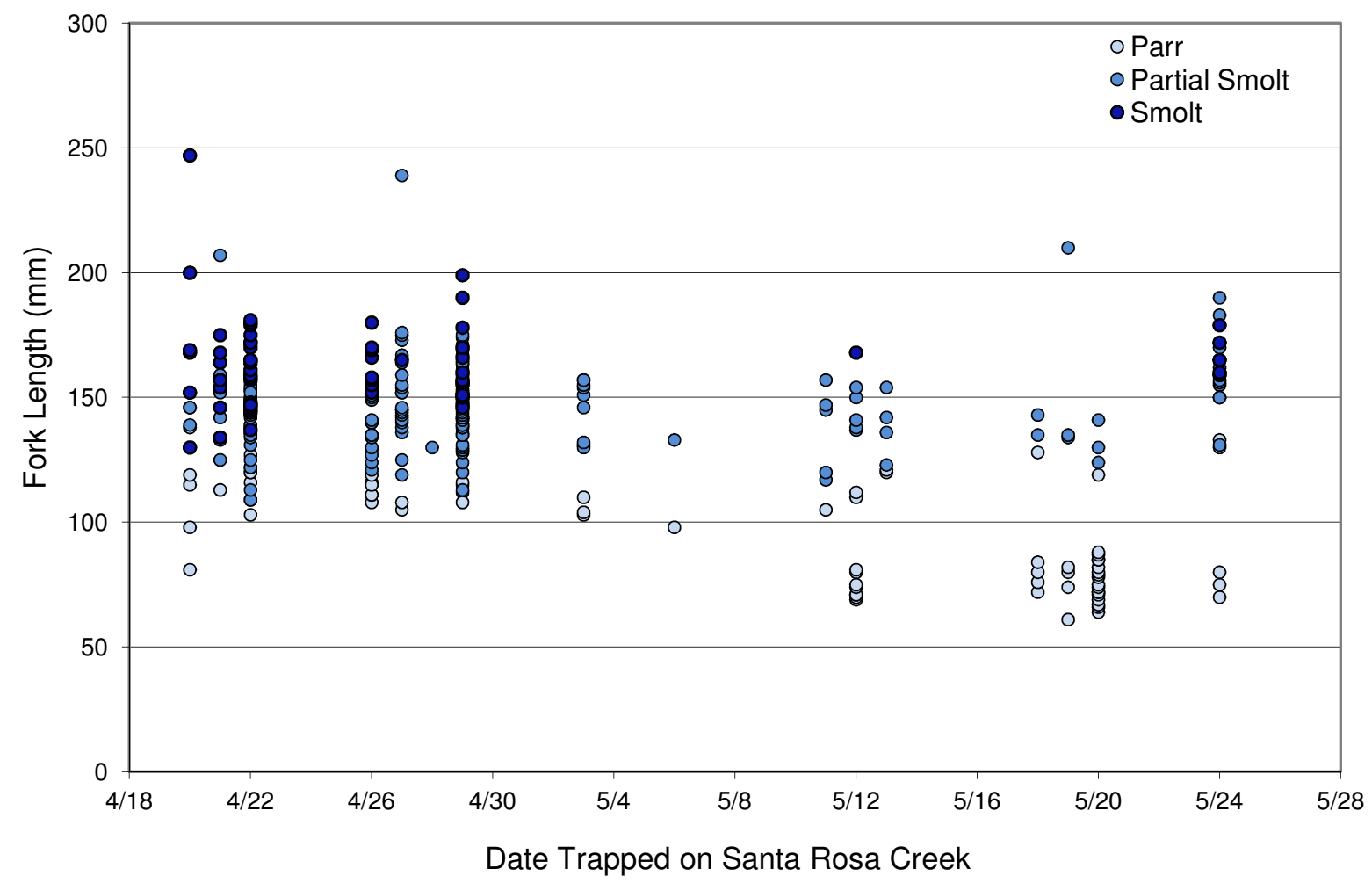

Figure 28. Fork lengths of parr, partial smolt, and smolt captured on Santa Rosa Creek throughout the trapping season in 2005. $\mathrm{N}=343$. 


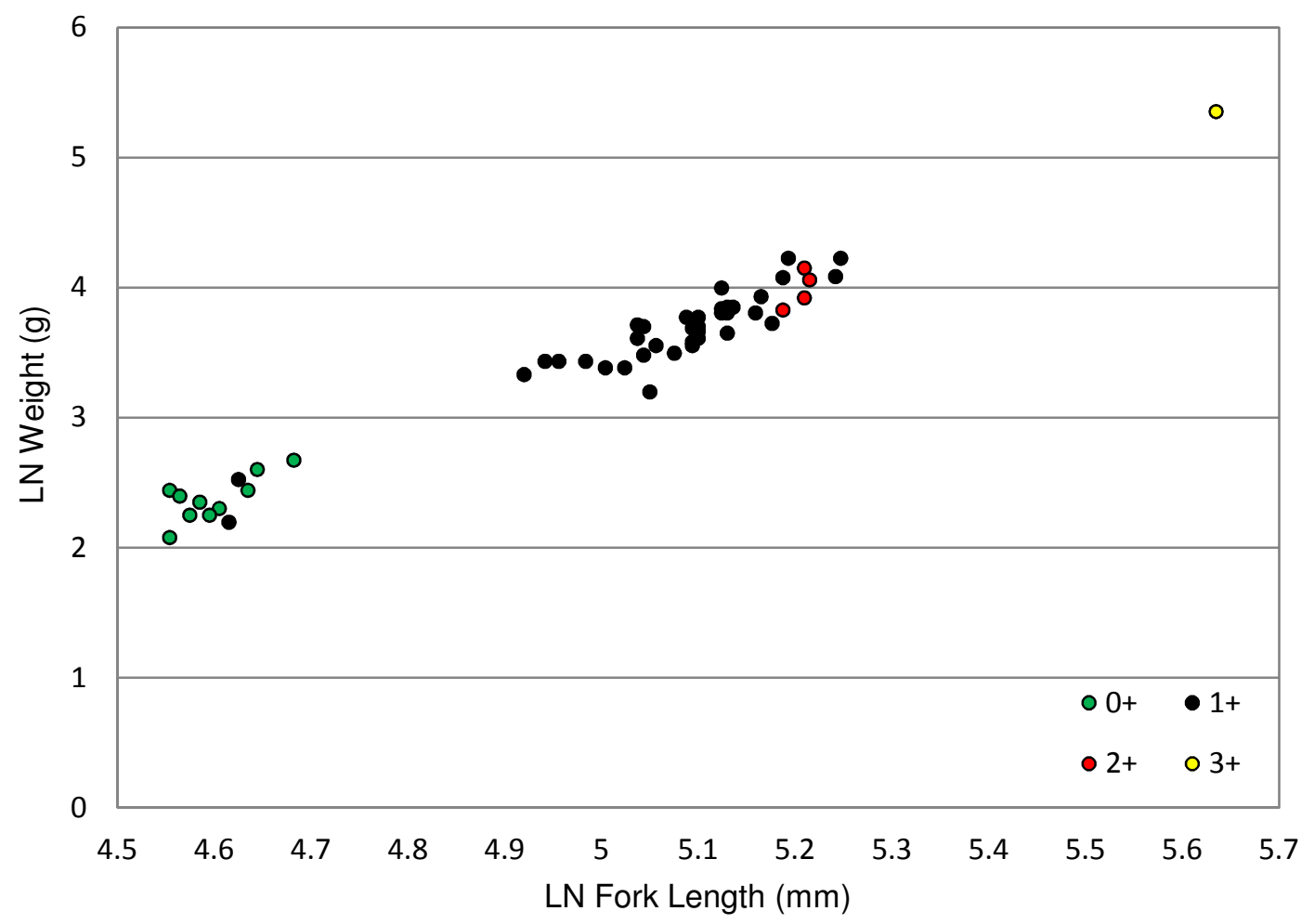

Figure 29. The natural log fork length by the natural log weight for age $0+, 1+, 2+$, and $3+$ steelhead trapped on San Simeon Creek, 2005. N=55. 


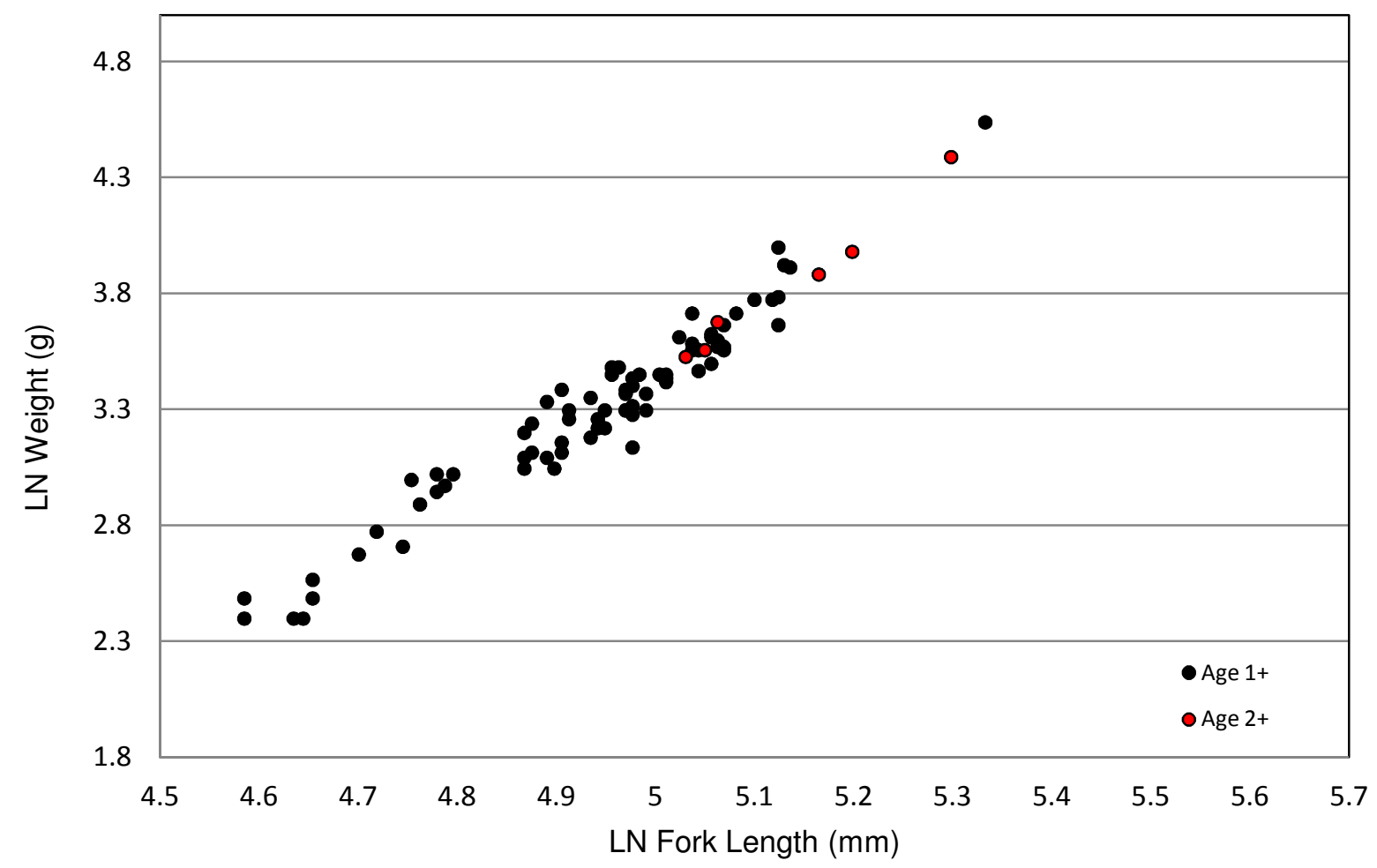

Figure 30. The natural log of fork length by the natural log of weight for age $1+, 2+$ steelhead trapped on Santa Rosa Creek, 2005. N=82. Age 0+ fish were not included in this analysis due to unreadable scale samples. 


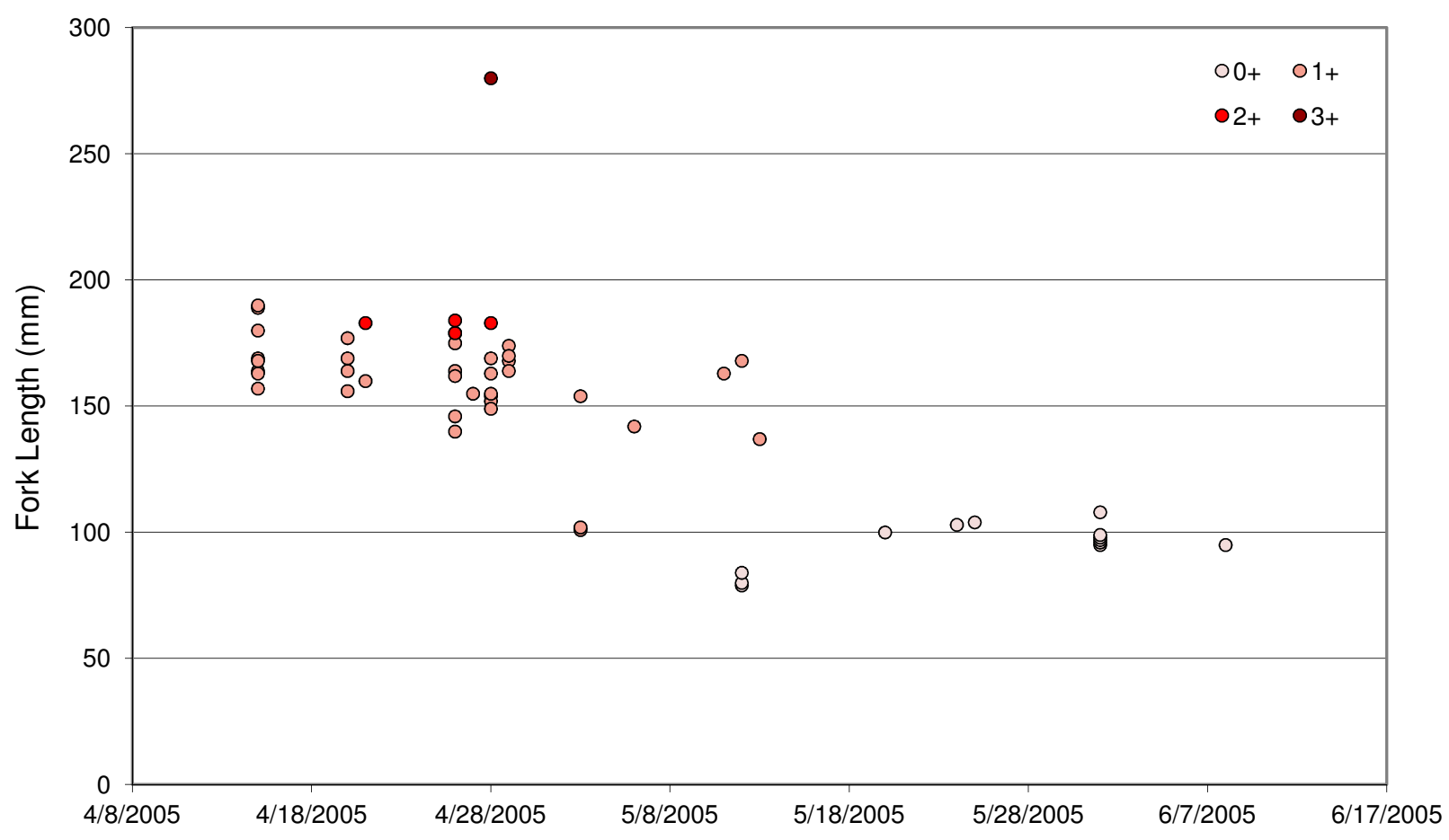

Date trapped on San Simeon Creek, 2005

Figure 31. Fork length by date distribution of age $0+, 1+, 2+, 3+$ steelhead caught on San Simeon Creek in 2005. $\mathrm{N}=55$. 


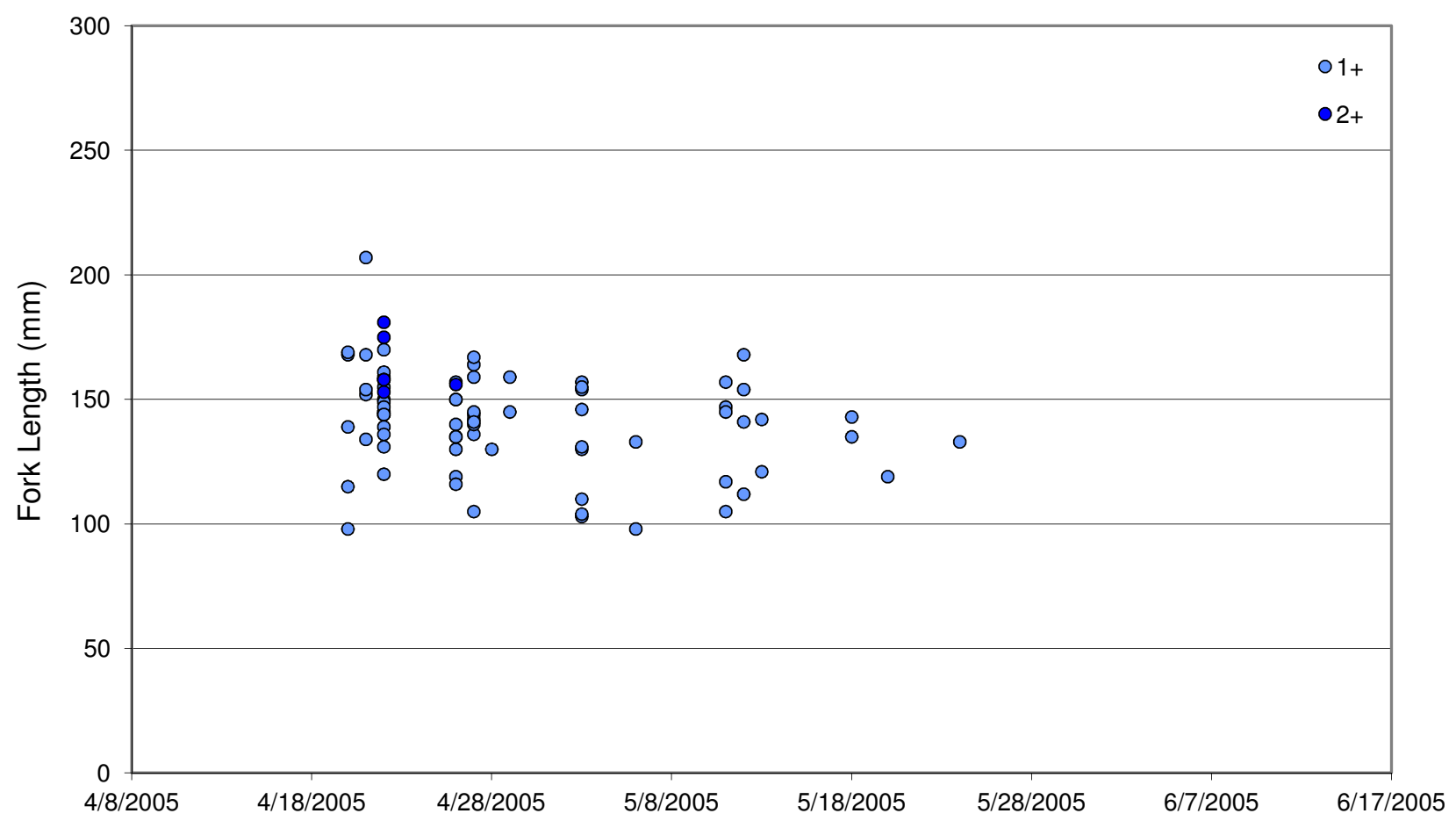

Date Trapped on Santa Rosa Creek, 2005

Figure 32. Fork length by date distribution of age 1+, 2+ steelhead caught on Santa Rosa Creek in 2005. $\mathrm{N}=82$. 


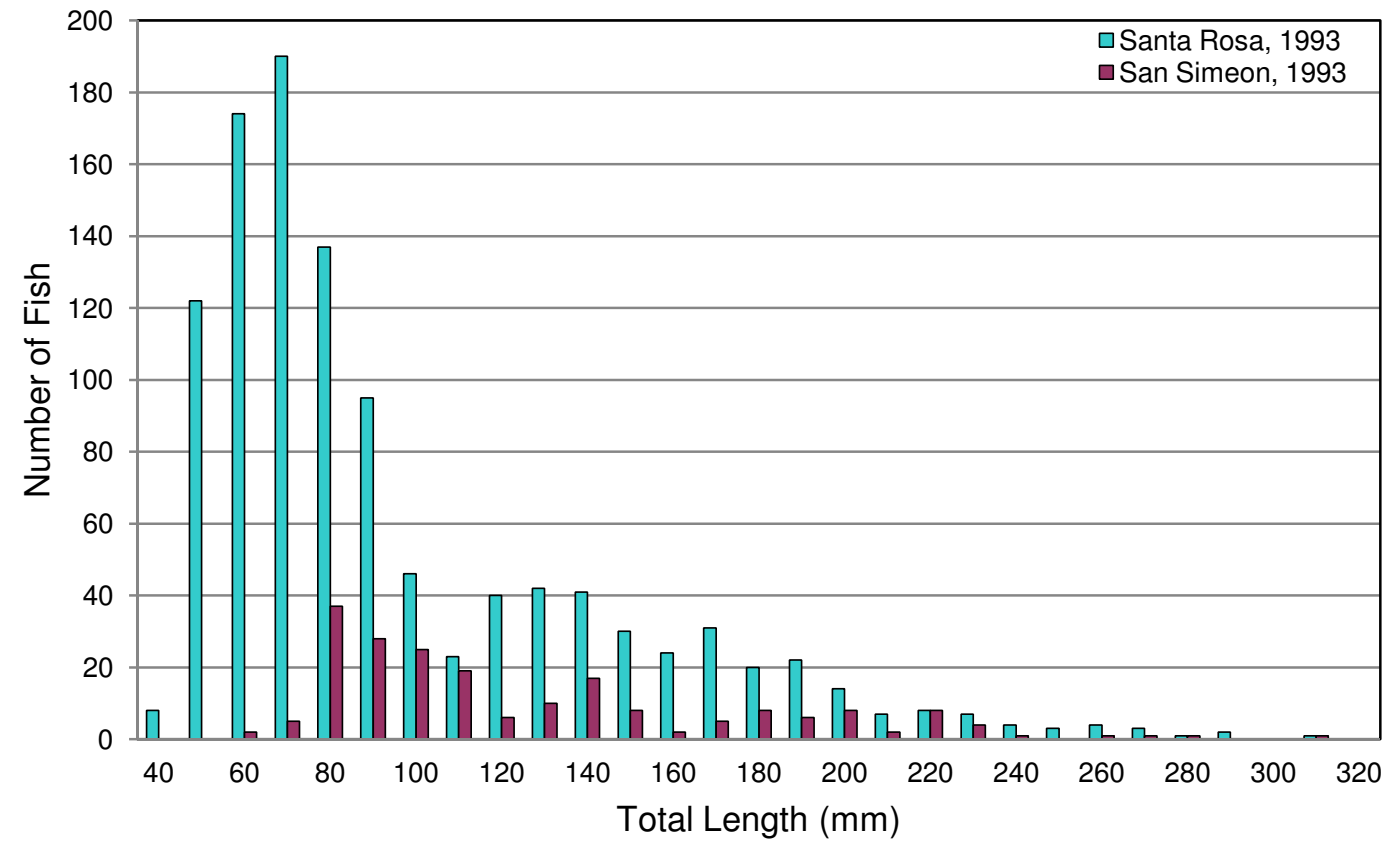

Figure 33. Total length distribution of steelhead electrofished from San Simeon $(N=205)$ and Santa Rosa $(\mathrm{N}=1099)$ Creeks in 1993.

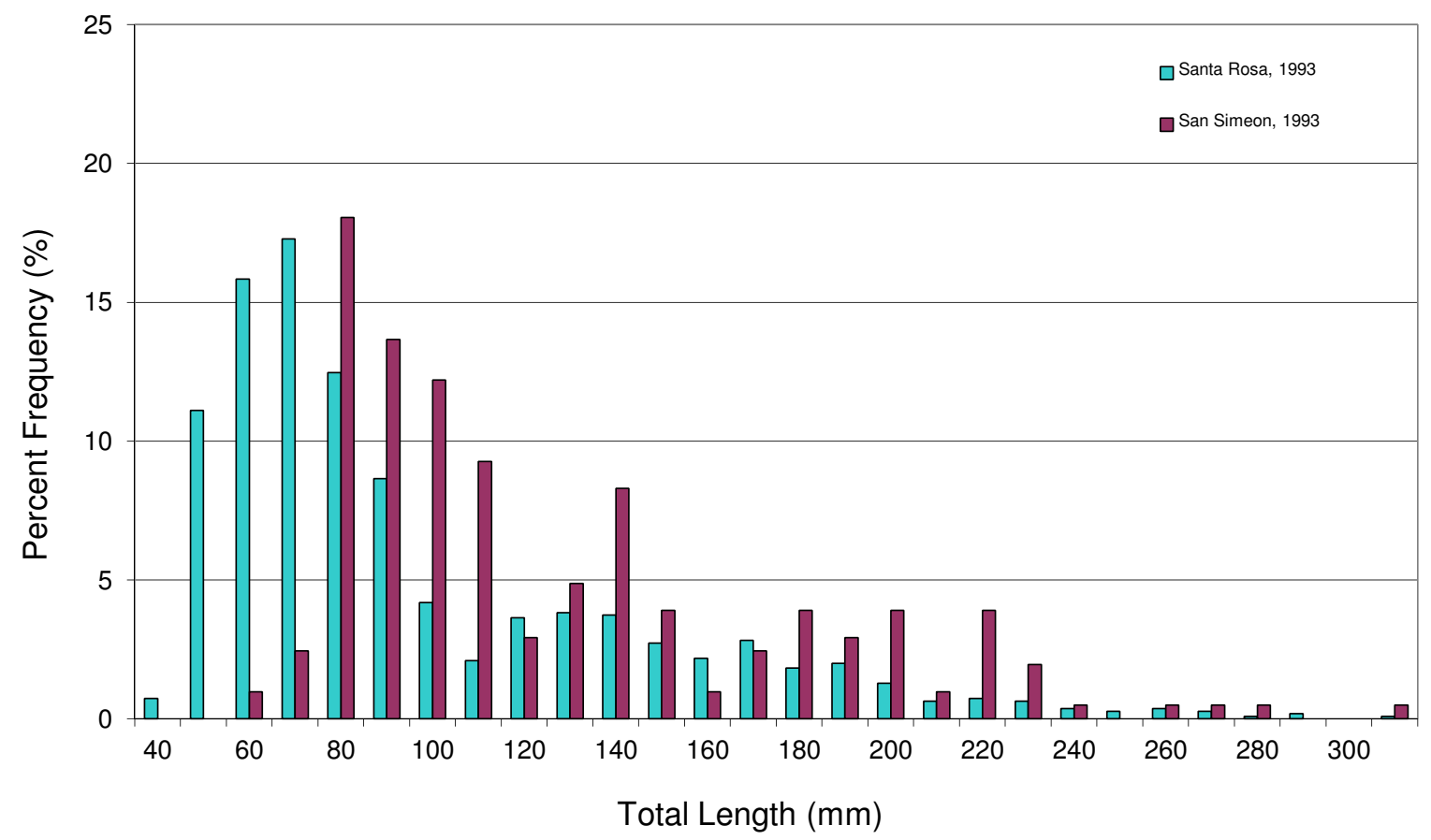

Figure 34. The percent frequency distribution of total lengths of steelhead electrofished from San Simeon $(\mathrm{N}=205)$ and Santa Rosa $(\mathrm{N}=1099)$ Creeks in 1993. 


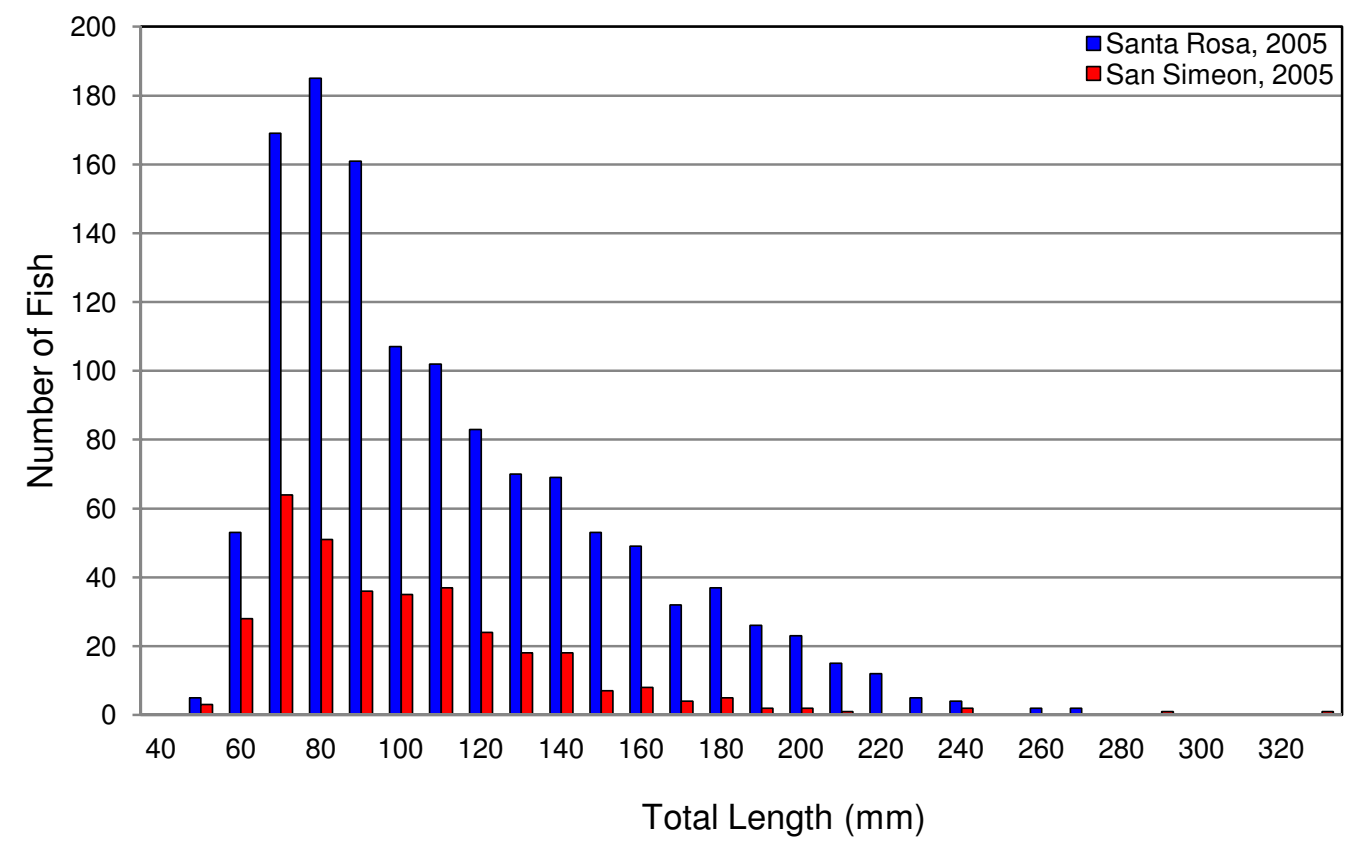

Figure 35. Total length distribution of steelhead electrofished from San Simeon ( $N=347)$ and Santa Rosa $(\mathrm{N}=1264)$ Creeks in 2005.

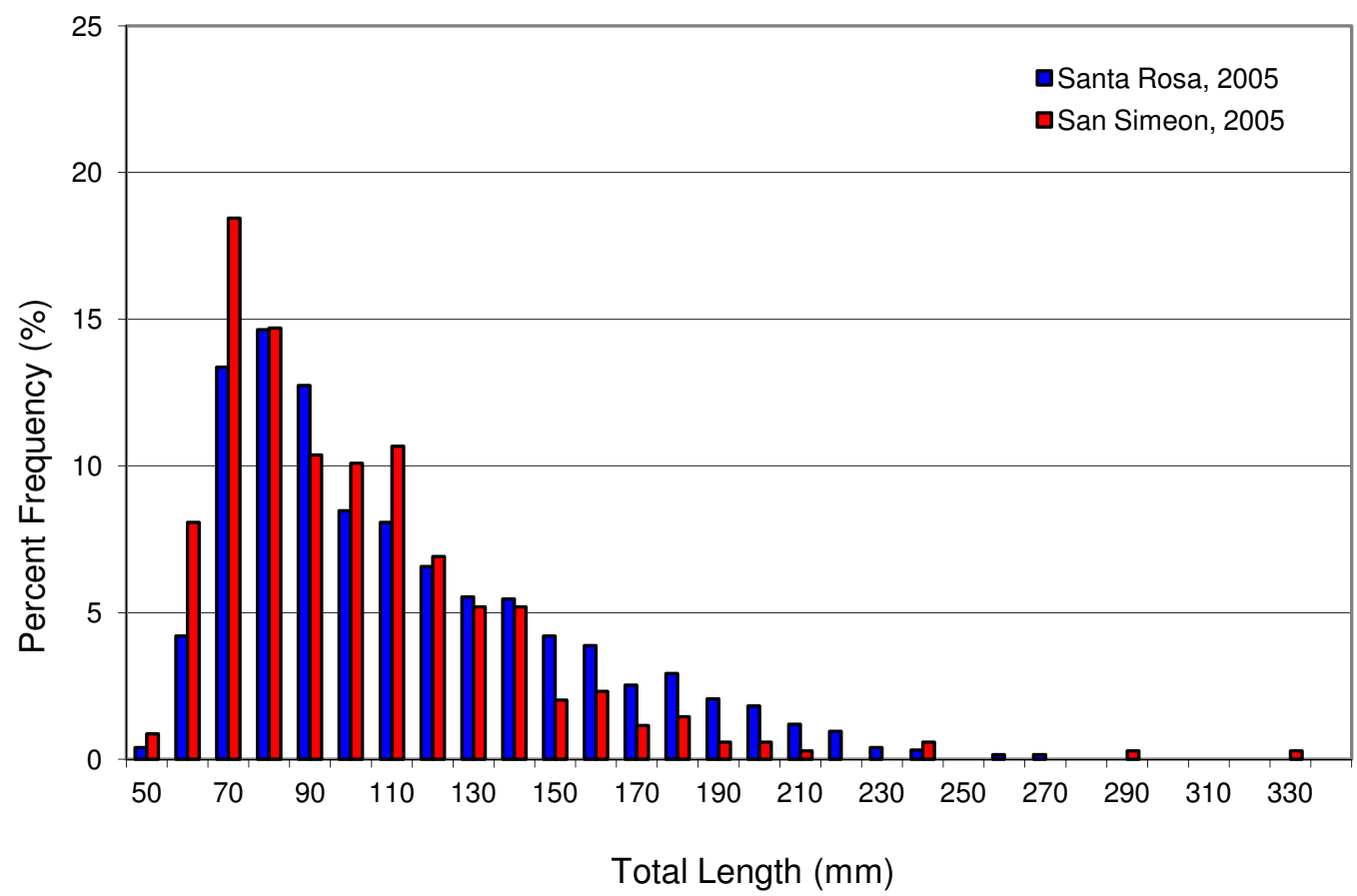

Figure 36. The percent frequency distribution of total lengths of steelhead electrofished from San Simeon $(\mathrm{N}=347)$ and Santa Rosa $(\mathrm{N}=1264)$ Creeks in 2005. 


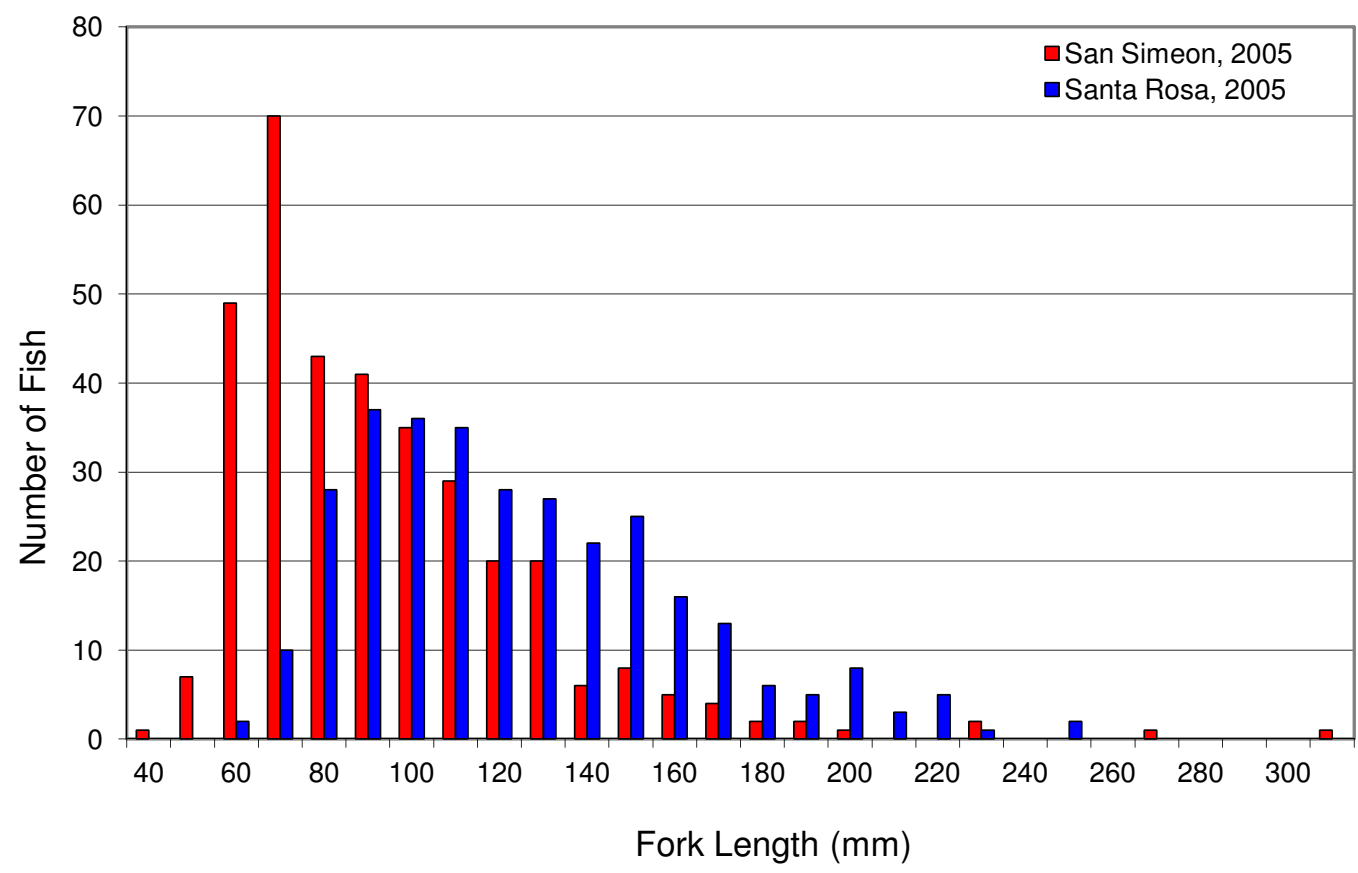

Figure 37. Fork length distribution of steelhead electrofished from San Simeon ( $N=347)$ and Santa Rosa $(\mathrm{N}=309)$ Creeks in 2005.

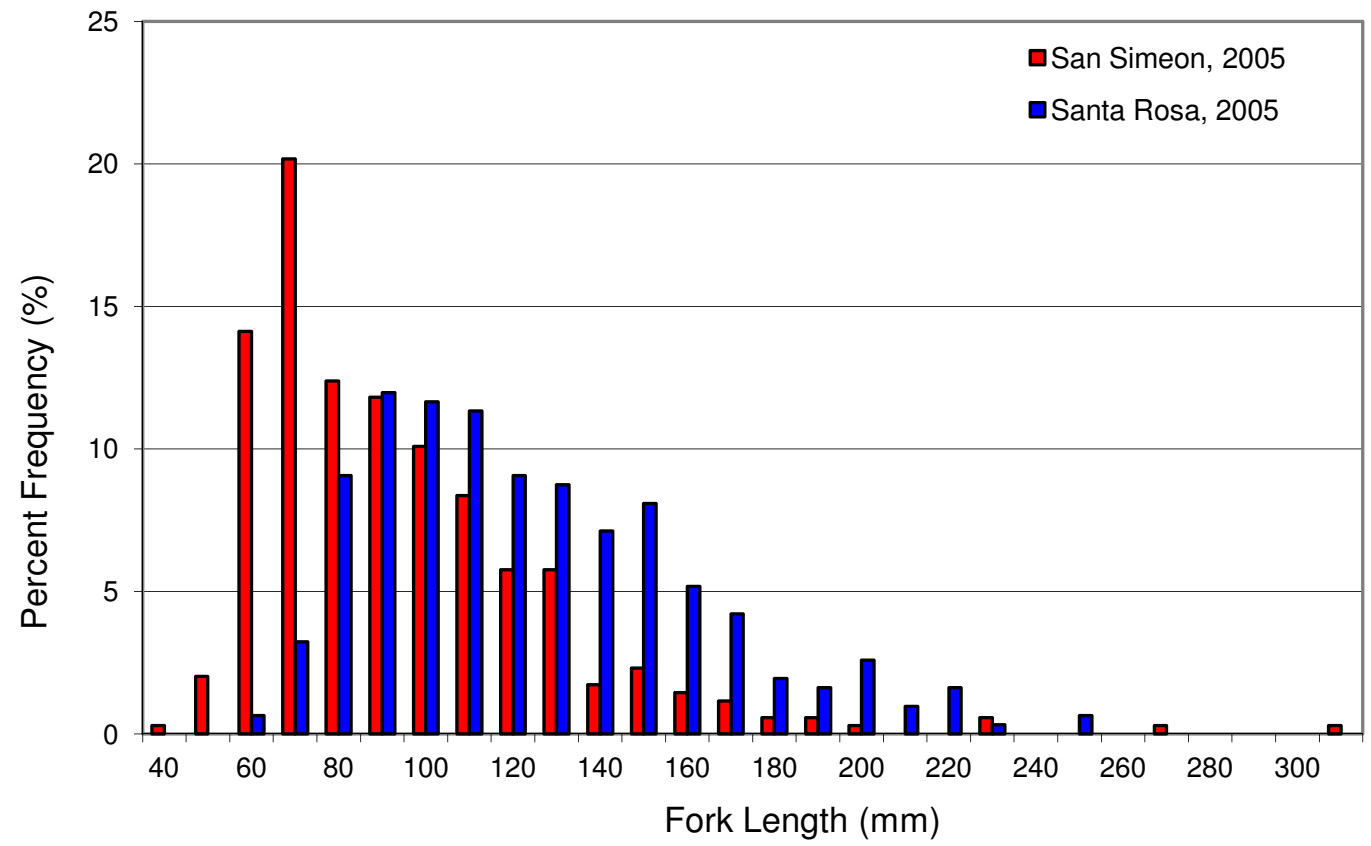

Figure 38. Percent frequency distribution of fork length of steelhead electrofished from San Simeon ( $\mathrm{N}=347)$ and Santa Rosa Creeks $(\mathrm{N}=309)$ in 2005. 


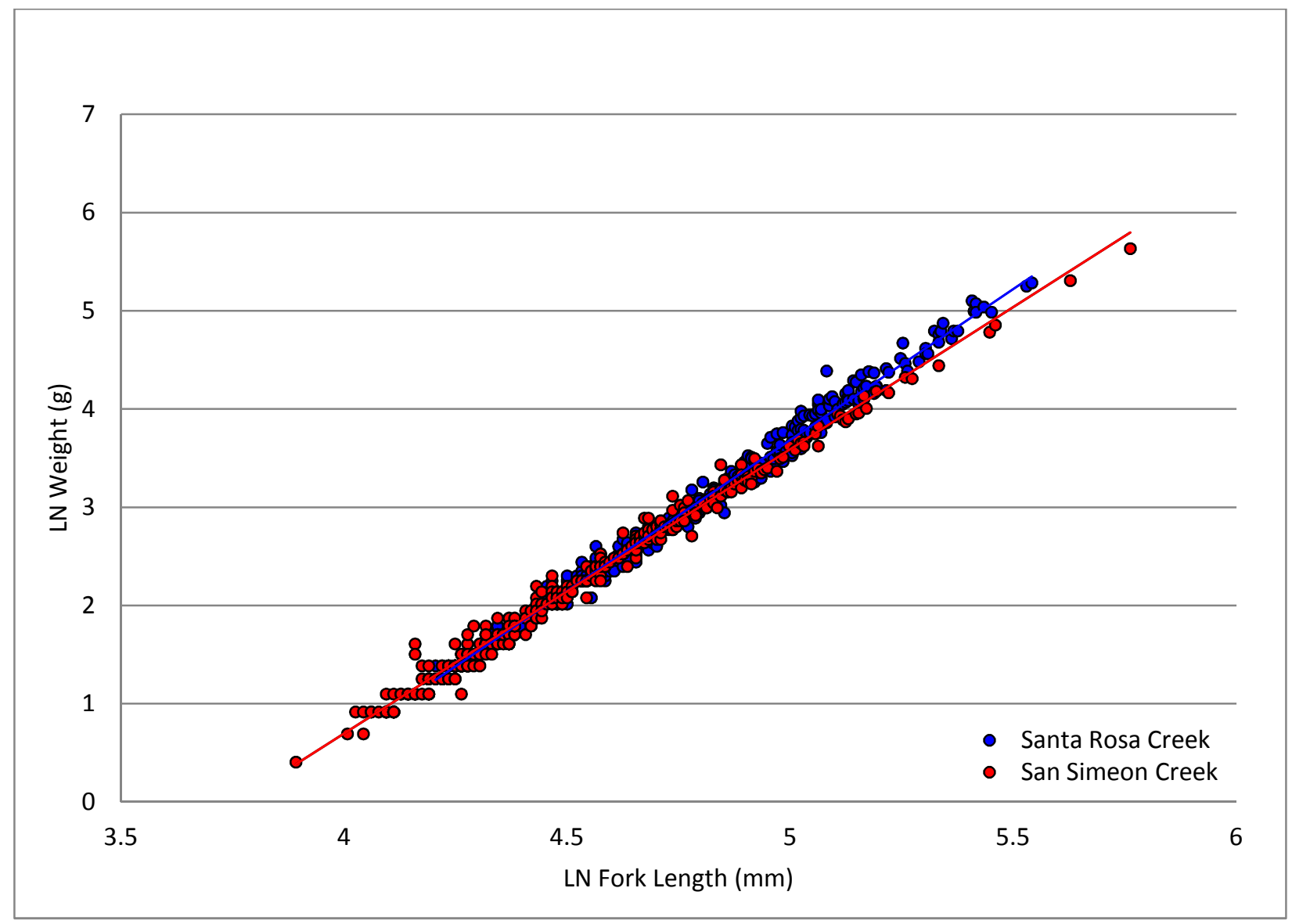

Figure 39. Scatter plot/regression analysis fork length and weight of steelhead electrofished on San

Simeon Creek $\left(N=344, W=-10.89+2.896 F L, R^{2}=0.989\right)$ and Santa Rosa Creek $(N=309, W=-11.67+$ 3.071 FL, $\left.R^{2}=0.988\right)$ in 2005. 


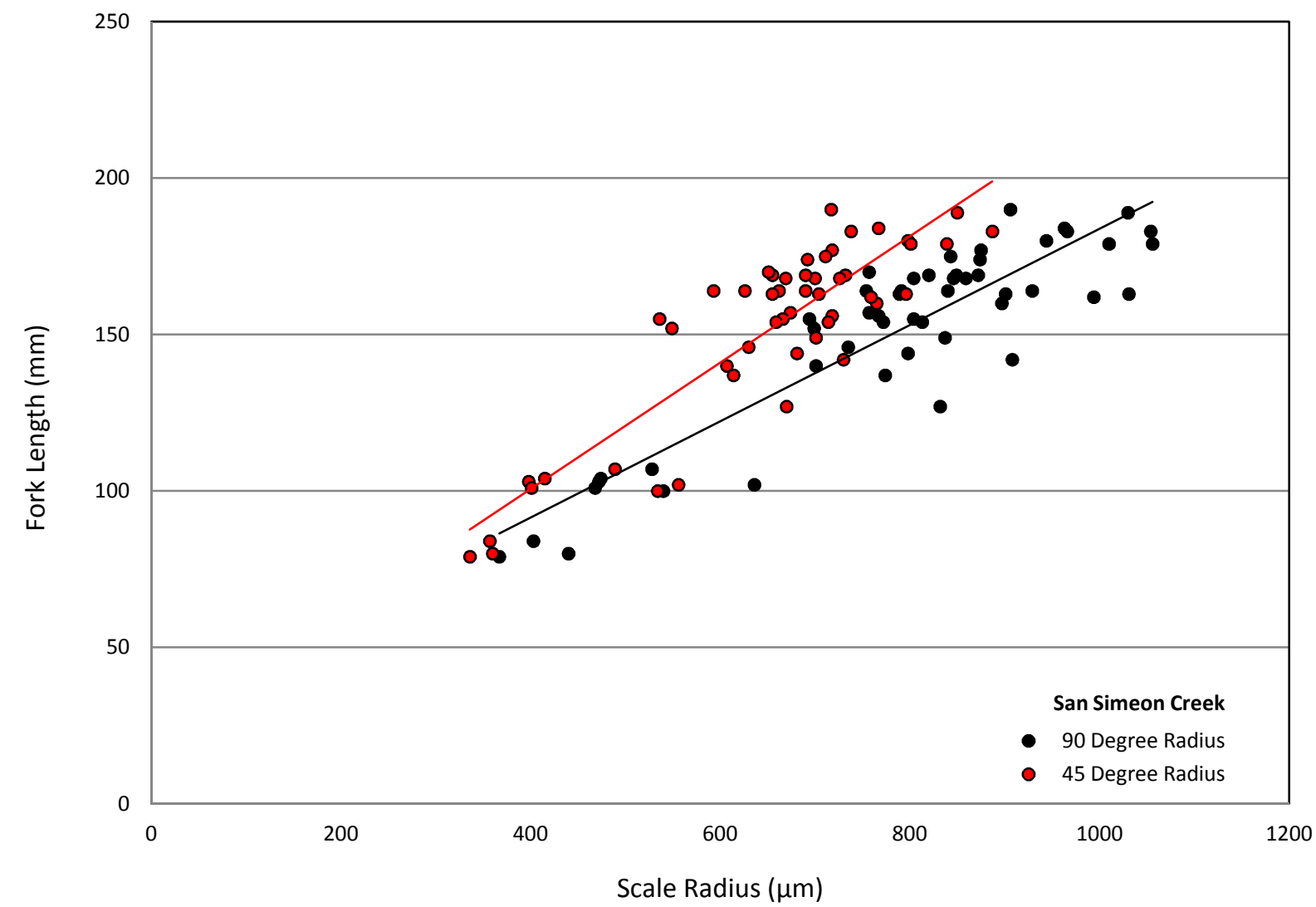

Figure 40. Scatter plot/regression analysis of scale radius measurements at the 90 and 45 degree angles versus fork length for age $0+, 1+, 2+$ steelhead caught on San Simeon Creek, 2005. N=50 (age 3+ fish not included). $90^{\circ}$ radius: $F L=29.94+0.1538$ SR. $R^{2}=0.807$. Correlation: $r=0.899, p<0.0001 .45^{\circ}$ radius: $F L=19.77+0.2019 S R . R^{2}=0.775$. Correlation: $r=0.880, p<0.0001$. 


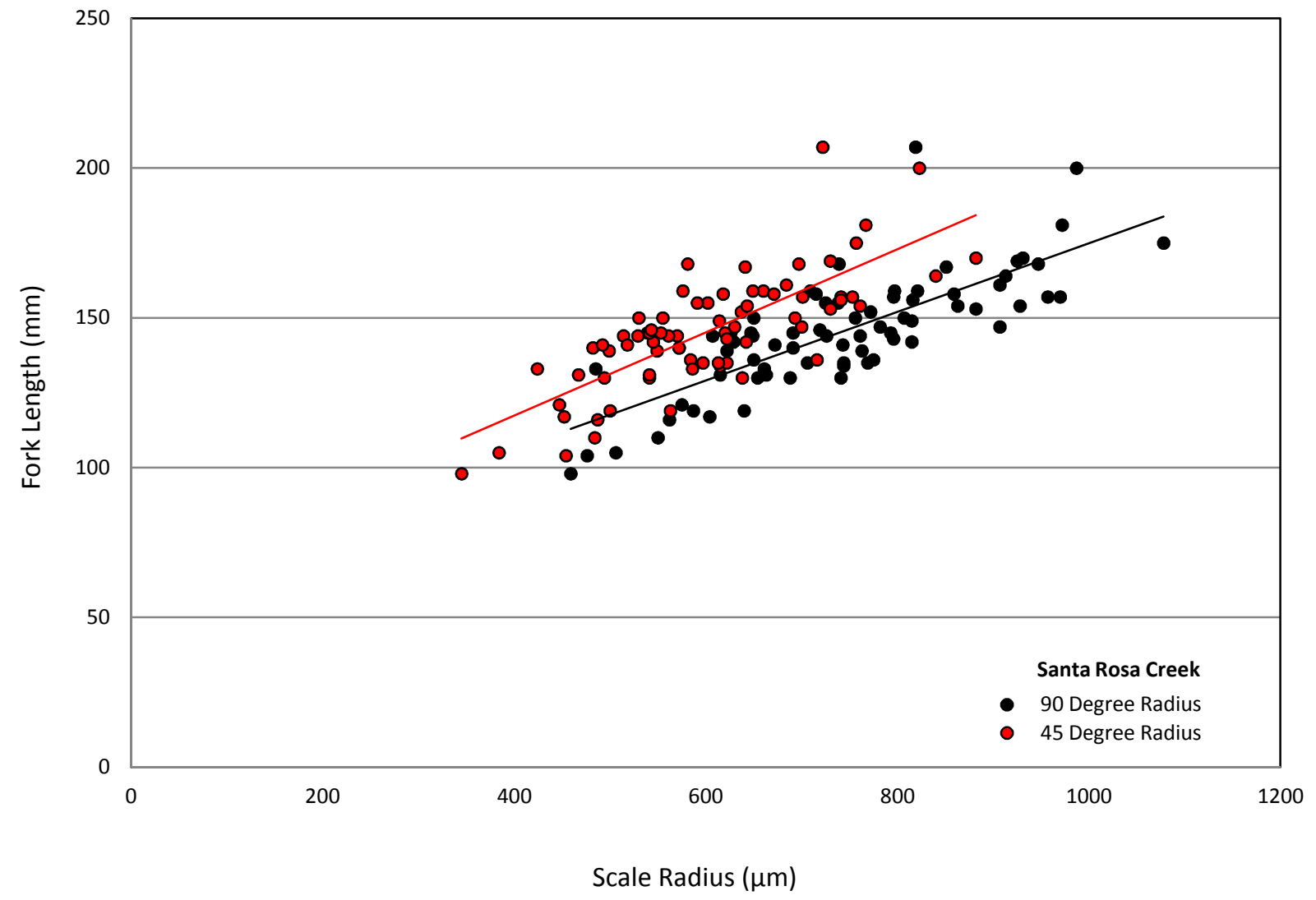

Figure 41. Scatterplot/regression analysis of scale radius measurements at the 90 and 45 angles versus fork length for and 1+ and 2+ steelhead caught on Santa Rosa Creek, 2005. N=72 (not including aged fish with no scale measurements). 90 degree: $F L=60.37+0.1145$ SR. $R^{2}=0.616$. Correlation: $r=0.785$, $p<0.0001 .45$ degree: $F L=61.89+0.1387$ SR. $R^{2}=0.592$. Correlation: $r=0.769, p<0.0001$. 


\section{Literature Cited}

Adobe Systems Incorporated (Producer). (2007). Photoshop CS3 Extended, (Version 10.0) [Computer software]. San Jose, CA.

Anderson, R. O., and S. J. Gutreuter. 1983. Length, Weight, and Associated Structural Indices. In L.A. Neilsen and D.L. Johnson (Eds.), Fisheries Techniques (pp. 283300). Bethesda, Maryland: American Fisheries Society.

Becker, G. S., K. M. Smetak, D. A. Asbury. 2010. Southern Steelhead Resources Evaluation: Identifying Promising Locations for Steelhead Restoration in Watersheds South of the Golden Gate. Cartography by D. A. Asbury. Center for Ecosystem Management and Restoration. Oakland, CA. [Electronic version] Retrieved November 6, 2011. http://www.opc.ca.gov/webmaster/ftp/project_pages/salmon and steelhead/CE MAR/Southern_Steelhead Resources Evaluation.pdf

Behnke, R. J. 1992. Native Trout of Western North America. Bethesda, Maryland: American Fisheries Society.

Bond, M. H. 2006. Importance of Estuarine Rearing to Central California Steelhead (Oncorhynchus mykiss) Growth and Marine Survival. Unpublished Master's Thesis, University of California, Santa Cruz.

Bond, M. H., S. A. Hayes, C. V. Hanson, \& MacFarlane, R. B. 2008. Marine survival of steelhead (Oncorhynchus mykiss) enhanced by a seasonally closed estuary. Can. J. Fish. Aquat. Sci. 65:2242-2252. 
Boughton, D. A., M. Gibson, R. Yedor, and E. Kelly. 2007. Stream temperature and the potential growth and survival of juvenile Oncorhynchus mykiss in a southern California creek. Freshwater Biology. 52: 1353-1364.

Boughton, D.A., P.B. Adams, E. Anderson, C. Fusaro, E. Keller, E. Kelley, L. Lentsch, J. Nielsen, K. Perry, H. Regan, J. Smith, C. Swift, L. Thompson, and F. Watson. 2006. Steelhead of the South-Central/Southern California Coast: Population Characterization for Recovery Planning. NOAA Technical Memorandum NMFS. 123 pp. [Electronic version]. Retrieved May 21, 2009.

http://swfsc.noaa.gov/publications/FED/00842.pdf

Briggs, J. C. 1953. The Behavior and Reproduction of Salmonid Fishes in a Small Coastal Stream. Calif. Dept. Fish Game, Fish Bull. 94.66 pp.

Bureau of Reclamation. 2001, revised reprint. Water Measurement Manual, third edition. United States Department of the Interior. Washington, DC. [Electronic version]. Retrieved December 9, 2010. http://www.usbr.gov/pmts/hydraulics lab/pubs/wmm/

Busby, P. J., T. C. Wainwright, G. J. Bryant, L. J. Lierheimer, R. S. Waples, F. W. Waknitz, \& I. V. Lagimarsino. 1996. Status Review of West Coast Steelhead from Washington, Idaho, Oregon, and California. NOAA Technical Memorandum NMFS-NWFSC-27. [Electronic version]. Retrieved May 20, 2009. http://www.nwfsc.noaa.gov/publications/techmemos/tm27/tm27.htm.

Coggins, Lewis G., Jr. 1994. Precision of Ages Estimated from Scales for Rainbow Trout in Bristol Bay, Alaska. Fishery Data Series No. 94-26Alaska Department of Fish and Game. [Electronic version]. Retrieved March 5, 2009. 
http://www.sf.adfg.state.ak.us/FedAidPDFs/FDS94-26.PDF.

Duff, Timothy. 2007. Santa Rosa Creek Watershed Enhancement Plan San Luis Obispo County. Coastal Conservancy. [Electronic version]. Retrieved June 20, 2008.

http://www.coastalconservancy.ca.gov/sccbb/0703bb/0703Board13D_Santa_Ros a Creek.pdf.

Flosi, G., S. Downie, J. Hopelain, M. Bird, R. Coey, and B. Collins. 1998. California Salmonid Stream Habitat Restoration Manual, 3rd edition. California Department of Fish and Game, Sacramento, California.

Froese, R. 2006. Cube law, condition factor and weight-length relationships: history, meta-analysis and recommendations. J. Appl. Ichthyol. 22: 241-253.

Gobalet, K. W. and T.L. Jones. 1995. Prehistoric Native American Fisheries of the Central California Coast. Transactions of the American Fisheries Society. 124: 813-823.

Hayes, S. A., M. H. Bond, C. V. Hanson, E. V. Freund, J. J. Smith, E. C. Anderson, A. J. Ammann, \& R. B. MacFarlane. 2008. Steelhead Growth in a Small Central Coast Watershed: Upstream and Estuarine Rearing Patterns. Transactions of the American Fisheries Society. 137:114-128.

Hoar, W.S. 1988. The Physiology of Smolting Salmonids. In Hoar, W. S., and D. J. Randall (Eds.), Fish Physiology. Vol. XI. The Physiology of Developing Fish Part B: Viviparity and Posthatching Juveniles (pp. 275-323). San Diego: Academic Press, Inc.

Horwath, S., S. Volan, S. Engblom, and T. Robinson. (2011, March). Insights gained 
from scale analysis of the endangered southern steelhead in the lower Santa Ynez River, Santa Barbara County. Poster session presented at the $45^{\text {th }}$ Annual Conference for the California Nevada Chapter of the American Fisheries Society and the $29^{\text {th }}$ Salmonid Restoration Conference of the Salmonid Restoration Federation, San Luis Obispo, CA.

Jearld, Ambrose, Jr. 1983. Age Determination. In L.A. Neilsen and D.L. Johnson (Eds.), Fisheries Techniques (pp. 301-324). Bethesda, Maryland: American Fisheries Society.

Lagler, K. F. 1956. Freshwater Fishery Biology. 2nd Ed. Dubuque, lowa: WM. C. Brown Company Publishers. 131-166 pp.

Loch, J.J., S.A. Leider, M.W. Chilcote, R. Cooper, and T.H. Johnson. 1988. Differences in yield, emigration-timing, size, and age structure of juvenile steelhead from two small western Washington streams. Calif. Fish and Game. 74(2): 106-118.

McEwan, D. and T. A. Jackson. 1996. Steelhead Restoration and Management Plan for California. California Department of Fish and Game. 246 pp.

Minitab Inc. (Producer). (2010). Minitab Statistical Software (Version 16) [Computer software]. State College, PA.

Moyle, P. B. 2002. Inland Fishes of California. London: University of California Press, Ltd. 271-282 pp.

Moyle, P. B, J. A. Israel, S. E.Purdy. 2008. Salmon, Steelhead, and Trout in California: Status of an Emblematic Fauna. A report commissioned by California Trout. [Electronic version]. Retrieved February 17, 2012. 
http://watershed.ucdavis.edu/pdf/SOS-Californias-Native-Fish-Crisis-FinalReport.pdf.

Nash, R.D.M., A.H. Valencia, and A.J. Geffen. 2006. The Origin of Fulton's Condition Factor- Setting the Record Straight. Fisheries. 31 (5): 236-238.

National Marine Fisheries Service (NMFS), Southwest Fisheries Science Center. 2006. Steelhead of the South-Central/Southern California Coast: Population Characterization for Recovery Planning. NOAA Technical Memorandum NMFS. $123 \mathrm{pp}$.

National Marine Fisheries Service (NMFS), Southwest Region. 2007. 2007 Federal Recovery Outline for the Distinct Population Segment of South-Central California Coast Steelhead. Outline. 42 pp.

Nelson, Jennifer. 1994. Summary of Steelhead Population and Habitat Sampling Santa Rosa Creek, San Luis Obispo County, 1993. Calif. Dept. Fish Game, Region 3 Report. 82 pp + app.

Nelson, Jennifer. 1995. Summary of Steelhead Population and Habitat Sampling San Simeon Creek, San Luis Obispo County, 1993. Calif. Dept. Fish Game. 19 pp + app.

Nelson, Jennifer. 2005. Lagoon surveys of San Simeon and Santa Rosa Creeks. Unpublished data.

Nelson, Jennifer. Personal communication. 2008.

Nelson, Jennifer. 2009a. Stream Habitat Inventory Report, San Simeon Creek. Calif. Dept. Fish Game. In preparation.

Nelson, Jennifer. 2009b. Stream Habitat Inventory Report, Santa Rosa Creek. 
Calif. Dept. Fish Game.

Nielson, L.A., \& D.L. Johnson, editors. 1983. Fisheries Techniques. American Fisheries Society: Bethesda, Maryland. 301-324 pp.

Platts, W. S. 1979. Livestock grazing and riparian/stream ecosystems- an overview. In Proceedings from the forum- grazing and riparian/stream ecosystems. Trout Unlimited Inc., Denver, Colorado, 94 pp.

Quinn, T. P. 2005. The Behavior and Ecology of Pacific Salmon and Trout. Seattle and London: University of Washington Press. 218-226 pp.

Railsback, S. F., and K. A. Rose. 1999. Bioenergetics modeling of stream trout growth: temperature and food consumption effects. Transactions of the American Fisheries Society. 128:241-256.

Reiser, D. W., \& T. C. Bjornn. 1979. Habitat requirements of anadromous salmonids. 54 pp. in W. R. Meehan, ed. Influence of Forest and Range Management on Anadromous Fish Habitat in Western North America. Pacific N.W. Forest and Range Exp. Sta. USDA For. Serv., Region 5, San Francisco, Calif. 77pp.

Rosenfeld, J., M. Porter, and E. Parkinson. 2000. Habitat factors affecting the abundance and distribution of juvenile cutthroat trout (Oncorhynchus mykiss) and coho salmon (Oncorhynchus kisutch). Can. J. Fish. Aquat. Sci. 57: 766-774.

Shapovalov, L., and A.C. Taft. 1954. The life histories of steelhead rainbow trout (Salmo gairdneri gairdneri) and silver salmon (Oncorhynchus kisutch). Calif. Dept. Fish Game, Fish Bull. 98. 375 pp.

Sogard, S. M., T. H. Williams, and H. Fish. 2009. Seasonal patterns of abundance, growth, and site fidelity of juvenile steelhead in a small coastal California stream. 
Transactions of the American Fisheries Society. 138: 3, 549-563.

Spina, A. 2003. Habitat associations of steelhead trout near the southern extent of their range. California Fish and Game. 89(2): 81-95.

Telegraph Tribune Newspaper. Microfiche. 1992-1993. Rainfall amounts. Accessed April 11, 2009.

The Tribune Newspaper. Microfiche. 2004-2005. Rainfall amounts. Accessed April 11, 2009.

Tesch, F.W. 1968. Age and growth. In: Methods for Assessment of fish production in fresh waters. W.E. Ricker (Ed.). Blackwell Scientific Publications, Oxford. 93$123 \mathrm{pp}$.

Titus, R.G., D.C. Erman, and W.M. Snider. 2010. History and Status of Steelhead in California Coastal Drainages South of San Francisco Bay. In preparation.

Thorpe, J.E. 1998. Salmonid Life History Evolution as a Constraint on Marine Stock Enhancement. Bulletin of Marine Science. 62(2): 465-475.

Wedemeyer, G. A., R. L. Saunders, and W. C. Clarke. 1980. Environmetnal Factors Affecting Smoltification and Early Marine Survival of Anadromous Salmonids. Mar. Fish. Rev. 42(6): 1-14.

Wilson, Karen. Stream Habitat 2.0.16, a Visual Basic data entry program. [Computer software]. Accessed December 7, 2006. Pacific States Marine Fisheries Commission and California Department of Fish and Game, Sacramento, California.

Zippin, C. 1958. The Removal Method of Population Estimation. The Journal of Wildlife Management. 22(1): 82-90. 
